\title{
Idaho National Laboratory \\ Comprehensive Land Use and Environmental Stewardship report
}

August 2011

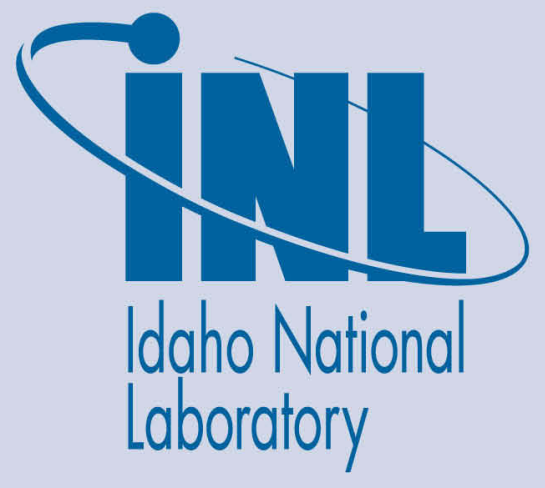

The INL is a U.S. Department of Energy National Laboratory operated by Battelle Energy Alliance 


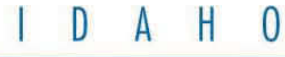
$\begin{array}{lllllllll}N & A & T & \text { I } & 0 & N & A & \text { L }\end{array}$
L A
$\begin{array}{llllllll} & 0 & R & A & T & 0 & R & Y\end{array}$

\section{Idaho Wational Lehoratory Eormprehensive Land Use and Envitonnenteal stewardshp Report}

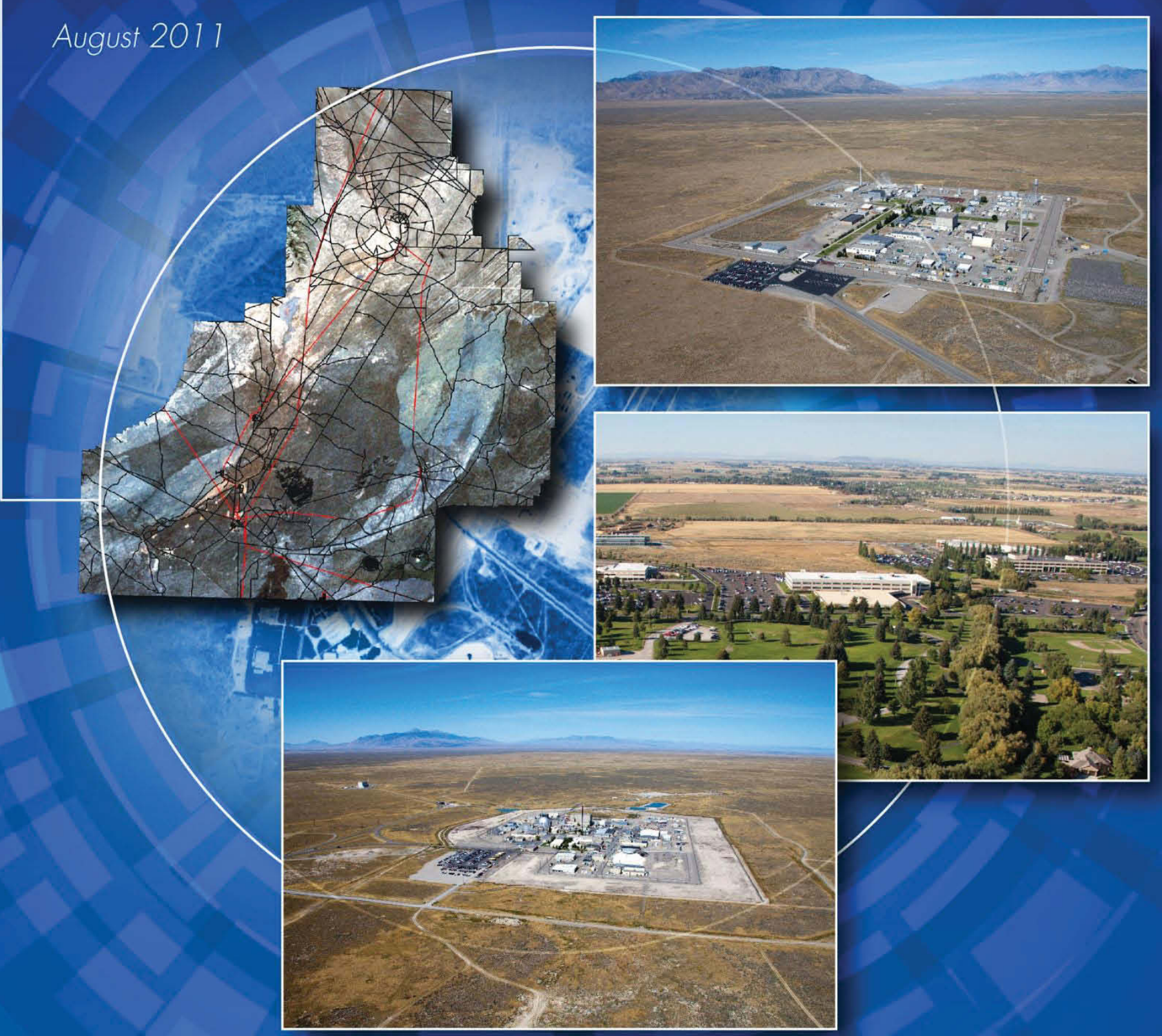

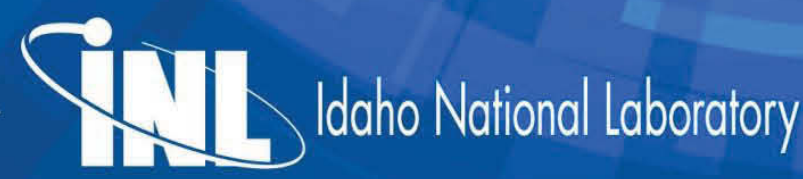




\section{DISCLAIMER}

This information was prepared as an account of work sponsored by an agency of the U.S. Government. Neither the U.S. Government nor any agency thereof, nor any of their employees, makes any warranty, expressed or implied, or assumes any legal liability or responsibility for the accuracy, completeness, or usefulness, of any information, apparatus, product, or process disclosed, or represents that its use would not infringe privately owned rights. References herein to any specific commercial product, process, or service by trade name, trade mark, manufacturer, or otherwise, does not necessarily constitute or imply its endorsement, recommendation, or favoring by the U.S. Government or any agency thereof. The views and opinions of authors expressed herein do not necessarily state or reflect those of the U.S. Government or any agency thereof. 
INL/EXT-05-00726

Revision 1

\title{
Idaho National Laboratory Comprehensive Land Use and Environmental Stewardship Report
}

\author{
Prepared by \\ INL Campus Development Office \\ North Wind, Inc.
}

August 2011

Idaho National Laboratory

Infrastructure Optimization, Integration, and Planning

Idaho Falls, Idaho 83415

http://www.inl.gov

Prepared for the

U.S. Department of Energy

Office of Nuclear Energy

Under DOE Idaho Operations Office

Contract DE-AC07-05ID14517 



\section{EXECUTIVE SUMMARY}

Land and facility use planning and decisions at the Idaho National Laboratory (INL) Site are guided by a comprehensive site planning process in accordance with Department of Energy Policy 430.1, "Land and Facility Use Policy," that integrates mission, economic, ecologic, social, and cultural factors. The INL Ten-Year Site Plan, prepared in accordance with Department of Energy Order 430.1B, "Real Property Asset Management," outlines the vision and strategy to transform INL to deliver world-leading capabilities that will enable the Department of Energy to accomplish its mission. Land use planning is the overarching function within real property asset management that integrates the other functions of acquisition, recapitalization, maintenance, disposition, real property utilization, and long-term stewardship into a coordinated effort to ensure current and future mission needs are met.

All land and facility use projects planned at the INL Site are considered through a formal planning process that supports the Ten-Year Site Plan. This Comprehensive Land Use and Environmental Stewardship Report describes that process. The land use planning process identifies the current condition of existing land and facility assets and the scope of constraints across INL and in the surrounding region. Current land use conditions are included in the Comprehensive Land Use and Environmental Stewardship Report and facility assets and scope of constraints are discussed in the Ten-Year Site Plan. This report also presents the past, present, and future uses of land at the INL Site that are considered during the planning process, as well as outlining the future of the INL Site for the 10, 30, and 100-year timeframes. 


\section{CONTENTS}

EXECUTIVE SUMMARY

ACRONYMS ix

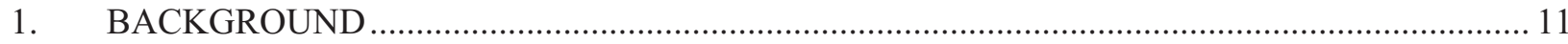

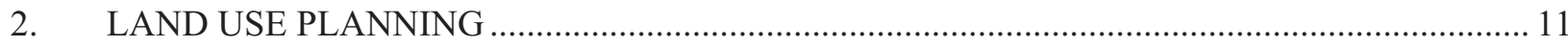

2.1 Department of Energy Policy 430.1 and Department of Energy Order 430.1B ................. 13

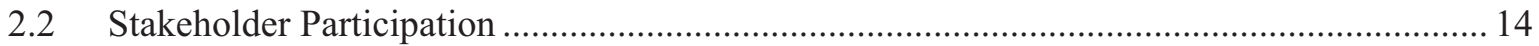

2.3 Assumptions and Environmental Considerations …...................................................... 14

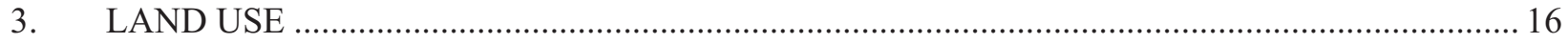

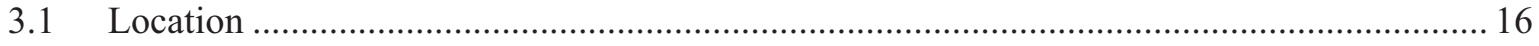

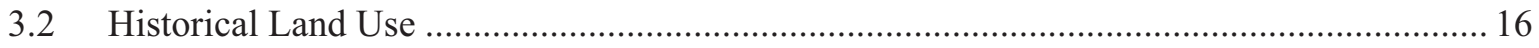

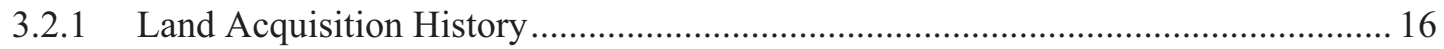

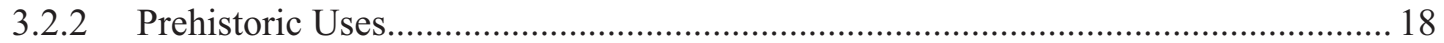

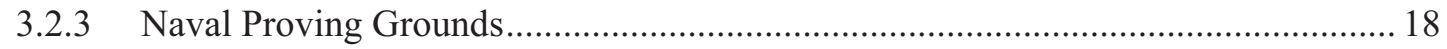

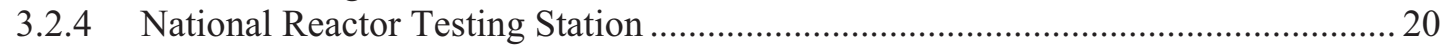

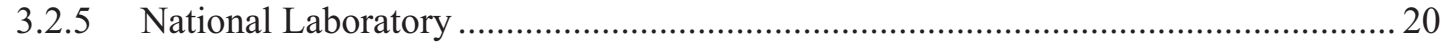

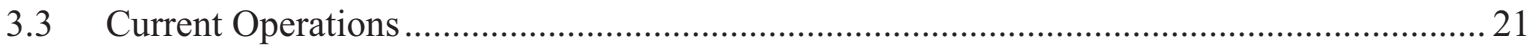

3.3.1 Regulatory Agreements and Permits............................................................... 21

3.3.2 Comprehensive Environmental Response, Compensation, and Liability Act

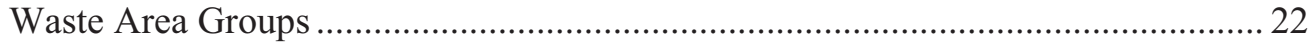

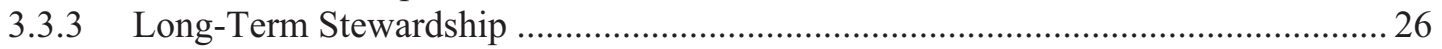

3.3.4 Non-Comprehensive Environmental Response, Compensation, and Liability Act Environmental Management Operations ..........................................................22

3.3.5 Department of Energy Office of Nuclear Energy Onsite Operations ........................ 29

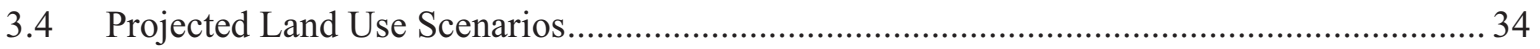

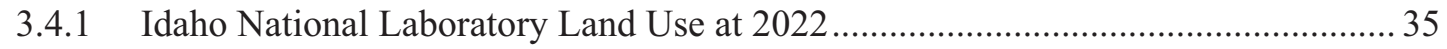

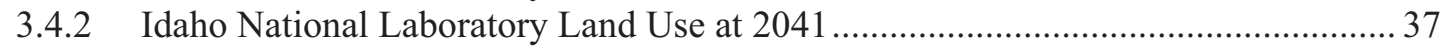

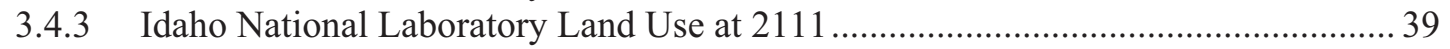

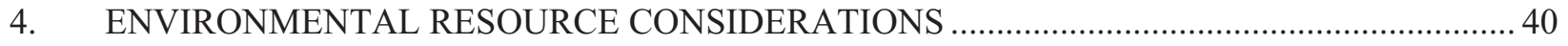

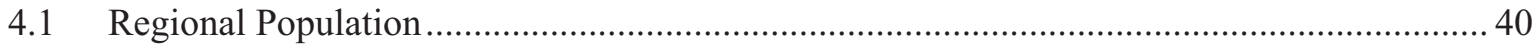

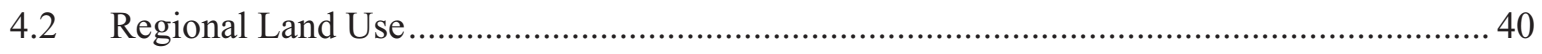

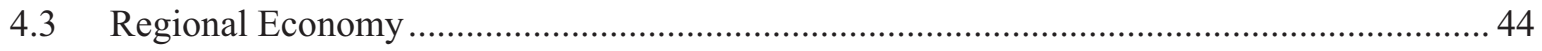




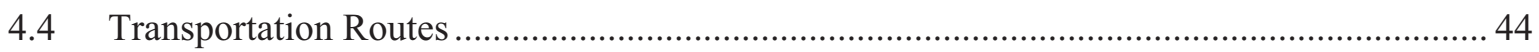

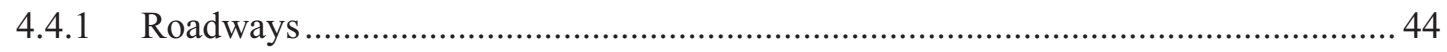

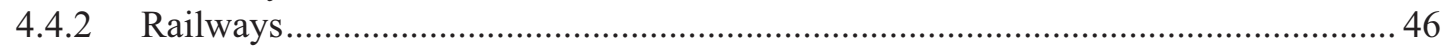

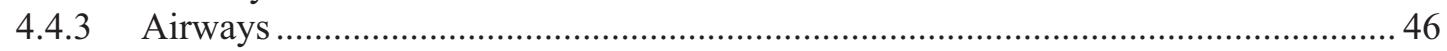

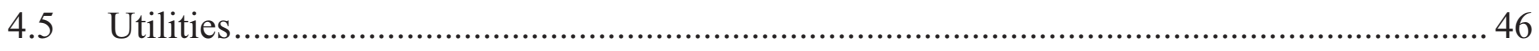

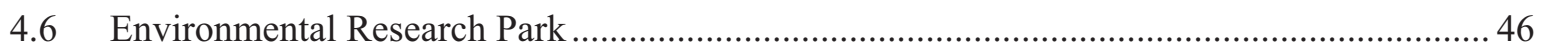

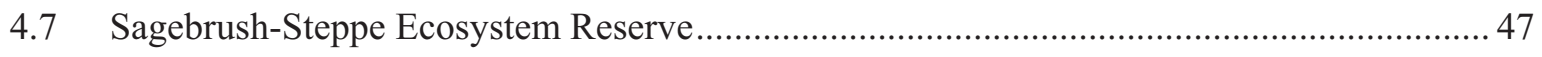

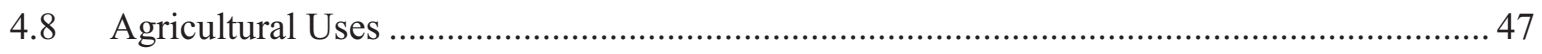

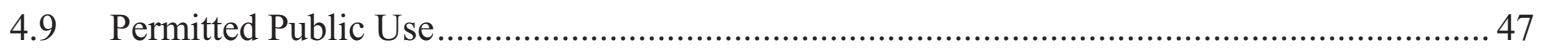

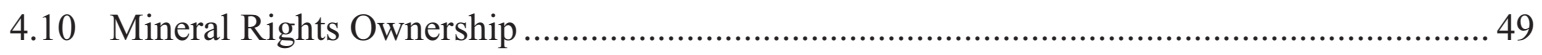

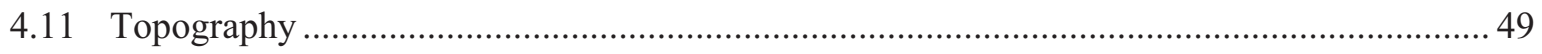

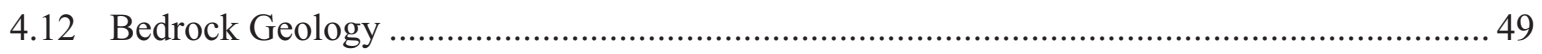

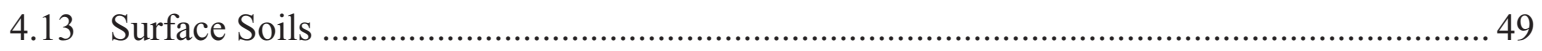

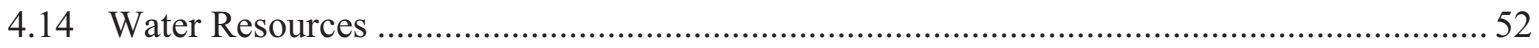

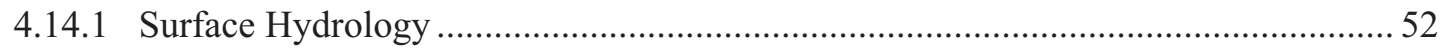

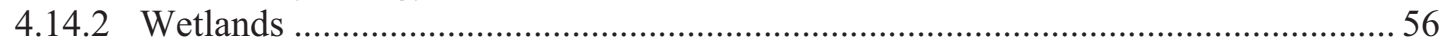

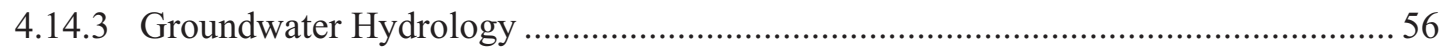

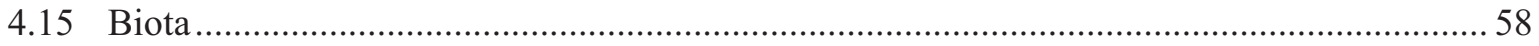

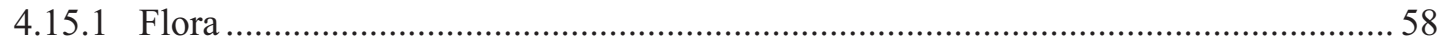

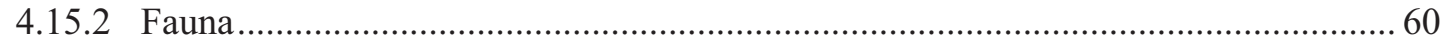

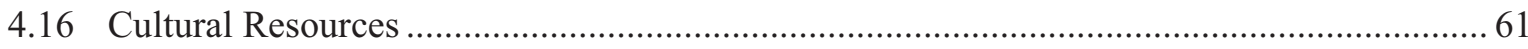

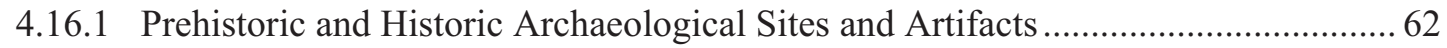

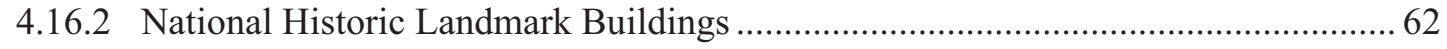

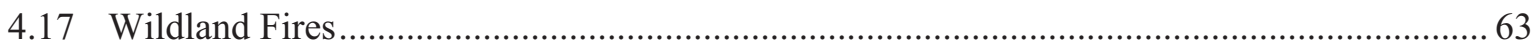

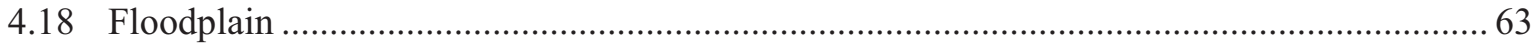

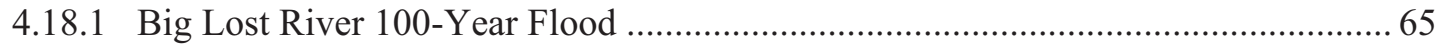

4.18.2 Big Lost River Floods with Return Periods Greater than 100 Years ........................ 65

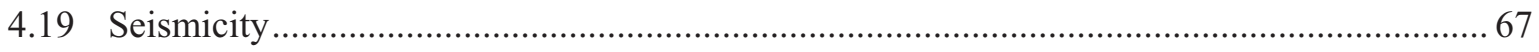

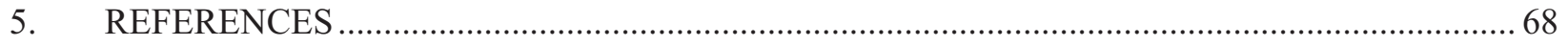




\section{FIGURES}

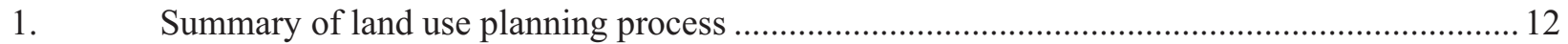

2. Idaho National Laboratory Site location in the State of Idaho .............................................. 17

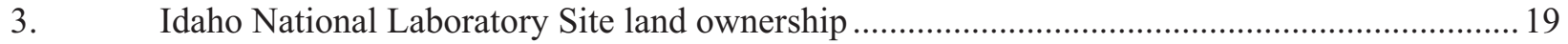

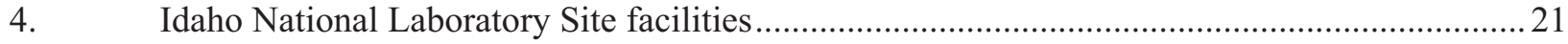

5. Idaho National Laboratory institutionally controlled areas ................................................ 27

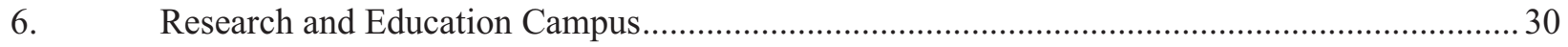

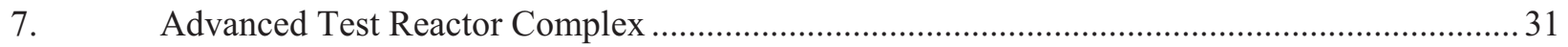

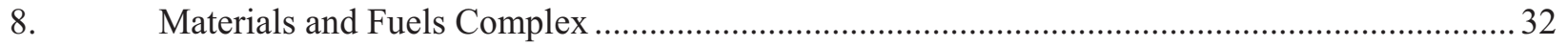

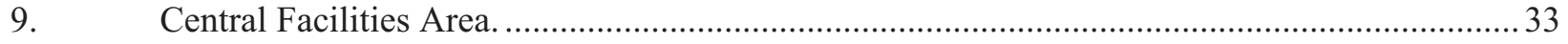

10. Idaho Nuclear Technology and Engineering Center............................................................... 34

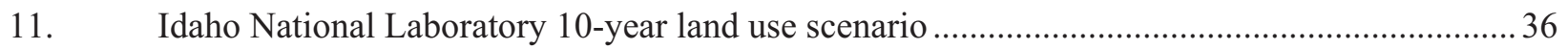

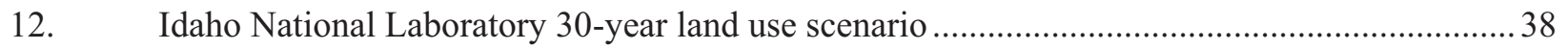

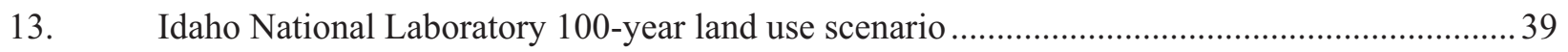

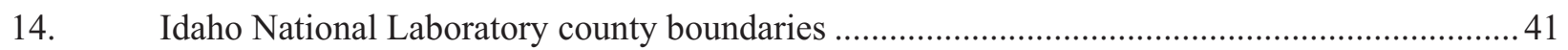

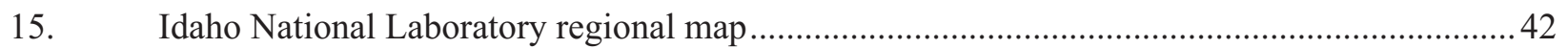

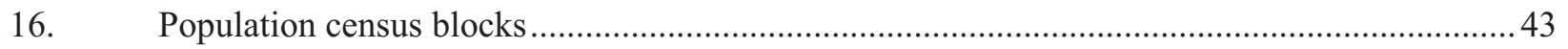

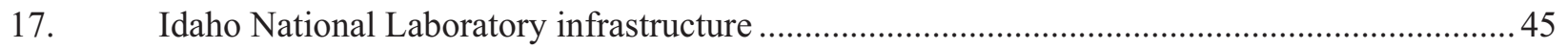

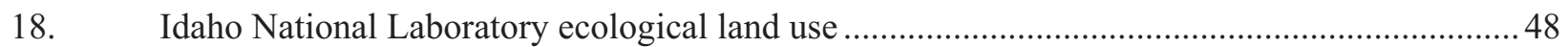

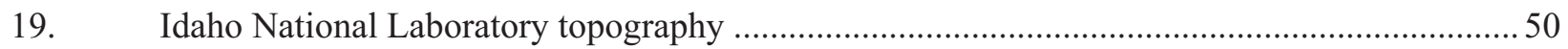

20. Idaho National Laboratory bedrock geology ..................................................................... 51

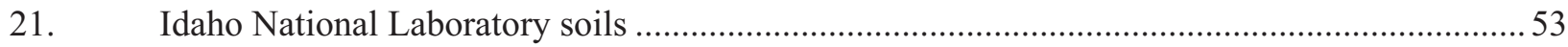

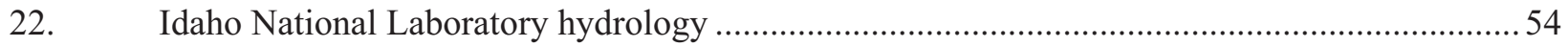

23. Idaho National Laboratory groundwater contours............................................................... 57

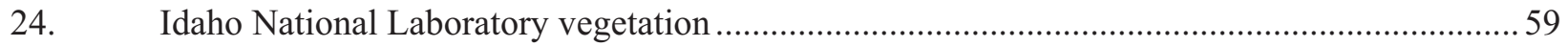

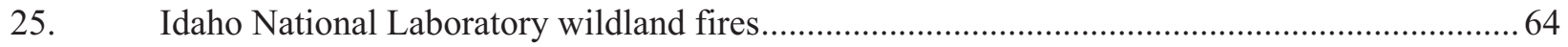




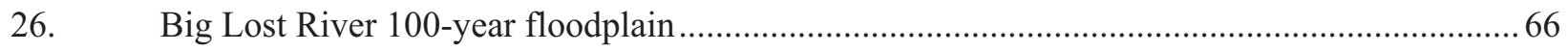

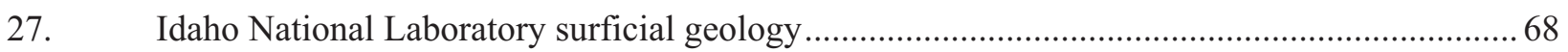

\section{TABLES}

1. Watersheds and aquifers directly associated with the Idaho National Laboratory Site..............55 


\section{ACRONYMS}

AEC Atomic Energy Commission

ARA Auxiliary Reactor Area

ATR Advanced Test Reactor

BLM Bureau of Land Management

CERCLA Comprehensive Environmental Response, Compensation, and Liability Act

CFA Central Facilities Area

CITRC Critical Infrastructure Test Range Complex

D\&D decontamination and decommissioning

DOE U.S. Department of Energy

DOE-EM U.S. Department of Energy Office of Environmental Management

DOE-ID U.S. Department of Energy Idaho Operations Office

DOE-NE U.S. Department of Energy Office of Nuclear Energy

EBR Experimental Breeder Reactor

FFA/CO Federal Facility Agreement and Consent Order

INL Idaho National Laboratory

INTEC Idaho Nuclear Technology and Engineering Center

MFC Materials and Fuels Complex

NRF Naval Reactor Facility

NRTS National Reactor Testing Station

R\&D research and development

REC Research and Education Campus

RWMC Radioactive Waste Management Complex

SNF spent nuclear fuel

TAN Test Area North

TYSP Ten-Year Site Plan

USFWS U.S. Fish and Wildlife Service

WAG Waste Area Group 


\section{Idaho National Laboratory Comprehensive Land Use and Environmental Stewardship Report}

1. BACKGROUND

The land that comprises the Idaho National Laboratory (INL) Site has experienced a long and varied history. Located in a high desert area (about 5,000 ft elevation) known as the Snake River Plain, the INL Site has served both prehistoric and modern man. For thousands of years, prehistoric Native American populations, consisting of nomadic hunter/gathers, moved through the area seasonally as part of their annual subsistence round, exploiting available wildlife and plant resources. Modern use of this land changed in 1943 when the site was selected as an artillery test range in support of World War II military activities and was referred to as the Naval Proving Ground. The National Reactor Testing Station (NRTS) was later created in 1949 when the Atomic Energy Commission (AEC) selected the Naval Proving Ground site as its location to perform safety tests on a variety of nuclear reactors. Over the years, 52 nuclear reactors were constructed and tested at the INL Site and thousands of experiments and tests were performed, resulting in production and accumulation of hazardous and radioactive materials.

Today INL is a science-based, multi-program national laboratory dedicated to supporting the U.S. Department of Energy (DOE) missions in nuclear and energy research, science, and national defense. The mission of INL is to ensure the nation's energy security with safe, competitive, and sustainable energy systems and unique national and homeland security capabilities. INL's vision is to be the preeminent nuclear energy laboratory with synergistic, world-class, multi-program capabilities and partnerships.

DOE's vision is that INL will

- Become the preeminent, internationally recognized nuclear energy research, development, and demonstration laboratory

- Become a major center for national security technology development and demonstration

- Become a multi-program national laboratory with world-class capabilities

- Foster academic, industry, government, and international collaborations to produce the investment, programs, and expertise needed to ensure the vision.

Ongoing operations at the INL Site include separate missions for DOE's Office of Environmental Management (DOE-EM) and Office of Nuclear Energy (DOE-NE) research and security. DOE-NE activities are generally focused on nuclear energy research, sustainable energy systems, and unique national and homeland security that will transform INL into the preeminent nuclear energy laboratory. DOE-NE activities are managed by Battelle Energy Alliance, acting on behalf of DOE as the INL landlord.

DOE-EM activities are generally focused on waste management of various hazardous and radioactive materials, spent nuclear fuel management, and environmental remediation of contaminated soils and groundwater sites, primarily from legacy projects at the INL Site. DOE-EM activities are currently carried out through the Idaho Cleanup Project that is managed by CH2M-WG Idaho, LLC for DOE-EM.

\section{LAND USE PLANNING}

The "Land and Facility Use Policy," DOE Policy 430.1, is a formal, integrated planning process that is used to identify an appropriate mix of land uses at each site and to provide guidance for future site development and reuse based on the shared long-term goals and objectives of DOE, INL, and its stakeholders. Under this planning process, DOE's land and facilities are to be holistically managed as a valuable national resource through integration of missions, ecology, economies, and cultural and social 
factors in a regional context. Land use planning is an adaptive and iterative process that includes regional considerations developed with stakeholder input.

Land use planning is the overarching function within real property asset management that integrates the other functions of acquisition, recapitalization, maintenance, disposition, real property utilization, and long-term stewardship into a coordinated effort to ensure current and future mission needs are met. To achieve their full potential, DOE sites are given, under the life-cycle asset management approach, the responsibility of tailoring the process to local conditions and to existing activities that impact planning for DOE's land and facility assets.

INL has tailored their land use planning process based on guidance in DOE Policy 430.1 and DOE Order 430.1B, "Real Property Asset Management." Briefly, all projects planned at INL are considered through a formal planning process (Figure 1). The planning process includes land use committees from both DOE-NE (through Battelle Energy Alliance) and the DOE Idaho Operations Office (DOE-ID). Requests are submitted to DOE-NE (via the campus development office), which uses a standard consideration process to look at mission goals, existing and past uses, resources of concern, and many other factors in relation to the requested project. The Facilities Information Management System database and Geographic Information System play an important role in this planning process because multiple data and information sources can be evaluated in detail when considering a project. The INL Land Use Committee, composed of individuals representing the interests of DOE-NE and DOE-EM, meets to consider the proposal and issues a recommendation to senior leadership, who make the final decision on the proposed project.

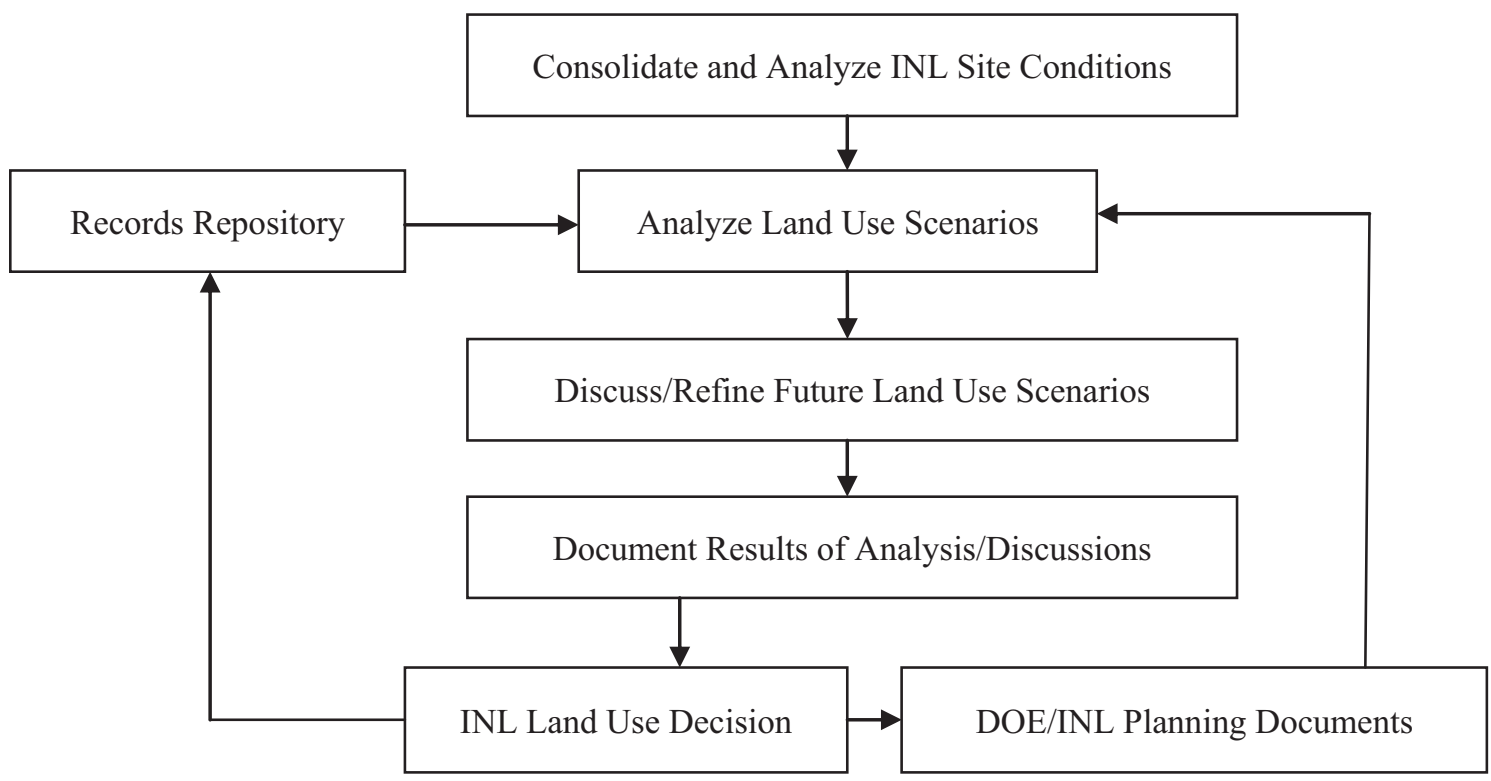

Figure 1. Summary of land use planning process.

Section 3 of this report presents the past, present, and future uses of land at INL that are considered during this planning process. Section 4 presents a number of resources that are considered during the planning process. The maps in Section 4 are presented for informational purposes only; detailed Geographic Information System layers would be used to produce site-specific maps for the proposed project area. 


\subsection{Department of Energy Policy 430.1 and Department of Energy Order 430.1B}

The planning process for each site will guide land and facility use decisions. INL produces a Ten-Year Site Plan (TYSP), in accordance with DOE Order 430.1B, which states that the results of real property asset site planning and performance must be documented in a TYSP that is kept current and covers a 10-year planning horizon. INL developed an initial TYSP in 2003 and updated it in 2008. The latest update, Idaho National Laboratory Ten-Year Site Plan for 2013 through 2022, ${ }^{1}$ outlines the vision and strategy to transform INL to deliver world-leading capabilities that will enable DOE-NE to accomplish its mission.

The latest update of the TYSP describes the strategy for accomplishing the long-term objective of transforming INL to meet DOE national nuclear research and development (R\&D) goals, as outlined in DOE strategic plans. These plans include the Nuclear Energy Research and Development Roadmap ${ }^{2}$ and the Facilities for the Future of Nuclear Energy Research: A Twenty-Year Outlook. ${ }^{3}$ The 2010 DOE-NE Roadmap established DOE-NE's principal mission as advancing nuclear power as a resource capable of making major contributions in meeting the nation's energy supply, environmental, and energy security needs.

The TYSP provides a long-term vision that clearly links R\&D mission goals and infrastructure requirements (single and multi-program) to INL core capabilities; establishes the 10-year, end-state vision for the three primary INL campuses; and identifies and prioritizes capability gaps, as well as proposes efficient and economic approaches to closing those gaps. The TYSP identifies the core capabilities that are operational, in progress, or planned at INL. The TYSP links DOE-NE's R\&D mission goals to INL core capabilities and infrastructure, evaluates their current condition, and identifies and prioritizes infrastructure and capability gaps, as well as the most efficient and economic approaches to closing those gaps. The TYSP proposes an infrastructure that can be maintained within projected funding levels and builds on the existing infrastructure, where possible, before building new, stand-alone facilities and capabilities.

With the TYSP, INL has institutionalized a planning effort that has identified the needs for additional facilities in each of the three campuses over the next 20 years. In some instances, activities to establish these capabilities are well underway, have been approved by DOE-NE, or are proposed within the 10-year window of the TYSP. In other instances, a potential need for capabilities and facilities has been identified; however, the data are not mature enough to include in the TYSP. All proposed projects are subject to National Environmental Policy Act analysis.

This Comprehensive Land Use and Environmental Stewardship Report is being developed to meet the requirement to support the development identified in the TYSP. The Comprehensive Land Use and Environmental Stewardship Report is based on land use planning activities at INL, including development of a Comprehensive and Facility Land Use Plan in $1996^{4}$. The first Comprehensive Land Use and Environmental Stewardship Report for INL was developed in 2005, with an update in 2006. This Comprehensive Land Use and Environmental Stewardship Report represents a second update that references the new material in the most recent TYSP; therefore, there is a closer tie between these two companion documents. This Comprehensive Land Use and Environmental Stewardship Report ties to the TYSP and outlines the future of the INL Site for the 10, 30, and 100-year timeframes.

The comprehensive land use planning process identifies the current condition of existing land and facility assets and the scope of constraints across INL and in the surrounding region. Current land use conditions are included in this Comprehensive Land Use and Environmental Stewardship Report; facility assets and the scope of constraints are discussed in the TYSP. 


\subsection{Stakeholder Participation}

The comprehensive land use planning process described in DOE policy and guidance encourages stakeholder involvement to provide diverse ideas and values in all phases. This report maintains the basic land use tenets and land planning assumptions that existed in the Comprehensive and Facility Land Use Plan that underwent extensive public review and approval, as well as bringing in the new assumptions from the TYSP.

This will be used as a communication tool to support TYSP implementation. All proposed projects are subject to National Environmental Policy Act and its public involvement processes. In addition, land use plans will be available to the public, including federal, tribal, state, and local stakeholders sharing an interest in INL land use. Land use planning will remain a current and living process by using adaptive management techniques that adjust management practices and direction to changes in environmental, mission, economic, cultural, and social factors.

\subsection{Assumptions and Environmental Considerations}

When developing long-term land use scenarios, assumptions must be made to provide a basis on which future development patterns can be formulated. The intent of these assumptions is to address the inherent uncertainty that is associated with future events. Over time, these assumptions may require modification as unanticipated events occur or conditions change.

Several considerations formed the basis for the current INL land use planning assumptions. These include prior land use planning assumptions from the original Comprehensive and Facility Land Use Plan, public input from the INL Site Environmental Management Citizens Advisory Board and the Environmental Management Site-Specific Advisory Board, and incorporation of DOE and INL management team's strategic vision for INL. The following planning assumptions are based on planning assumptions developed in the original Comprehensive and Facility Land Use Plan:

- INL will achieve its vision of becoming the preeminent nuclear research, development, and demonstration laboratory, a major center for national security technology development and demonstration, and remain a multi-program national laboratory.

- The INL Site and its associated $2,303 \mathrm{~km}^{2}\left(889 \mathrm{mi}^{2}\right)$ will remain under federal government management and control through at least the year 2095.

- Portions of the INL Site will remain under federal government management and control in perpetuity.

- The DOE-EM footprint will be reduced at the INL Site as the DOE-EM cleanup mission continues to completion in the year 2035.

- New buildings will be constructed to provide state-of-the-art research capabilities that are necessary to fulfill the INL mission.

- New building construction may include structures in existing facility areas and construction of new facility areas.

- To the extent practical, new building construction will be encouraged in existing facility areas (i.e., the Research and Education Campus [REC] in Idaho Falls and the Advanced Test Reactor [ATR] Complex and the Materials and Fuels Complex [MFC] at the INL Site) to take advantage of existing infrastructure.

- Construction of new facility areas should occur in the identified core infrastructure areas.

- As INL implements its mission, research and development advancements will result in obsolescence of existing buildings. 
- As contaminated facility areas become obsolete, environmental remediation, decommissioning, and decontamination will be required.

- The environmental remediation, decommissioning, and decontamination process will be completed in accordance with the existing regulatory structure.

- The federal government will authorize and appropriate sufficient funds to provide adequate controls (i.e., institutional controls or engineered barriers) for areas that pose a significant health or safety risk to the public and workers until the risk diminishes to an acceptable level for the intended purpose.

- Regional economic development is closely related to the activities of INL. The significance of INL's influence on the region depends on the diversity and strength of the regional economy.

- Cooperative partnerships between the public and private sectors may be developed to support modernization and expansion of INL research and development facilities.

- In accordance with DOE Order 144.1, Administrative Change 1, "Department of Energy American Indian Tribal Government Interactions and Policy," DOE recognizes that a trust relationship exists between federally recognized Tribes and DOE. DOE will consult with Tribal governments to ensure that Tribal rights and concerns are considered prior to DOE taking actions, making decisions, or implementing programs that may affect the Tribes.

- No residential development will occur within INL Site boundaries, although potential development may occur in Idaho Falls.

- Grazing will be allowed to continue on the INL Site in designated areas.

- To protect human health and the environment, INL Site operations, including onsite disposal, will remain in full compliance with applicable environmental laws, regulations, and other requirements.

In addition to the assumptions listed above, the following underlying assumptions from the TYSP also were considered when contemplating the capabilities necessary to support the DOE-NE Roadmap and desired end-state in 2022:

- INL will continue to manage its infrastructure as a shared national resource and expand the user facility concept to encompass the broader capabilities of INL beyond fuels and materials.

- The number of uncleared, onsite visitors and collaborative partners will grow, increasing the need for unrestricted access to experimental capabilities and data visualization in an open campus environment as much as possible within REC (e.g., Center for Advanced Energy Studies, a proposed new National Scientific User Facility building, the Energy Systems Laboratory, and the planned Research Education Laboratory).

- Safeguards and security requirements will continue to be more restrictive, with direct impact on management of special nuclear material and access requirements for uncleared personnel.

- Unneeded special nuclear material will be dispositioned. Remaining mission-essential special nuclear material will be consolidated and stored at a central location. The special nuclear material inventory and associated safeguards and security capabilities are unique assets that will attract other R\&D organizations.

- Expeditious completion of disposition of fast reactor fuel using electrochemical processing will enable the Fuel Conditioning Facility and the Hot Fuel Examination Facility to be more fully utilized for DOE-NE R\&D.

- Multi-program synergy and capabilities stewardship is key to developing effective nuclear energy solutions. R\&D capabilities that serve multiple DOE-NE programs are developed using Idaho Facilities Management Program funding. Dedicated, program-specific capabilities are developed and maintained using program funding. 
- INL's workforce, facilities, and infrastructure will be sized, within budgetary constraints, to meet its nuclear energy, national and homeland security, and environment and energy mission and programmatic objectives.

It is assumed further that during the planning process, potential impacts to resources and uses that may be affected by implementation of a project will be considered. The planning process will typically consider existing resources/environmental characteristics (e.g., topography, bedrock geology, surface soils, water resources, biota, and cultural resources; existing uses of the land; and natural hazards) wildland fires, floodplains, and seismicity. These resources are described in Section 4 of this report. Analysis of potential impacts to these resources will occur on a site-specific basis through the National Environmental Policy Act process or other available avenues.

\section{LAND USE \\ 3.1 Location}

The INL Site is located in southeastern Idaho where it occupies approximately $2,303 \mathrm{~km}^{2}\left(889 \mathrm{mi}^{2}\right)$ (Figure 2). The property of the INL Site lies within five southeastern Idaho counties: Bingham,

Bonneville, Butte, Clark, and Jefferson (Figure 2). The INL Site measures approximately $58 \mathrm{~km}$ (36 mi) from north to south and approximately $58 \mathrm{~km}(36 \mathrm{mi})$ from east to west at its broadest point. The INL Site is $212 \mathrm{~km}$ (132 mi) southwest of Yellowstone National Park, $72 \mathrm{~km}$ (45 mi) northwest of the Fort Hall Indian Reservation, $377 \mathrm{~km}$ (234 mi) north of Salt Lake City, Utah, and $319 \mathrm{~km}$ (198 mi) east of Boise, Idaho. The eastern boundary of the INL Site is $39 \mathrm{~km}(24 \mathrm{mi})$ west of Idaho Falls, Idaho. In addition to the site, INL currently maintains a number of buildings within the City of Idaho Falls, Idaho. The functions performed at these facilities include basic research, applied engineering, and administrative services.

The land that comprises the INL Site has experienced a long and varied history that ranges from prehistoric times, when it was inhabited by nomadic groups of Native Americans, to modern times, where it is the location of a world-class nuclear research center. A detailed history of INL was compiled by Susan Stacy in Proving the Principle - A History of the Idaho National Engineering and Environmental Laboratory 1949-1999. ${ }^{5}$ Information from that compilation and the "INL Cultural Resource Management Plan" (DOE/ID-10799) is presented in the following sections.

\subsection{Historical Land Use}

\subsubsection{Land Acquisition History}

The boundary of the current INL Site was created through several land transfers. Beginning in 1943, the U.S. Department of the Navy withdrew a 61,609-hectare (152,238-acre) area from public domain. This area was commissioned as the Naval Proving Ground on August 2, 1943. In January 1949, an additional 231 hectares (571 acres) were withdrawn.

On February 18, 1949, AEC, a predecessor agency to DOE, approved the Idaho site as its new NRTS. That same year, AEC increased the size of the new NRTS and began important nuclear energy research and engineering. By 1950, jurisdiction over land within the Naval Proving Ground had been transferred from the Navy to AEC and an additional 94,161 hectares (232,678 acres) had been transferred from the public domain to AEC for use in atomic energy R\&D. Over the next 10 years, AEC made additional land acquisitions. In 1958, a withdrawal of about 48,702 hectares (120,345 acres) was made and added to the INL lands, bringing the total land withdrawn from the public domain to 204,703 hectares $(505,832$ acres) ( $89 \%$ of the current-day INL Site). In 1974, changing missions led the NRTS reserve to be renamed the Idaho National Engineering Laboratory. In 1975, the Energy Research and Development Administration replaced AEC, and in 1977, DOE replaced the Energy Research and Development Administration. 


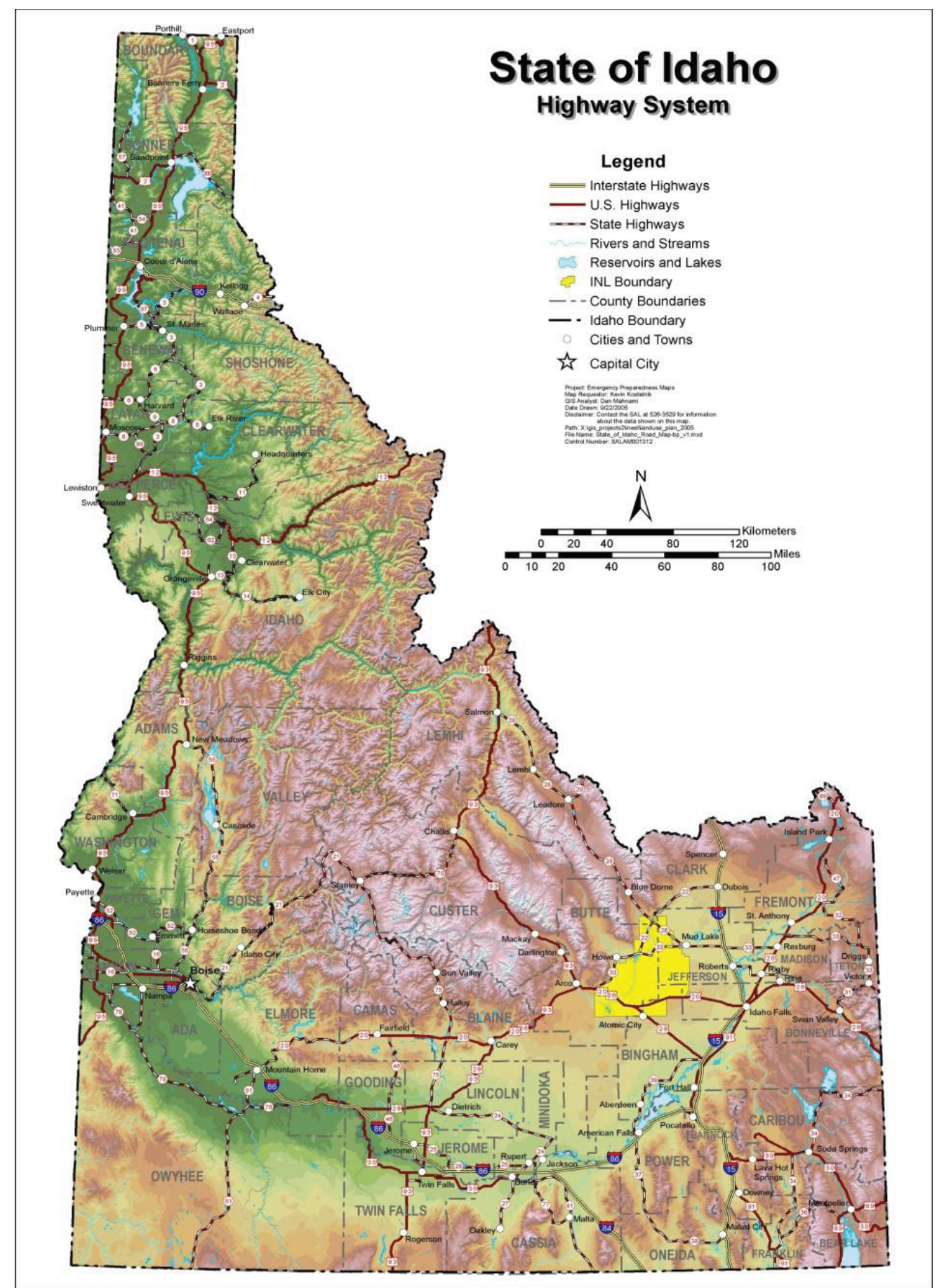

Figure 2. Idaho National Laboratory Site location in the State of Idaho.

At the INL Site, the public land owned by the federal government is administered by the U.S. Department of Interior. As such, the Bureau of Land Management (BLM) has certain administrative responsibilities, including administration of grazing permits on the land; granting utility rights-of-way across the land; extracting materials; and controlling wildfires, weeds, insects, and predators.

Congress has authorized the Department of Interior to "withdraw," or set aside, public land to meet the needs of federal agencies such as DOE. Withdrawals occur through a mechanism known as a public 
land order. The INL lands were withdrawn from the public domain through Public Land Orders No. 318, 545, 637, and 1770. The public land orders do not have specific time limitations; therefore, authority to administer these lands is expected to remain with DOE for the foreseeable future.

In addition to the land that was withdrawn from the public domain, several parcels of state-owned land (8,623 hectares [21,308 acres]) and land from private parties (15,713 hectares [43,275 acres]) were obtained to form the intact land area comprising the current boundaries of the INL Site.

The eastern boundary of the INL Site changed slightly in the late 1970s and again in the mid 1990s. The first change was made to compensate farmers who had lost productive farmland because of the catastrophic failure of the Teton Dam. The second change involved the sale of land to Jefferson County for a regional landfill. For both of these transfers, DOE relinquished that portion of their land withdrawal back to BLM, who in turn sold the land. The current-day INL land area consists of 230,321 hectares, or 569,135 acres $\left(2,303 \mathrm{~km}^{2}\right.$ [889 $\left.\left.\mathrm{mi}^{2}\right]\right)$. Figure 3 illustrates land ownership status of the INL Site.

\subsubsection{Prehistoric Uses}

This unique environment's most prominent physical feature consists of three volcanic buttes known as the Big Southern, Middle, and East Buttes. An abundance of lava rock located throughout the region provides further evidence of the area's past volcanic activity. The Big Lost River and Birch Creek, along with early spring rains that variably fill the numerous playas, provide the necessary water to sustain wildlife populations. Many animals make their homes in the sagebrush-steppe habitat, including pronghorn, deer, elk, coyotes, bobcats, rabbits, rodents, reptiles, and many birds. Prehistorically, populations of now-extinct animals, including mammoth, bison, camel, and horse, also inhabited the area.

For thousands of years, human populations consisting of nomadic hunters/gatherers moved through the area seasonally as part of their annual subsistence round, using available wildlife and plant resources. Their activities here have been well-documented and cultural evidence consisting of campsites and associated artifacts are numerous and scattered non-randomly on the landscape. ${ }^{6}$ Additional information concerning the cultural resources associated with these lands is included in Section 4.16.1.

\subsubsection{Naval Proving Grounds}

A $702-\mathrm{km}^{2}\left(271-\mathrm{mi}^{2}\right)$ area was withdrawn from public domain on August 2, 1943, and commissioned by the U.S. Department of the Navy as the Naval Proving Ground. This site was used as an artillery test range in support of World War II military activities. Sixteen-inch battleship guns, along with 3 and 5-in. guns from the Pacific Fleet, were shipped to the Naval Ordnance Plant in Pocatello, Idaho, where they were relined and re-rifled. The Navy needed an area where they could be test fired after being refurbished. INL land was used from 1943 through August 1945 for testing of these weapons. During this time, a significant amount of Navy artillery was fired across various portions of the site. This testing resulted in the deposition of large numbers of both exploded and unexploded ordnance in various regions of the site. In late 1945 and 1946, stationary explosive testing was conducted for the Army-Navy Safety Board, now called the U.S. Department of Defense Explosives Safety Board. The tests were critical in assisting with modification of the U.S. Explosive Safety Quantity-Distance Standards that were originally developed in 1928. Additional non-nuclear ordnance testing continued until AEC took over the land from the Navy in 1949.

In support of this artillery and explosives testing, a portion of the land was used for support services and residences. A rail service center was established to deliver materials and equipment to the site from Pocatello. In addition, small houses and barracks were built for the permanent officers, their families, and ordnance workers, and a red brick barrack housed the Marines who guarded the Naval Proving Ground. Workshops, storage buildings, a security building, and cafeteria also were constructed to support operations at this remote location. This center was named Scoville after Navy Commander John A. Scoville, who was the officer in charge of the test site. 


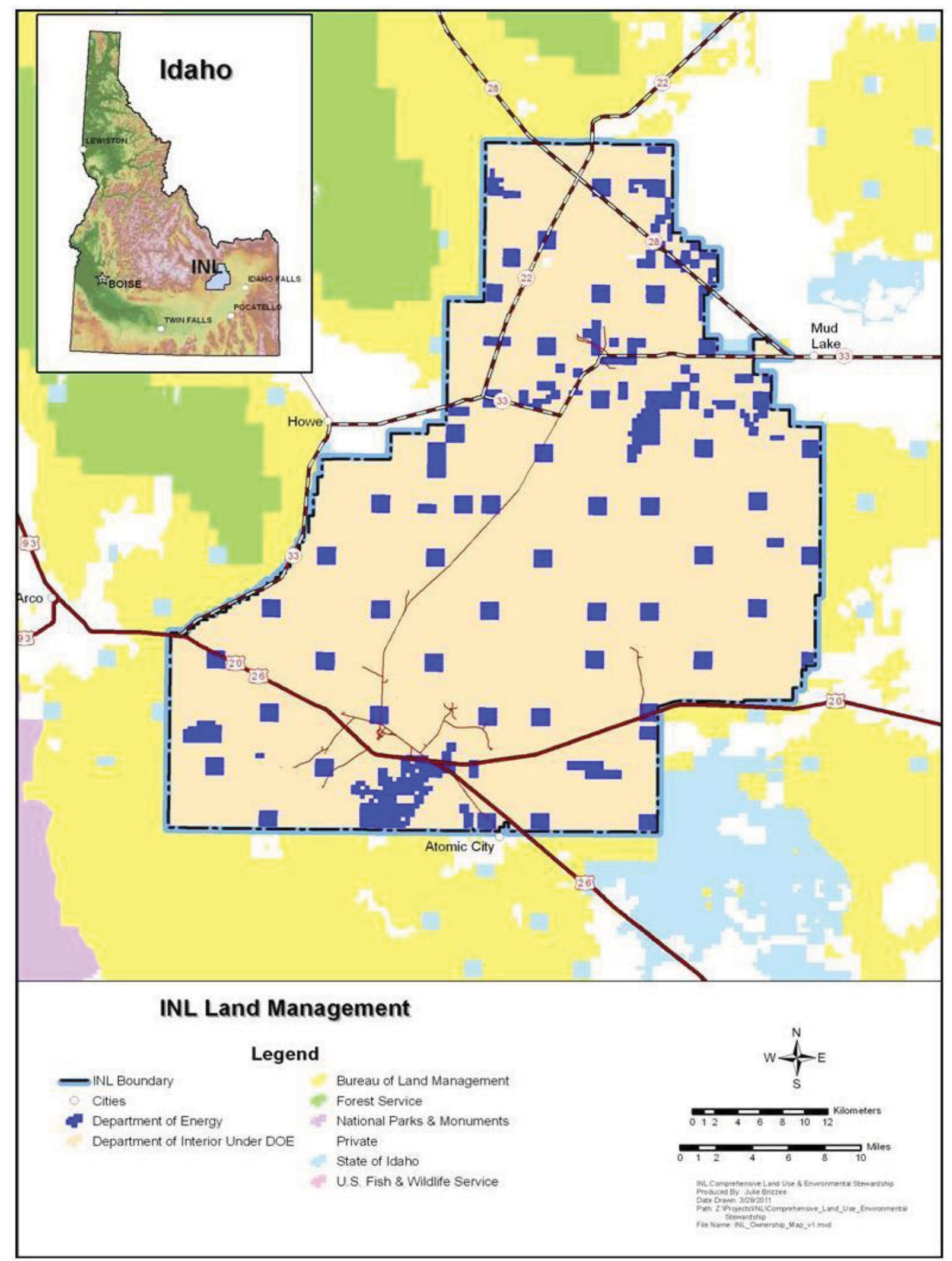

Figure 3. Idaho National Laboratory Site land ownership. 
In support of the Vietnam War, the U.S. Navy decided to reline a number of the 16-in. barrels on its battleships. To accomplish this relining, the Naval Ordnance Plant in Pocatello was reactivated to fabricate the new liners. From 1968 to 1970, the relined barrels were test fired toward the Big Southern Butte from an area south of Highway 20 and the Central Facilities Area (CFA).

\subsubsection{National Reactor Testing Station}

The NRTS was created in 1949 when the newly formed AEC selected the Naval Proving Ground site as its location to perform safety tests on a variety of nuclear reactors. The Idaho site's conditions (i.e., remote, yet well serviced via the railroad spur to the Scoville center) satisfied the needs of AEC. The site's large size allowed nuclear power test reactors to be located far enough apart to support various safety tests without adversely affecting other facilities.

Over the years, 52 different nuclear reactors were constructed at the NRTS. Additional information about these nuclear reactors is available on INL's webpage. ${ }^{7}$ In general, these reactors were used in tests to determine the viability of nuclear power and their performance and response to severe accident conditions. Because of the nature of the testing, the prevailing strategy of the time was to isolate the test reactor facilities away from other operations. An example of this strategy is evidenced at the Experimental Breeder Reactor-I (EBR-I). On December 20, 1951, EBR-I made history by producing the first usable amounts of electricity from atomic energy. Today, EBR-I is preserved as a National Historic Landmark site.

In addition to reactor viability, performance, and safety, testing at the NRTS heavily focused on other aspects of nuclear technology. Much of this work was performed at the Test Reactor Area (now the ATR Complex), the Idaho Chemical Processing Plant (now the Idaho Nuclear Technology and Engineering Center [INTEC]), and Test Area North (TAN).

\subsubsection{National Laboratory}

The NRTS became the Idaho National Engineering Laboratory in 1974, reflecting the site's multi-program national laboratory status. This designation highlighted the broad range of technical activities conducted at the site. This work included large engineering system testing and demonstration work, as well as national security and environmental restoration work. In 1975, the Idaho National Engineering Laboratory was designated as a National Environmental Research Park, recognizing the ecological diversity and research potential of the large and relatively undisturbed land area included within its boundaries.

In 1997, the site was renamed the Idaho National Engineering and Environmental Laboratory to reflect the major environmental management effort occurring at the site. Environmental restoration efforts included locating and removing ordnance left from the Naval Gunnery Range, nuclear facility decontamination and decommissioning (D\&D) from the NRTS, waste management of various hazardous and radioactive materials, spent nuclear fuel management, and environmental remediation of contaminated soils and groundwater sites.

In 1999, the U.S. Secretary of Energy designated a large portion of the Idaho National Engineering and Environmental Laboratory as a "Sagebrush-Steppe Ecosystem Reserve," recognizing the important and largely undisturbed natural resource inventories located there.

In February 2005, with the separation of the national laboratory and environmental restoration missions into two separate contracts, the Idaho National Engineering and Environmental Laboratory was renamed INL, its current designation. At that time, the research capabilities of the Idaho National Engineering and Environmental Laboratory and the Argonne National Laboratory-West were combined. The operation of INL and the environmental restoration efforts were split into two contracts to allow each mission to remain focused. Battelle Energy Alliance, LLC was selected by DOE to manage the site 
through 2015 and transform it into the preeminent nuclear energy laboratory. CH2M-WG Idaho, LLC, was selected by DOE to manage the environmental restoration operations at the site through 2012 .

\subsection{Current Operations}

Operations at INL currently take place at facilities scattered across the INL Site and in Idaho Falls (Figure 4). This section describes the primary regulatory agreements and permits that govern operations and summarizes the cleanup activities and mission-related operations taking place at INL.

\section{9,135 Acres 889 Square Miles}

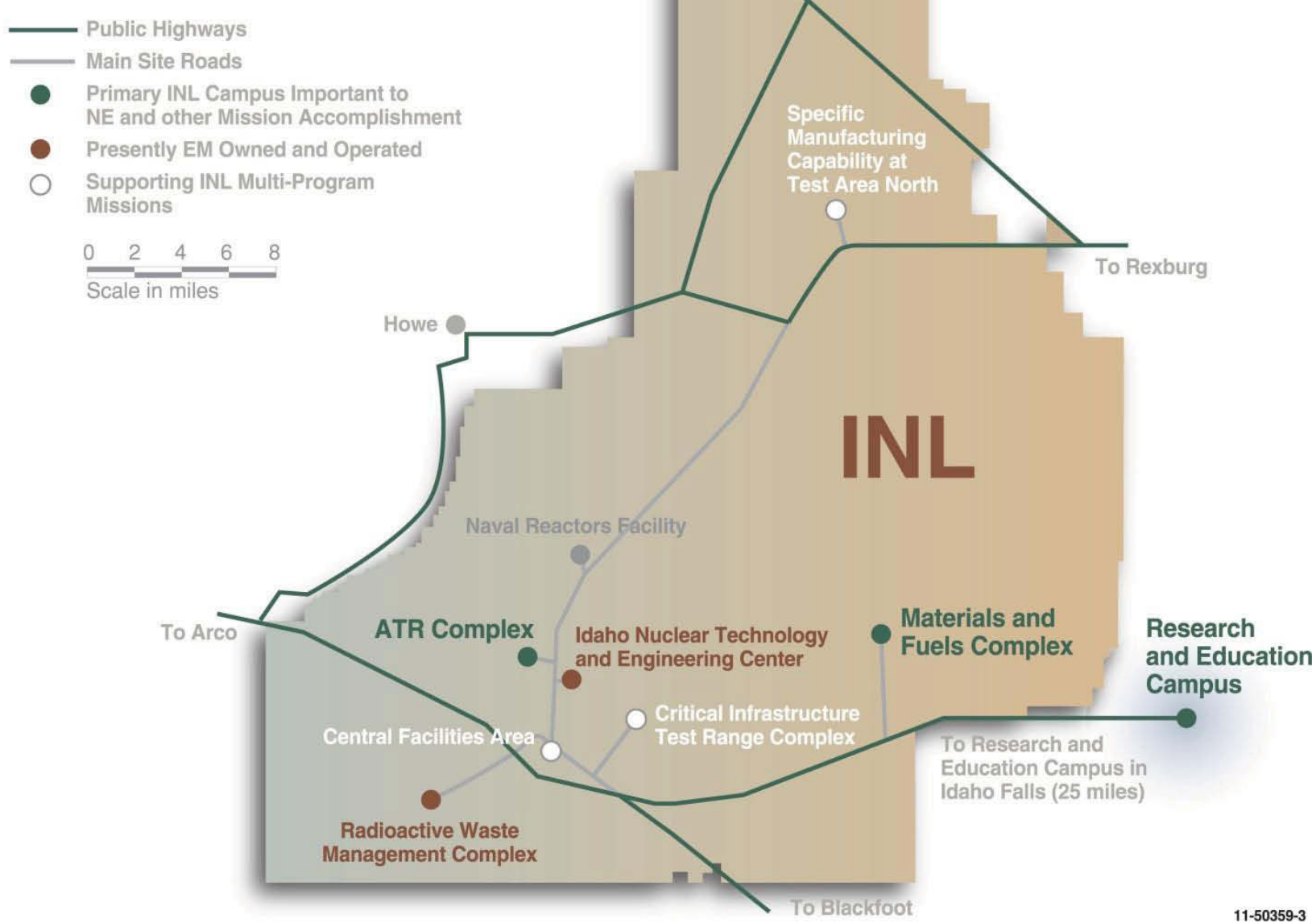

Figure 4. Idaho National Laboratory Site facilities.

\subsubsection{Regulatory Agreements and Permits}

Current INL operations include environmental remediation and ongoing research, testing, and development activities that are conducted pursuant to regulatory agreements and permits. The Comprehensive Environmental Response, Compensation, and Liability Act (CERCLA), commonly known as Superfund, was enacted by Congress on December 11, 1980, and governs environmental remediation, including remediation of federal facilities such as INL.

The INL Site was placed on the National Priorities List in November 1989. This required DOE to enter into a Federal Facility Agreement and Consent Order (FFA/CO) with the Environmental Protection Agency and the State of Idaho for effective management of the INL Site. The INL Site FFA/CO was signed December 9, 1991. Among other things, the purpose of the FFA/CO is to ensure that the environmental impacts associated with historical releases of hazardous and radioactive contaminants into 
the air, groundwater, and soils of the INL Site from projects supporting Cold War activities over the last 50 years are thoroughly investigated and that appropriate response actions are undertaken and completed as necessary to protect the public health and welfare and the environment.

A Settlement Agreement was signed on October 16, 1995, to resolve issues with the State of Idaho related to spent nuclear fuel and waste management. This Settlement Agreement detailed how DOE would specifically disposition transuranic waste, high-level waste, and spent fuel; it also identified deadlines for accomplishing these milestones. It includes a process for INL's receipt of spent nuclear fuel to prepare it for shipment outside of Idaho. It also recognizes DOE's commitment under the FFA/CO to complete all major environmental restoration activities for the INL Site by December 31, 2035.

Operating facilities at the INL Site are needed to fulfill its environmental management mission and to support the research, development, and testing mission. Operations are governed by hazardous waste and air quality permits issued by the State of Idaho. The hazardous waste permit contains requirements for each treatment, storage, and disposal unit located across the INL Site. Air quality permits are required prior to construction of major facilities; the INL Site also has received an air quality operating permit that addresses requirements for continuing operations of air emissions sources across the INL Site.

The INL Site also follows a Site Treatment Plan and Consent Order for development of capacity to treat mixed waste (i.e., hazardous and radioactive). The Site Treatment Plan and Consent Order implement the Federal Facility Compliance Act, which provides a framework for DOE sites to establish treatment capability for their mixed waste by planning, scheduling, and implementing treatment projects in accordance with enforceable milestones.

\subsubsection{Comprehensive Environmental Response, Compensation, and Liability Act Waste Area Groups}

An action plan was developed to implement the FFA/CO. For management efficiency of environmental remediation activities under the FFA/CO, the INL Site is divided into waste area groups (WAGs). WAGs 1 through 9 generally correspond to INL Site operational facilities (Figure 4), while WAG 10 corresponds to overall concerns associated with the Snake River Plain Aquifer, plus those surface and subsurface areas that are not included within the bounds of the facility-specific WAGs. A number of major environmental remediation efforts have been completed at the INL Site since signing the FFA/CO and others are ongoing. Each of the WAGs and their associated remedies and cleanup activities are briefly described in the following subsections. The current status of cleanup activities related to the WAGs can be accessed at the following website: http://ar.inel.gov. Environmental remediation work under the FFA/CO, including D\&D activities, is conducted by the Idaho Cleanup Project contractor.

3.3.2.1 Waste Area Group 1 - Test Area North. WAG 1 is the TAN area located in the northern portion of the INL Site. In general, TAN consisted of facilities originally built for handling, storing, examining, researching, and developing spent nuclear fuel. It included the Technical Support Facility; Initial Engine Test Facility; Contained Test Facility, formerly the Loss-of-Fluid Test Facility; Specific Manufacturing Capability Facility; Water Reactor Research Test Facility; and the adjacent surface and subsurface areas where operations associated with these facilities may have taken place. The U.S. Air Force and AEC Aircraft Nuclear Propulsion Program, which supported nuclear-powered aircraft research, originally built TAN between 1954 and 1961. After that research was terminated in 1961, the major program at TAN was the Loss-of-Fluid Test, which performed reactor safety testing and behavior studies. The Loss-of-Fluid Test Program ended in 1985. However, beginning in 1980, the area also was used to conduct work with material from the Three-Mile Island reactor accident (that work was completed in 2001). The Process Experimental Pilot Plant, a facility originally built to determine the capabilities of processing transuranic waste destined for the Waste Isolation Pilot Plant, also was located there.

Establishment of remedial actions was completed for WAG 1 in 2007; D\&D of the remaining facilities without an operational mission was completed in 2008. The remedy components that continue to 
be implemented for the contaminated groundwater plume beneath WAG 1 are in situ bioremediation, groundwater pump and treat, and monitored natural attenuation.

3.3.2.2 Waste Area Group 2 - Advanced Test Reactor Complex. WAG 2 is the ATR Complex, formerly the Test Reactor Area. The ATR Complex was established in the early 1950s in the southwestern portion of the INL Site and houses extensive facilities for studying the effects of radiation on materials, fuels, and equipment, including high-neutron-flux nuclear test reactors. Three major reactors have been built at the ATR Complex: (1) the Materials Test Reactor, which operated from 1952 to 1970; (2) the Engineering Test Reactor, which operated from 1957 to 1982; and (3) ATR, which began operations in 1967 and is the only major operational reactor within the ATR Complex.

Remedial actions were completed at the ATR Complex in 1999. D\&D of facilities without an operational mission continues at WAG 2, including the Engineering Test Reactor, the Materials Test Reactor, and the associated hot cells.

3.3.2.3 Waste Area Group 3 - Idaho Nuclear Technology and Engineering Center. WAG 3 is INTEC, formerly the Idaho Chemical Processing Plant, and is situated in the south-central portion of the INL Site. From 1952 until 1992, operations at INTEC were primarily related to the reprocessing of spent nuclear fuel from defense projects involving extraction of reusable uranium from spent fuels. After fuel dissolution and extraction, high-level liquid waste was stored in stainless steel underground tanks in the tank farm. The high-level liquid waste was calcined and the resultant granular solids (calcine) were stored in stainless steel bins encased in thick concrete vaults. In 1992, DOE announced that the reprocessing component of the INTEC mission would be phased out, which led to the phaseout of all related processes at INTEC. The current mission for INTEC is to receive and temporarily store spent nuclear fuel and radioactive waste for future disposition, manage waste, and perform remedial actions.

Known contaminant releases at WAG 3 are the result of spent nuclear fuel reprocessing; storage, research, and ancillary activities; and releases associated with the INTEC tank farm. Remedial actions are currently ongoing at INTEC and are expected to be completed by 2012. The remedy includes the Idaho CERCLA Disposal Facility, which accepts CERCLA waste (primarily soil and debris) from cleanup at INTEC and other WAGs. Long-term monitoring of soil and groundwater is conducted. Activities continue to eliminate sources of water releases to the perched water zone. D\&D of excess buildings also is being conducted and is planned for completion by 2012 .

3.3.2.4 Waste Area Group 4-Central Facilities Area. WAG 4 is CFA, which is situated in the south-central portion of the INL Site. CFA has been used since 1949 to house many of the support services for all operations at the INL Site. Functions housed at CFA include laboratories, security operations, fire protection, a medical facility, communication systems, warehouses, a cafeteria, vehicle and equipment pools, and the bus system. The types of CERCLA sites at WAG 4 included landfills, underground storage tanks, aboveground storage tanks, drywells, disposal ponds, soil contamination sites, and a sewage treatment plant.

Monitoring is conducted to evaluate the continued effectiveness of the remedy at WAG 4, which included installation of native soil covers over three former landfill sites. Data obtained as a result of this monitoring effort are used to evaluate the effectiveness of the landfill covers and to monitor for other potential contaminants that might be present in the groundwater from previous activities at CFA.

3.3.2.5 Waste Area Group 5 - Power Burst Facility/Auxiliary Reactor Area. WAG 5 is the Power Burst Facility/Auxiliary Reactor Area (ARA), which is located in the south-central portion of the INL Site. The Power Burst Facility area is the site of the Special Power Excursion Reactor Tests that examined nuclear reactor behavior under abnormal operating conditions and safety on light-watermoderated, enriched-fuel reactor systems from the late 1950s until 2004. It is comprised of five sub-areas. 
The Special Power Excursion Reactor Test-I reactor operated from 1955 to 1964. It was decommissioned in 1964 and demolished in 1985. The Power Burst Facility replaced it in 1970. The Special Power Excursion Reactor Test-II reactor was operated from 1960 to 1964. After the reactor was removed, the facility was converted for research purposes and was later replaced by the Waste Engineering Development Facility/Waste Reduction Operations Complex Lead Storage Facility for the temporary storage of uncontaminated lead in outdoor cargo containers. The Special Power Excursion Reactor Test-III reactor operated from 1958 to 1968. The reactor building was decontaminated in 1982, and the building was modified to contain the Waste Experimental Reduction Facility incinerator. D\&D of the incinerator was completed in 2003.

The fifth sub-area, the Control Area, was centrally located and was the Special Power Excursion Reactor Test reactor control center. It was later converted into administrative office space and included raw water storage and distribution facilities, mechanical work areas, and data acquisition resources.

The ARA also was an experimental reactor facility built in the 1950s. The ARA-I facility was built in 1957 to support the Stationary Low-Power Reactor No. 1. The Stationary Low-Power Reactor No. 1 was built at ARA-II in 1957 and operated intermittently from 1958 until it was destroyed by a nuclear accident in January 1961. At that time, ARA-I became the staging area for the emergency response to the 1961 Stationary Low-Power Reactor No. 1 reactor accident and cleanup. Construction of the ARA-III facility was completed in 1959 to house the Army Gas-Cooled Reactor Experiment research reactor. That reactor was deactivated in 1961 and the facility was modified in 1963 to support the ARA-IV reactor until the Army Reactor Program was phased out in 1965. The ARA-IV facility was built to accommodate the Mobile Low-Power Reactor I and was active from 1957 until 1964. The Nuclear Effect Reactor at ARA-IV operated from 1967 to 1970. In 1999, the D\&D of ARA was completed.

The remedy for WAG 5 is in place. Long-term monitoring is conducted for locations that are controlled for contaminated soil. D\&D activities are scheduled to be completed in 2012. This portion of the INL Site has now been designated for use as the Critical Infrastructure Test Range Complex (CITRC).

3.3.2.6 Waste Area Group 6-Experimental Breeder Reactor No. 1. WAG 6 is located in the southwestern portion of the INL Site and consists of EBR-I and the nearby Boiling Water Reactor Experiment Area, which includes the sites of five separate experimental reactors that are no longer used. Cleanup at WAG 6 included the Boiling Water Reactor Experiment-1 Burial Ground. Long-term monitoring is conducted to assess the continued effectiveness of the barrier over the site of the burial ground.

3.3.2.7 Waste Area Group 7-Radioactive Waste Management Complex. WAG 7 is the Radioactive Waste Management Complex (RWMC), which is located in the southwestern corner of the INL Site. It is divided into three separate areas according to function: the Subsurface Disposal Area, the Transuranic Storage Area, and the Administration area. Historical operations included disposal of transuranic waste and mixed waste, much of which was received from the Rocky Flats Plant nuclear weapons production facility in Colorado. Since 1970, the mission has been to dispose of low-level waste and to store, treat, and prepare stored transuranic waste for offsite shipment and disposal. Construction of the Advanced Mixed Waste Treatment Project expanded the RWMC waste management operations to include treating and preparing $63,000-\mathrm{m}^{3}$ of stored transuranic waste for shipment out of Idaho.

Remediation work at RWMC is being conducted in accordance with the 2008 Record of Decision for Operable Unit 7-13/14. Targeted waste retrieval and disposition continues under interim actions at the Accelerated Retrieval Projects. In situ grouting of 21 locations has been completed. Subsurface solvent vapor extraction continues to operate. Environmental monitoring and institutional controls have been put in place. The final remedial actions will include construction of an evapotranspiration surface barrier over the Subsurface Disposal Area when interim actions have been completed. Long-term surveillance, maintenance, monitoring, and institutional controls will preserve the integrity of the surface barrier, limit access, and enforce land use restrictions to ensure continued effectiveness of the remedy. Long-term 
management and control of RWMC will continue after construction of the surface barrier is complete and the remedy is declared operational and functional.

3.3.2.8 Waste Area Group 8-Naval Reactors Facility. WAG 8, located in the west-central sector of the INL Site, is the Naval Reactors Facility (NRF). It is comprised of the Expended Core Facility buildings, laboratories, warehouses, technical and administrative support buildings, and craft shops. NRF was established in the early 1950s to support development of naval nuclear propulsion by carrying out several functions, including receipt and examination of Navy spent nuclear fuel, examination of expended core components, development of material test specimens, examination of irradiated material test specimens, and shipment of fuel to INTEC for temporary storage. NRF, although resident on the INL Site, operates as a special-purpose facility separate from other INL Site activities. The facility operates under the direct supervision of DOE's Office of Naval Reactors.

Remedial actions were completed for WAG 8 in 2004. Engineered soil covers were constructed over three inactive landfill area, and monitoring of soil-gas and groundwater was implemented.

Removal of contaminated soil, concrete, and pipe; offsite disposal of debris; consolidation onsite of soils above remediation goals; and construction of engineered earthen covers was conducted at other contaminated locations. Institutional controls also were installed. Separate 5-year reviews are conducted for WAG 8 to assess the continuing protectiveness of the remedies.

3.3.2.9 Waste Area Group 9-Materials and Fuels Complex. WAG 9 is MFC, formerly Argonne National Laboratory-West/EBR-II research reactor. It was established in the 1950 s by AEC to support advanced nuclear reactor and nuclear fuel design and testing, including EBR-II. MFC is located in the southeastern portion of the INL Site.

All WAG 9 CERCLA remediation activities have been successfully completed and two CERCLA sites that contained radionuclides remain under institutional control per the signed record of decision. D\&D of excess facilities continues.

3.3.2.10 Waste Area Group 10 - Miscellaneous. WAG 10 includes miscellaneous surface sites throughout the INL Site that are not included in the bounds of the facility-specific WAGs. Hazards associated with WAG 10 include potential unexploded ordnance and associated explosive contaminants remaining from munitions-testing activities. This hazard area is extensive and composed of approximately 217,000 acres. WAG 10 includes the INL Site area that falls outside of the boundaries of the other WAGS, and also includes INL Site-related concerns about the Snake River Plain Aquifer that cannot be addressed on a WAG-specific basis. Consequently, WAG 10 comprises a large area, much of which is uncontaminated.

A record of decision, including decisions for Operable Unit 10-04, was signed in 2002. This record of decision included a remedy for unexploded ordnance of detection, removal, and institutional controls. Institutional controls would be maintained until the unexploded ordnance hazard is removed or reduced to acceptable levels.

A record of decision was signed for Operable Unit 10-08 in 2009 and addresses groundwater monitoring. DOE-ID will monitor INL Sitewide groundwater to confirm that there is no unacceptable threat to human health or the environment from commingled plumes or along the southern INL Site boundary. Groundwater monitoring will rely on the network of monitoring wells that currently exists and on data from other WAGs.

The CERCLA 5-year review for the INL WAGs (except WAG 8) and long-term ecological monitoring across the site are conducted as part of WAG 10 activities. Annual reviews are conducted to assess the status and conditions of institutional controls and operations and maintenance. 


\subsubsection{Long-Term Stewardship}

Long-term stewardship refers to all activities that are necessary to ensure protection of human health and the environment following completion of cleanup, disposal, or stabilization of a site or a portion of a site. Following completion of major environmental remediation efforts at the INL Site, many locations will require long-term stewardship because residual contamination will remain at levels that prohibit unrestricted access. INL will have responsibility for long-term stewardship of the INL Site once the DOE-EM cleanup mission is complete. INL, as part of its overall landlord responsibility, will manage these activities.

There are two ways sites typically become subject to long-term stewardship requirements. The first is when a site has been remediated and its remedial action objectives are completed or when its remedy is operating at steady-state (for instance, a groundwater pump and treat facility). A number of sites at INL have been remediated to the point that no hazards remain following completion of remedial operations. The second is when a site is newly identified as a No Further Action site not requiring remediation, but requiring ongoing operations and maintenance or the use of institutional controls because hazards remain, thus precluding release of these sites for unrestricted use.

Long-term stewardship includes all engineered and institutional controls designed to contain or to prevent exposures to residual contamination and waste, such as surveillance activities, record-keeping activities, inspections, groundwater monitoring, ongoing pump and treat activities, cap repair, maintenance of entombed buildings or facilities, maintenance of other barriers and containment structures, access control, and posting of signs.

Currently, the Idaho Cleanup Project contractor is responsible for implementing engineered and institutional controls at the INL Site through its INL Sitewide Institutional Controls and Operations and Maintenance Plan for CERCLA Response Actions. ${ }^{8}$ The Institutional Control Sites database is used to track the status of institutional control sites at the INL Site. Information contained in the Institutional Control Sites database includes the CERCLA site name, the location of the site, a description of the site, the contaminants of concern, the record of decision-selected remedy, controls, the objective of the controls, and the WAG under which the institutional control sites were developed. The Institutional Control Sites database is reviewed annually to verify that site requirements data are accurate. The Institutional Control Sites database is available electronically at https://cleanup.icp.doe.gov/ics. ${ }^{9}$ Figure 5 depicts the areas of the INL Site currently under institutional control requirements.

Another aspect of long-term stewardship is environmental monitoring to verify that residual hazards are managed or mitigated. Monitoring for compliance with cleanup objectives and general environmental surveillance activities are both key components of long-term stewardship for INL. DOE Order 450.1 requires that DOE implement sound stewardship practices that are protective of the air, water, land, and other natural and cultural resources that have been impacted by DOE operations. Long-term environmental monitoring is the mechanism used to verify that the contaminant concentrations are within acceptable limits and contamination is not migrating beyond acceptable boundaries. Environmental monitoring at the INL Site is performed in accordance with the requirements identified in DOE Order 450.1.

The Environmental Surveillance, Education, and Research Program under Gonzales-Stoller Surveillance LLC, conducts, manages, and coordinates ecological and environmental research, offsite environmental surveillance, and environmental education for INL. This program produces an annual site environmental report that provides consolidated information and results for effluent monitoring and environmental surveillance of air, water, soil, vegetation, biota, and agricultural products for radioactivity. The results are compared with historical data, background measurements, or applicable standards and requirements in order to verify that the INL Site does not adversely impact the environment or the health of humans or biota. 


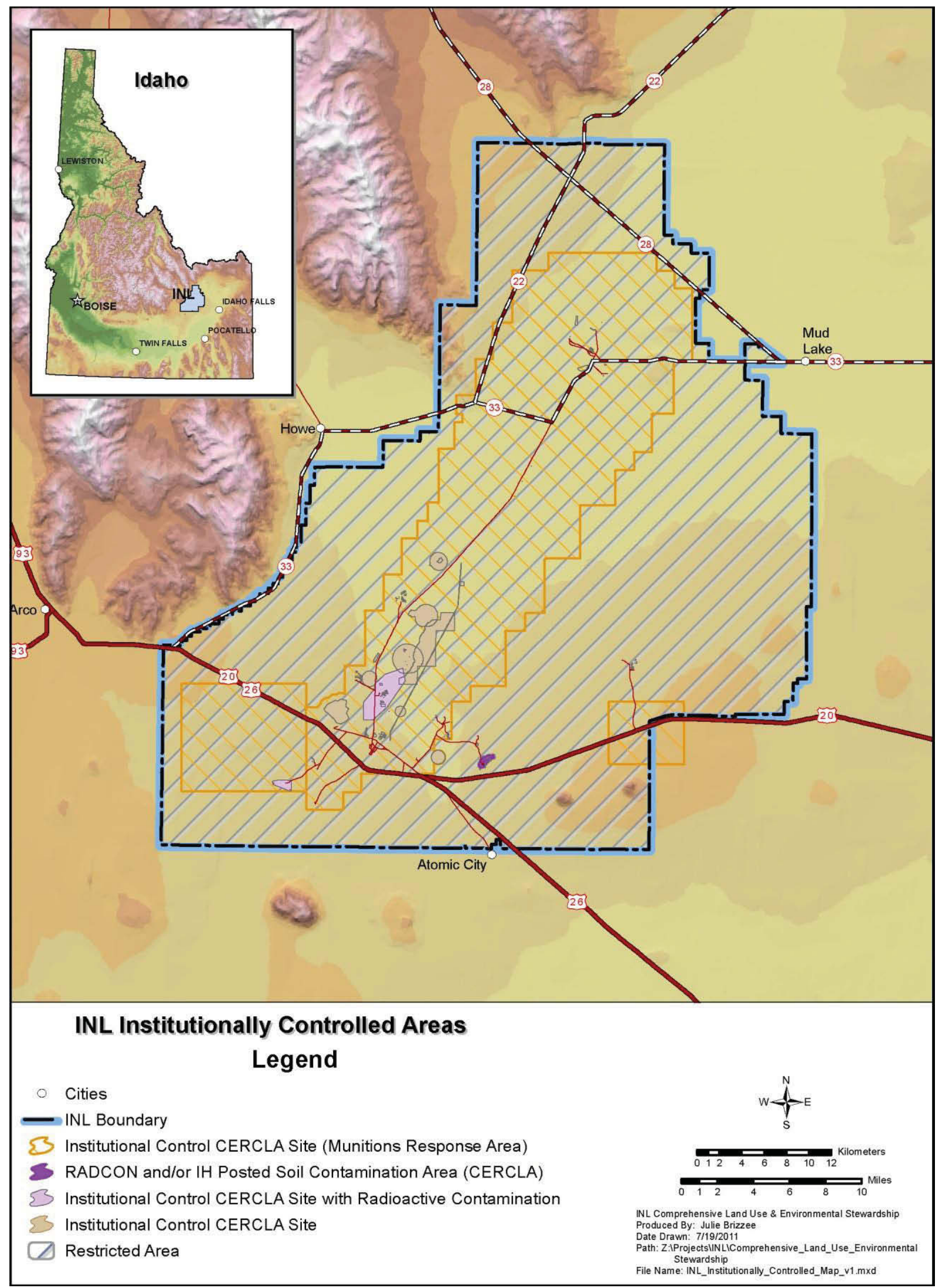

Figure 4. Idaho National Laboratory institutionally controlled areas. 
Monitoring activities associated with long-term stewardship requirements also include groundwater monitoring and ecological monitoring conducted by the Idaho Cleanup Project as part of the cleanup program. The majority of these groundwater monitoring requirements were derived from cleanup activities performed under the individual WAGs at the INL Site. Additional groundwater monitoring is performed to determine the appropriateness for consumption of water from the production (i.e., drinking water) wells. Ecological monitoring at the INL Site is conducted to verify that the objectives of INL remedial actions are maintained and to verify that the long-term sitewide ecological impact of residual contamination at INL is within acceptable limits.

\subsubsection{Non-Comprehensive Environmental Response, Compensation, and Liability Act Environmental Management Operations}

Operations are conducted at INL in support of the non-CERCLA environmental management commitments and milestones for management of waste and spent nuclear fuel. These operations are summarized in the following subsections.

3.3.4.1 Spent Nuclear Fuel Operations. The Idaho Site was the NRTS from 1949 through 1974. Fifty-two reactors were built and operated on the site. Two reactors are currently operated at the ATR Complex and MFC. Over 285 metric tons heavy metal of spent nuclear fuel (SNF) from these reactors; from other Department of Defense, DOE, and foreign and domestic university research reactors; and from commercial reactors are managed by the INL Site at INTEC, ATR Complex, MFC, NRF, and in a Nuclear Regulatory Commission-licensed facility near Ft. St. Vrain, Colorado. The Idaho Settlement Agreement requires that all SNF be in dry storage by 2023 and be removed from the state of Idaho by 2035. DOE-EM has completed transfer of all their assigned SNF to dry storage in six storage configurations located at INTEC and the Ft. St. Vrain facility. Recently generated SNF from ATR is stored in the fuel canal next to the reactor and in the INTEC CPP-666 basin. SNF from the EBR-II reactor also is stored in the CPP-666 basin and is being transferred to MFC for treatment in an electrometallurgical system. MFC also maintains a library of SNF.

The DOE baseline for disposal of SNF was packaging, transport to, and placement in the geologic repository. The Idaho Site planned to construct the Idaho Spent Fuel Facility at INTEC to package and load into transport casks all Idaho-managed SNF. In January 2010, the Blue Ribbon Commission on America's Nuclear Future was established by the Secretary of Energy to conduct a comprehensive review of policies for managing SNF and high-level nuclear waste and to recommend a new plan. The commission released draft reports in May 2011.

3.3.4.2 Sodium-Bearing Waste Treatment. Approximately 900,000 gallons of radioactive liquid waste remain in storage in underground tanks at INTEC as a result of spent fuel processing operations that ceased in 1992. Treatment of this waste is required as part of the Idaho Settlement Agreement. Emptying the tanks is required under a consent order because the tanks do not meet current requirements for secondary containment under hazardous waste laws. The Integrated Waste Treatment Unit has been constructed to treat the sodium-bearing waste. This permitted hazardous waste unit is scheduled to begin operation in December 2011. The Integrated Waste Treatment Unit involves a steam-reforming technology, placement of the treated material into waste canisters, and interim storage of the estimated 650 to 700 remote-handled canisters in concrete vaults to await shipment out of the state.

The Integrated Waste Treatment Unit will be operated to meet a milestone in the Settlement Agreement to complete treatment of sodium-bearing waste by December 2012. A decision on whether the canisters will be managed as transuranic waste and disposed of at the Waste Isolation Pilot Plant or be managed as high-level waste will be made for final disposition of the waste.

3.3.4.3 Calcine Treatment. Except for the sodium-bearing liquid waste remaining in tanks at INTEC, the liquid waste from SNF processing operations at INTEC had been processed to a solid granular form called calcine and stored in bin sets. The calcine (about $4,400 \mathrm{~m}^{3}$ ) is the subject of commitments in the Settlement Agreement and the Site Treatment Plan to prepare it for final disposition. 
In accordance with a Settlement Agreement milestone, DOE has selected the treatment technology of hot-isostatic press to convert the calcine to a glass-ceramic waste form. DOE has initiated the process of designing and permitting the facility. Under the Settlement Agreement, a hazardous waste permit application is due to be submitted for the facility in December 2012. The final milestone for calcine is to have it ready for transport outside of Idaho by 2035. This treated waste will be managed as high-level waste requiring disposal in a geologic repository.

3.3.4.4 Advanced Mixed Waste Treatment Project. The Advanced Mixed Waste Treatment Project mission is to retrieve, treat, package, and transport offsite for disposal approximately $65,000 \mathrm{~m}^{3}$ of transuranic waste in storage at RWMC (WAG 7). The project is being conducted to meet milestones under the Settlement Agreement to remove all transuranic waste from the state by a target date of December 31, 2015, and no later than December 31, 2018. More than 44,000 $\mathrm{m}^{3}$ of waste had been shipped out of the state by the end of June 2011. The Advanced Mixed Waste Treatment Project also receives offsite contact-handled transuranic waste for final packaging and transport to the Waste Isolation Pilot Plant. This waste is received and managed under the terms of the Site Treatment Plan with the State of Idaho, which includes a limit on time the waste can remain in Idaho (i.e., 6 months prior to and 6 months after treatment).

\subsubsection{Department of Energy Office of Nuclear Energy Onsite Operations}

Operations are conducted at INL in support of the DOE-NE commitments and milestones for onsite operations. These operations are summarized in the following subsections.

3.3.5.1 Idaho National Laboratory Facility Development. Based on the 2005 designation of INL as the national lead laboratory for nuclear energy research, development, and demonstration, INL is in the process of modernizing and optimizing its facility use to create an environment that fosters academic, industrial, government, and international collaborations. It is currently envisioned that INL will be composed of three modern campuses located on the INL Site and in the City of Idaho Falls. These campuses will support three primary activities: (1) nuclear energy research, development, and demonstration; (2) national and homeland security system and technology development and testing; and (3) science and technology research. These campuses include the REC located in Idaho Falls, the ATR Complex, and MFC (Figure ). Though located in separate areas, these campuses are connected by capability and function. Currently, an existing road is being improved to ease transport of materials and waste between MFC and other INL Site facilities. More information about each of these campuses is included in the following subsections.

3.3.5.2 Research and Education Campus. Since 2005, INL's in-town capabilities have been consolidated into REC (Figure 5), which serves as the "front door" to INL and comprises diverse laboratories that support research in nuclear energy, national and homeland security, and energy and environment. REC research often supports research underway in higher-hazard or larger-scale facilities at the other campuses and at U.S. universities and other national laboratories.

REC is home to a range of research capabilities and facilities and INL administrative functions. The Engineering Research Office Building is one of the main office buildings for INL staff. This facility will be augmented by a new Radiological Environmental Science Laboratory that will contain both laboratory and office space for DOE scientists and engineers.

The INL Research Center $\left(26,013 \mathrm{~m}^{2}\right.$ or $\left.280,000 \mathrm{ft}^{2}\right)$, located within REC, is a collection of laboratories that support advanced research and applied engineering in robotics, biology, chemistry, metallurgy, modeling and computational science, physics, and high-temperature electrolysis production of hydrogen for nuclear and nonnuclear applications. Its large footprint, including high-bay areas for small-scale pilot plant research, enables INL to advance bench scale and basic research concepts into viable, integrated systems for DOE-NE and other customers. 
The Center for Advanced Energy Studies $\left(5,110 \mathrm{~m}^{2}\right.$ or 55,000 $\mathrm{ft}^{2}$ ) (a \$17-million research facility partially funded by the State of Idaho) opened in 2008. A collaborative partnership between Idaho's public universities and INL, the Center for Advanced Energy Studies (along with the National Scientific User Facility Program) serves as a gateway to the research capabilities of INL and a center for cross-organizational and peer-to-peer technical collaboration.

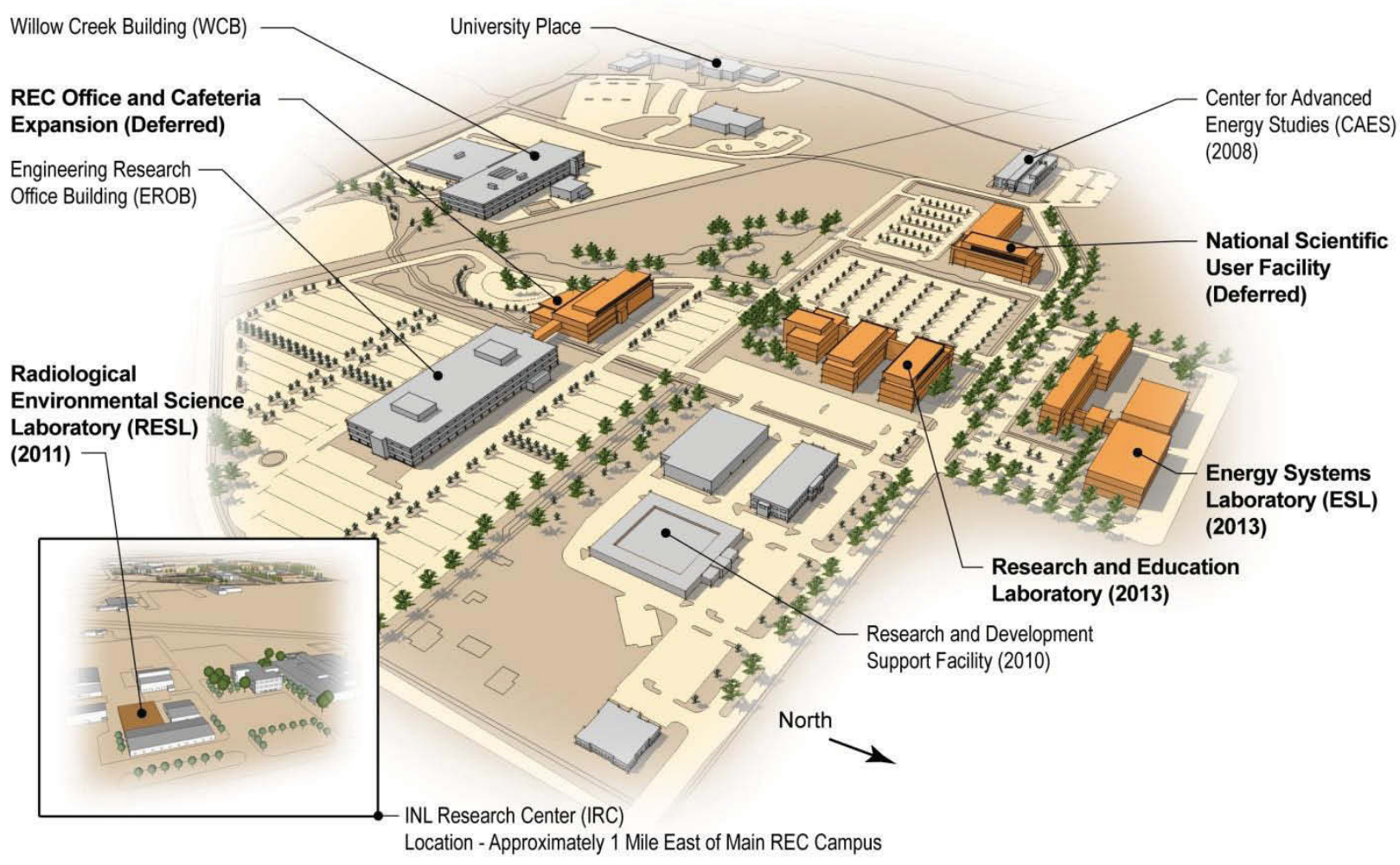

Figure 5. Research and Education Campus.

REC also includes three facilities dedicated to INL's National and Homeland Security mission that were acquired since 2005 to house researchers and program capabilities requiring secure locations for machining, fabricating, assembly, and systems operations. A new R\&D support facility has been acquired under lease arrangement to support the National and Homeland Security mission. National and Homeland Security missions take place at REC, CFA, CITRC, and MFC, while clean energy systems development and integration and synergistic environment research is concentrated at REC.

Other key facilities underway or planned at REC under lease arrangements to support the diverse INL energy and environment missions include an Energy Systems Laboratory to be operational by 2012 and the Research Education Laboratory to be operational by 2013 (which also will support separations research). The Energy Systems Laboratory will provide laboratories and high-bay areas for developing and demonstrating bioenergy feedstock processing, energy storage, a hybrid-energy systems testing program, and a visualization cave. These facilities are being co-located to better integrate the research components of synergistic, comprehensive energy systems. A new building is proposed for the National Scientific User Facility to be built by mid-decade.

INL also is considering expanding its hybrid energy system demonstration capabilities in the 2015 timeframe to emphasize nuclear power as part of a to-be-established larger-scale component testing and integration capability. Equipment requirements associated with each stage of facility/technology development currently are being developed. 
3.3.5.3 Advanced Test Reactor Complex. Located $72 \mathrm{~km}$ (45 miles) west of Idaho Falls, ATR is the world's most advanced materials test reactor (Figure 6). A low-temperature, pressurized water, cooled reactor for steady-state irradiation, ATR is fully subscribed meeting the needs of DOE-NE, Naval Reactors, the National Nuclear Security Administration, and many other research users. Other facilities in the ATR Complex include the associated ATR Critical Facility, a Test Train Assembly Facility, and a supporting radioanalytical laboratory that began operation in $2010{ }^{1}$

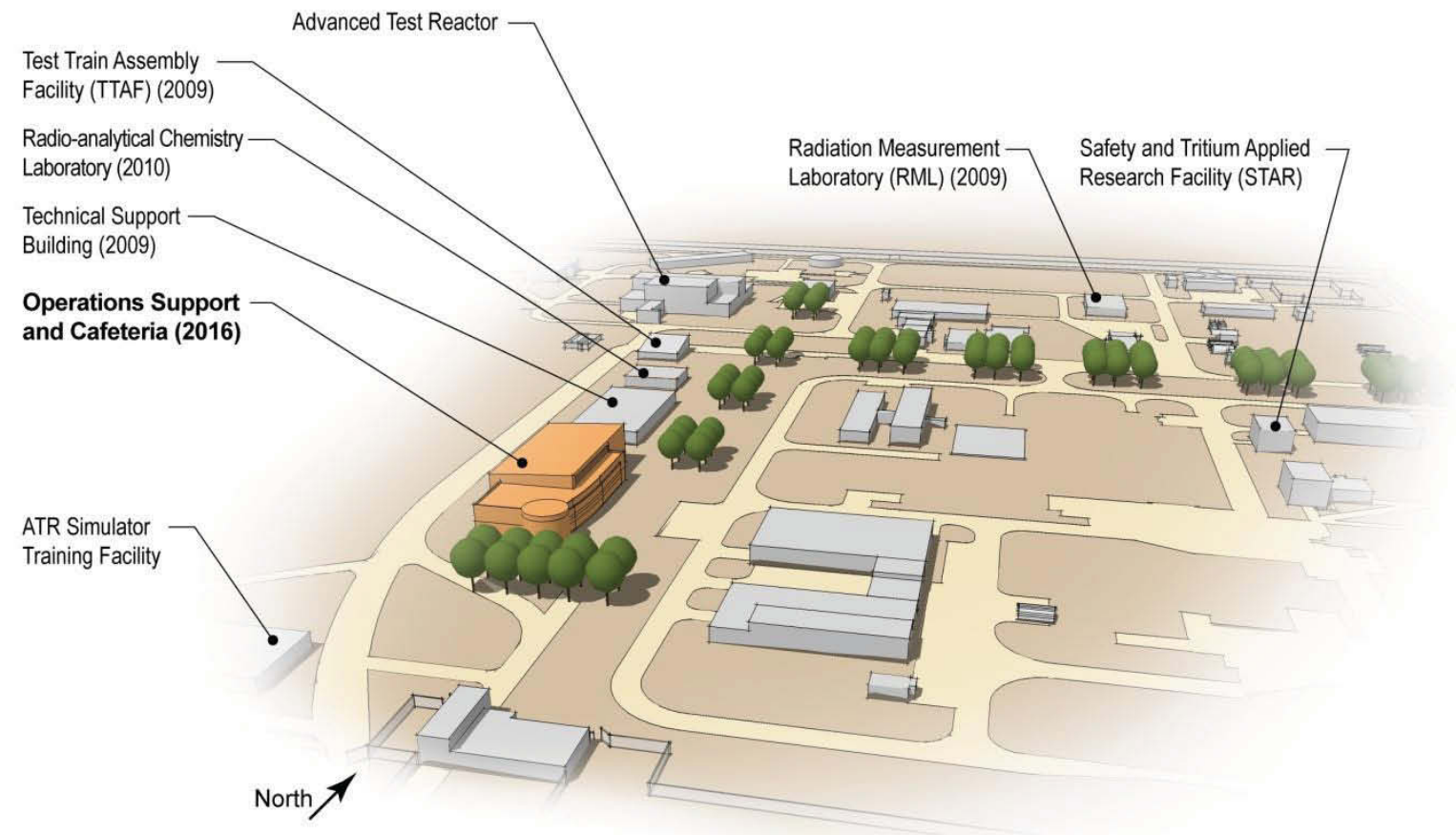

Figure 6. Advanced Test Reactor Complex.

The ATR Complex historically has supported fuel development for the Navy's nuclear propulsion program. Over the last decade, its use has expanded into other mission areas that include particle fuel development for the high-temperature gas reactor, minor actinide-bearing fuel development, and low-enriched fuel for the National Nuclear Security Administration's Reduced Enrichment for Research and Test Reactor Program, which is part of the Global Threat Reduction Initiative. In addition, ATR is one of two test reactors designated by a DOE record of decision as suitable for future production of $\mathrm{Pu}-238$. The recent D\&D of the Materials Test Reactor helped facilitate transformation of the ATR Complex. With the reactor shutdown and ancillary facilities removed, INL completed a new Technical Support Building $\left(1,524 \mathrm{~m}^{2}\right.$ or 16,400 $\left.\mathrm{ft}^{2}\right)$ in 2009 that provides essential office space for ATR Complex engineers and operators. Also in 2009, INL completed a Test Train Assembly Facility $\left(417 \mathrm{~m}^{2}\right.$ or 4,483 $\mathrm{ft}^{2}$ ) containing high precision equipment for experiment test train assembly and the Radiation Measurement Laboratory $\left(644 \mathrm{~m}^{2}\right.$ or $\left.6,929 \mathrm{ft}^{2}\right)$. A new radiochemistry laboratory $\left(427 \mathrm{~m}^{2}\right.$ or $\left.4,600 \mathrm{ft}^{2}\right)$ that is necessary to support ATR began operation in fiscal year 2010. A second support facility is proposed for 2016.

3.3.5.4 Materials and Fuels Complex. MFC, located $45 \mathrm{~km}$ (28 mi) west of Idaho Falls and formerly known as Argonne National Laboratory-West, is the center of fuel fabrication, transient testing, and post-irradiation testing at INL (Figure 7). MFC is home to the Transient Reactor Experiment and Test Facility (currently inactive but in cold standby), the Neutron Radiography Reactor TRIGA reactor used for neutron radiography, and hot cell facilities (such as the Hot Fuel Examination Facility, Fuel Conditioning Facility, and Fuels and Applied Science Building) used for post-irradiation examination and 
advanced separations and waste form research. MFC also houses analytical laboratories and an Electron Microscopy Laboratory for isotopic and chemical analyses and nanometer-scale analysis of material samples from MFC research facilities and co-located fuel fabrication glovebox lines (e.g., Fuel Manufacturing Facility and Fuels and Applied Science Building). MFC operates a facility for final assembly and testing of radioisotope power systems. ${ }^{1}$

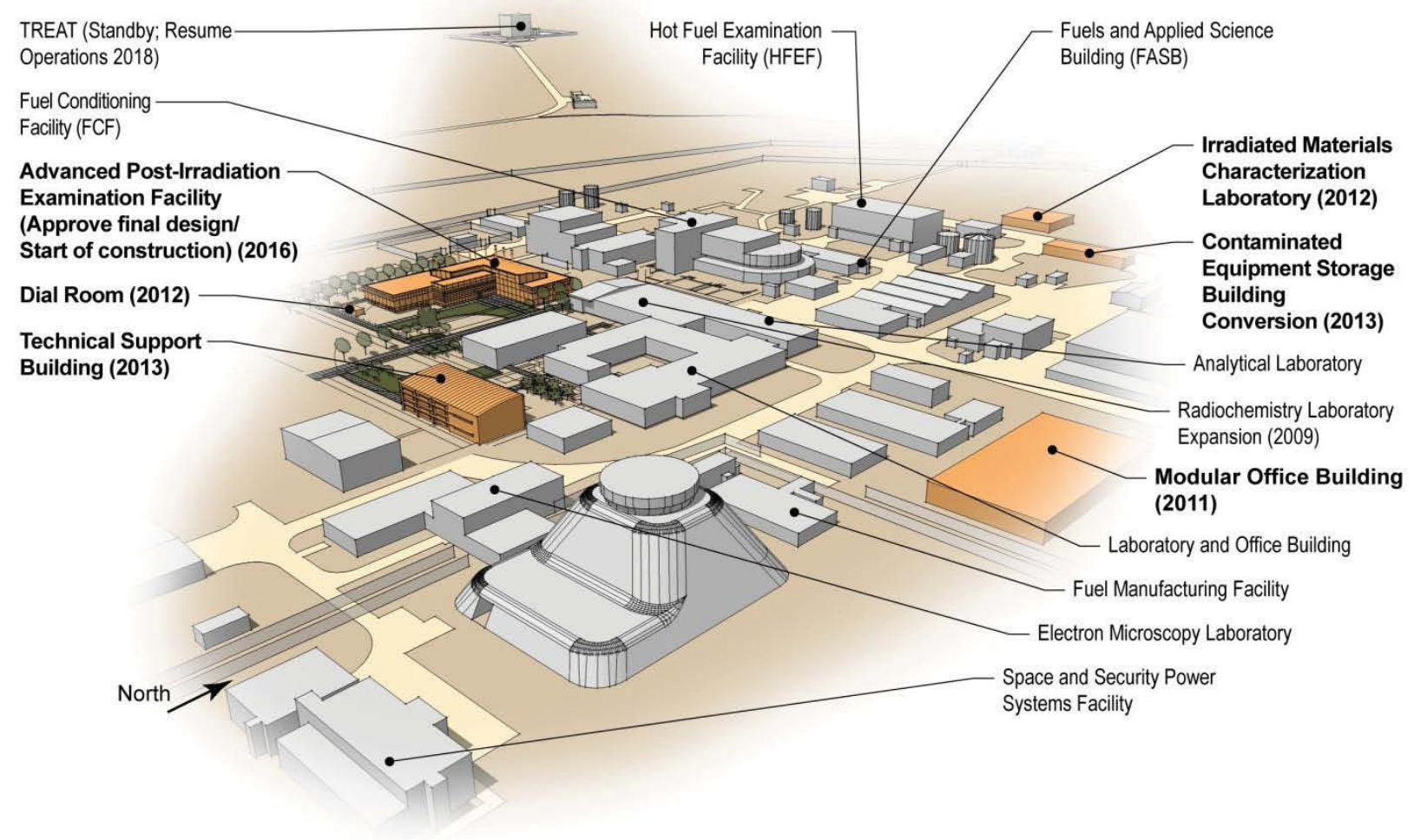

Figure 7. Materials and Fuels Complex.

Recently INL completed construction of a new Radiochemistry Laboratory $\left(763 \mathrm{~m}^{2}\right.$ or 8,200 $\left.\mathrm{ft}^{2}\right)$ at MFC and modifications are underway to convert an existing facility to provide additional radiological space for fuel development. MFC plans include construction of an Irradiated Materials Characterization Laboratory for fuels and materials characterization, a proposed new post-irradiation examination line-item facility, ceramic fuel fabrication capability, and new office buildings for INL and visiting researchers.

Efforts are underway to provide modular office space as interim space for employees while new office buildings are constructed over the next 5 to 10 years. A Technical Support Building is proposed for construction and operation, followed by future office space. New office space will provide the facility with the functionality needed to respond to the evolving needs of DOE-NE missions.

Key MFC facilities include the following:

- Fuel Conditioning Facility and Hot Fuel Examination Facility (two large hot cell facilities)

- Analytical (Chemistry) Laboratory

- Electron Microscopy Laboratory

- Fuel Manufacturing Facility (now used for experiments and nuclear materials storage)

- Engineering Development Laboratory 
- Radioactive Scrap and Waste Facility (spent nuclear fuel and radioactive waste storage facility)

- Sodium Processing Facility (a waste sodium processing facility)

- Neutron Radiography Reactor

- Transient Reactor Experiment and Test Facility

- Space and Security Power Systems Facility.

3.3.5.5 Balance of Site Capabilities. Facilities and capabilities located at other INL Site facilities also are part of INL Site operations. CFA is the main services and support area for the DOE-NE R\&D campuses at the ATR Complex and MFC. Support services provided from CFA include medical, fire suppression, transportation, security, communications, electrical power, craft support, warehousing, and instrument calibration (Figure 8). INL is developing a consolidation and revitalization plan for CFA that will include space to support National and Homeland Security missions and other site/operations.

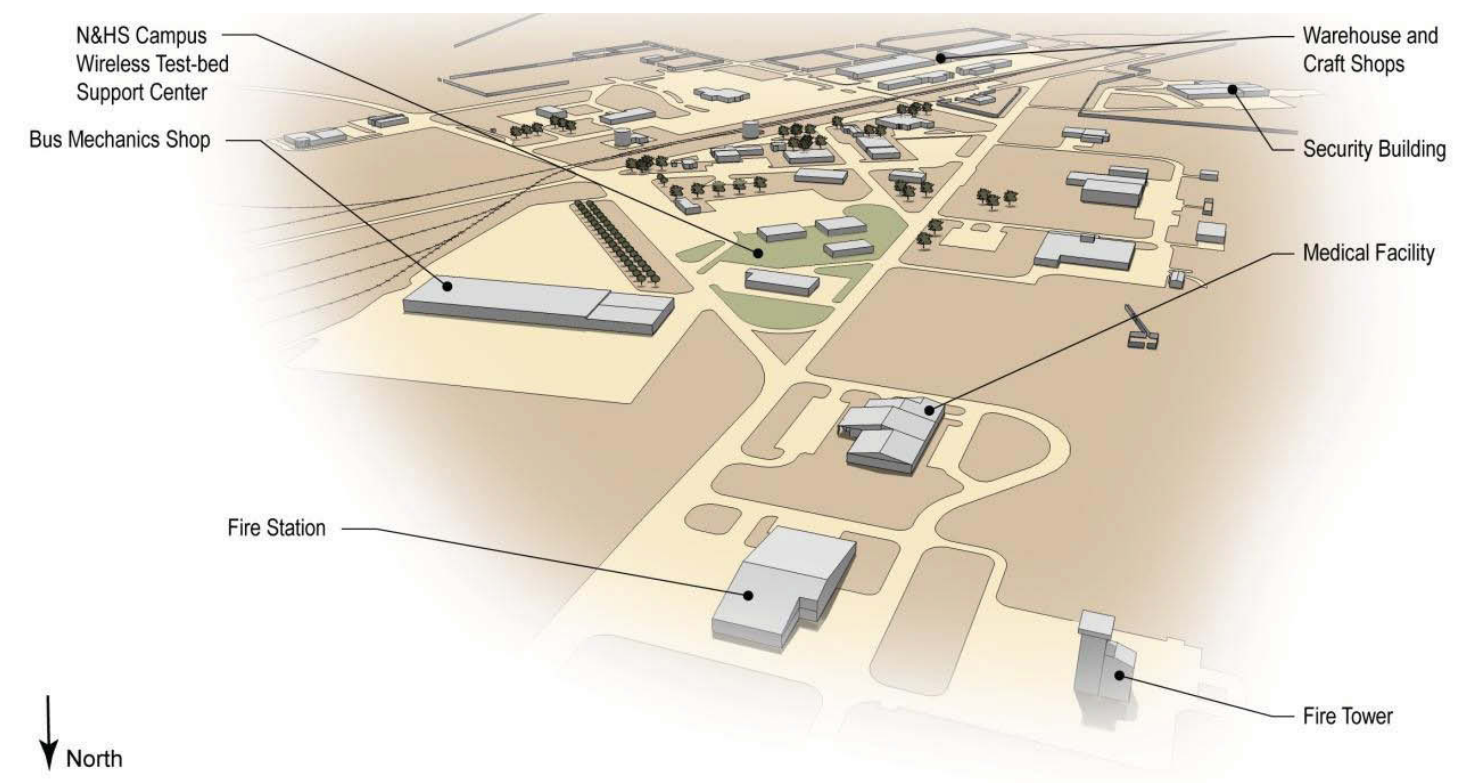

Figure 8. Central Facilities Area.

CITRC supports the National and Homeland Security missions of INL, including program and project testing (i.e., critical infrastructure resilience and nonproliferation testing and demonstration). Wireless test-bed operations, power line and grid testing, unmanned aerial vehicle testing, accelerator testing, explosive detection, and radiological counterterrorism emergency-response training occur at the CITRC area. A future electric-grid test bed is planned at the INL Site near the CFA/CITRC area, including a new reconfigurable test substation and several miles of transmission and distribution lines. An area north of TAN is being developed for a future accelerator experiment to detect illicit transport of shielded nuclear materials. An area north of MFC is being planned as a test range to test the effects of explosives on structures protective barriers and the effectiveness of potential countermeasures.

At RWMC, INL currently disposes of remote-handled low-level waste from continuing operations in concrete vaults located at the RWMC Subsurface Disposal Area. This is expected to continue until the facility is full or must be closed in preparation for final remediation of RWMC at the end of FY 2017. INL is planning to fill the need for replacement remote-handled LLW disposal capability beginning in FY 2018.

At TAN, the Specific Manufacturing Capability facility manufactures armor packages for the U.S. Army. This facility includes state-of-the-are equipment and capabilities that include light and heavy 
metal rolling, metal fabrication equipment, in-house engineering and quality department, a state-of-the-art metallurgical laboratory, and experienced manufacturing support crafts.

AT INTEC, DOE-EM owns a suite of facilities whose capabilities would provide affordable, secure, and remotely located infrastructure to meet the DOE-NE revitalization mission for the next 20 years (Figure 9). These facilities are, or will become, surplus to DOE-EM's Idaho Cleanup Project mission. INL plans to use the Unirradiated Fuel Storage Building (CPP-651) and several surrounding buildings for low-enriched uranium disposition product from electrometallurgical processing SNF.

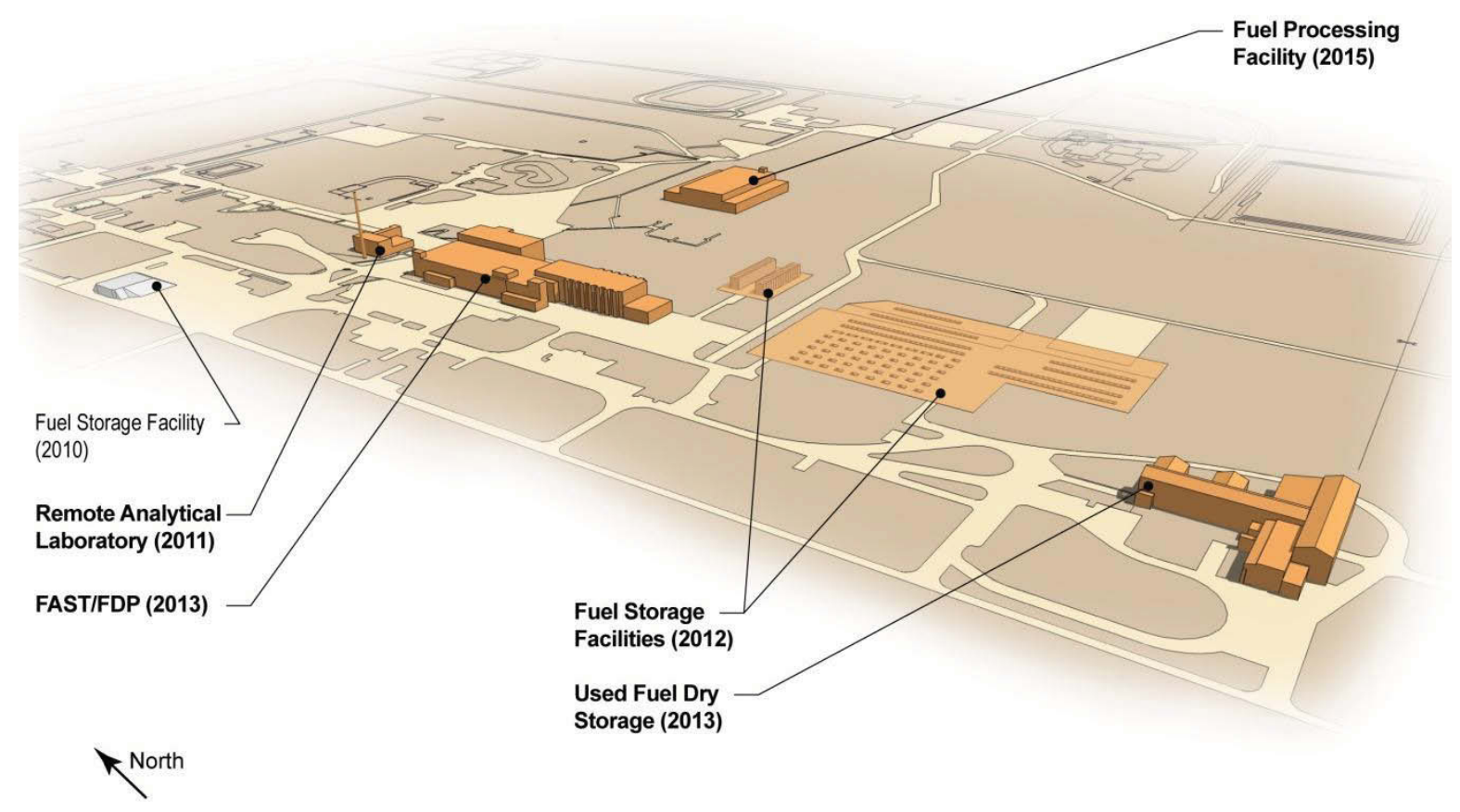

Figure 9. Idaho Nuclear Technology and Engineering Center.

Other INTEC facilities under consideration for future use include the pool at the Fluorinel Dissolution Process and Fuels Storage (CPP-666) facility, which is necessary for storage of ATR used fuel. Along with the fuel storage capabilities of the Fluorinel Dissolution Process and Fuel Storage facility, the Fuel Dissolution Process cell, which provides shielded capabilities with manipulators that could be used in the future to investigate and test advanced separations technologies, conduct extended used fuel storage studies and develop monitoring and inspection systems for used fuel storage. The CPP-603 facility and the 2707 pad would allow the capability to extract fuels, reseal casks, and store casks for extended storage studies. Additionally, INL had obtained the Remote Analytical Laboratory, which is designed for a wide range of organic, inorganic, and radioanalytical capabilities and has a modern hot cell. This laboratory offers versatility to meet near-term and continuing needs for radiochemistry work and longer-term needs for laboratory and bench-scale testing of separations technologies.

\subsection{Projected Land Use Scenarios}

As previously discussed, INL is in the process of modernizing and optimizing its facility use to create an environment that fosters academic, industrial, government, and international collaborations. Although the intent is to consolidate activities at REC, MFC, and the ATR Complex, INL will not be able to eliminate all operations at the other facility areas in the near term. Therefore, despite this footprint (building) reduction, the INL Site boundaries, and its associated $2,303 \mathrm{~km}^{2}\left(889 \mathrm{mi}^{2}\right)$, are anticipated to remain under federal government management and control for at least the next 100 years, with portions of 
the INL Site (e.g., INTEC and RWMC) remaining under federal government management and control into perpetuity.

Specific details regarding site modernization and transformation are available in the INL TYSP. The TYSP outlines the infrastructure transformation planned for INL. This includes Idaho Cleanup Project footprint reduction activities across the site and INL infrastructure modernization being planned.

The Idaho Cleanup Project is focusing on footprint reduction activities across the site, including deactivation, decontamination, and demolition at TAN and INTEC, closure of the Subsurface Disposal Area and other related cleanup at RWMC, and cleanup and facility demolition across the site. INL is planning infrastructure modernization at the main three campuses, footprint reduction at CFA, and additional facilities to support missions for customers such as the Department of Homeland Security.

There are numerous transformation issues being addressed at INL. Some of the major ones include disposal of past and future mission-related waste once the Subsurface Disposal Area is closed, treatment and disposal of the current waste inventory, and demolition of major facilities such as EBR-II. Current planning and forecasted work execution is covered in the TYSP.

\subsubsection{Idaho National Laboratory Land Use at 2022}

The INL TYSP provides a long-term vision that clearly links R\&D mission goals and infrastructure requirements (single and multi-program) to INL core capabilities; establishes the 10-year end-state vision for the three primary INL campuses; and identifies and prioritizes capability gaps, as well as proposes efficient and economic approaches to closing those gaps. The TYSP identifies the core capabilities that are operational, in progress, or planned at INL. The 10-year, end-state vision for investment in INL core capabilities and supporting infrastructure for the laboratory can be summarized as follows: ${ }^{1}$

- INL is DOE-NE's national nuclear capability. INL's world-leading core capabilities provide the majority of DOE's unique nuclear R\&D capabilities and are viewed as a shared national resource.

- INL is the DOE-NE National Scientific User Facility. INL serves as DOE-NE's user facility and provides access to the broad nuclear energy R\&D enterprise, which includes universities, industry, national laboratories, international research organizations, and other federal agencies.

- INL is a multi-program laboratory. Core capabilities are used for government and private sector customers in nuclear energy, national and homeland security, and energy and environmental research.

The INL TYSP links DOE-NE's R\&D mission goals to INL's core capabilities and infrastructure, evaluates their current condition, and identifies and prioritizes infrastructure and capability gaps, as well as the most efficient and economic approaches to closing those gaps. The TYSP proposes an infrastructure that can be maintained within projected funding levels and builds on the existing infrastructure, where possible, before building new, stand-alone facilities and capabilities.

The strategy and details outlined in the TYSP are based on a laboratory-wide analysis that links missions to existing capabilities, needed capabilities, and recommended approaches to filling the gaps. Significant progress has occurred over the last 5 years while implementing the vision. In the next decade, INL will continue to develop advanced tools and instruments, replace equipment and instrumentation, and upgrade existing systems, including, for example, the utility services at MFC.

It is anticipated that over the next 10 years new onsite development will occur, major facility D\&D will occur, and specific environmental remediation will be completed (Figure 10). INL facility infrastructure also will be reduced over the next 10 years. These footprint reductions will occur within existing operations areas. RWMC, INTEC, TAN, and other sitewide areas will continue with Resource Conservation and Recovery Act/CERCLA closure and proceed with D\&D. Included in this scenario is the transformation of existing operations areas to decommissioned and institutionally controlled areas. 


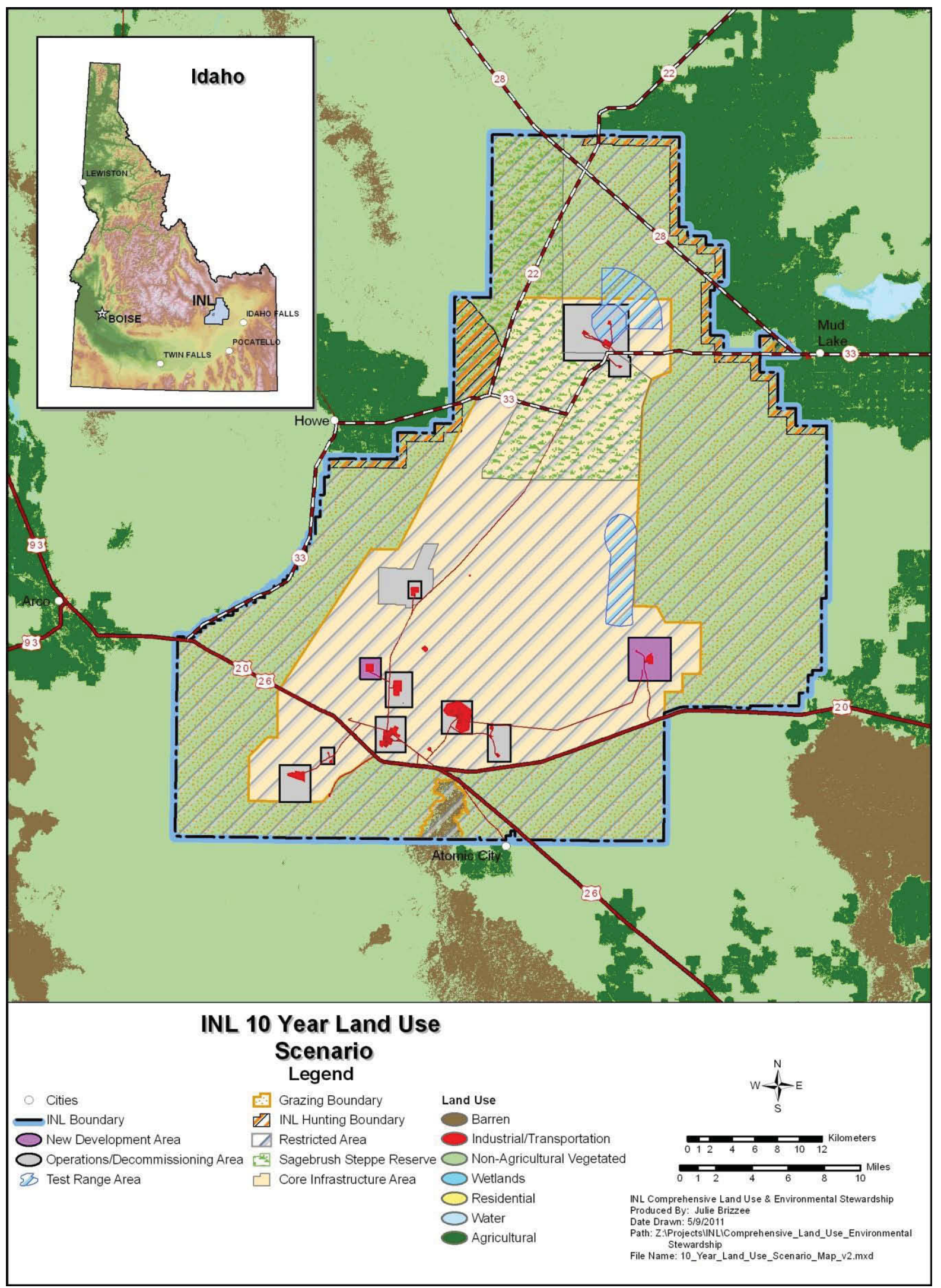

Figure 10. Idaho National Laboratory 10-year land use scenario. 
Land use in these areas will remain primarily industrial. ${ }^{6}$ INL seeks to build on existing capabilities and underlying infrastructure, as well as the economy of resource co-location over the next decade to establish the capabilities that will be needed over the next 20 years. Future development is anticipated to occur at the ATR Complex, MFC, INTEC, CFA, and REC. As INL continues to consolidate capabilities around the three main campuses, they will continue to make targeted investments that will deliver additional capacity and facilitate user access and collaboration. The strategic vision for INL builds on the current strength of each of the three main campuses. Investments to modernize each area are designed to create the form, aesthetics, and function of a campus environment that will attract and retain researchers and foster collaboration, communication, and connectivity both internally and with outside experts. A cooperative research environment in town will be facilitated by contemporary office space integrated with modeling and simulation capabilities, lower-hazard laboratory space acquired under lease arrangements, and data links between nuclear energy R\&D capabilities in town and those at MFC.

Within the WAGs, end-state land use scenarios that guide cleanup objectives support eventual unrestricted (i.e., residential) use over most of the site. The exceptions are RWMC, the tank farm at INTEC, and discrete parts of other WAGs where institutional controls are used to restrict use until cleanup objectives are achieved. Specific details regarding WAG end states are identified in WAG-specific CERCLA documents, including records of decision and proposed plans, both of which involve extensive public participation and can be accessed through INL's administrative record for cleanup (http://ar.inel.gov). The Institutional Control and Operations and Maintenance Plan ${ }^{8}$ and an Institutional Controls Sites database ${ }^{9}$ provide information on how cleanup remedies will be maintained and how institutional controls will be implemented to achieve the land use end states.

Significant D\&D has occurred in some areas of the site and consolidation at the three campuses will continue. Some new construction and new infrastructure improvement continues; however, at other sites such as CFA and INTEC, these sites will continue to function though at a significantly reduced scale. While these areas will remain, their individual boundaries will not likely expand. The only significant land use expansions anticipated at this time is addition of a transportation corridor between MFC and INTEC and the potential identification of a comprehensive utility corridor.

INL will continue to maintain two enabling capabilities: (1) utilities and supporting infrastructure, and (2) nuclear materials management. The INL 10-year vision includes proposals for several investments in significant new capabilities, which will affect the underlying utilities and supporting infrastructure. During the planning process, the supporting infrastructure (e.g., office and service buildings, roadways, and parking lots) and utilities (e.g., electrical substations, transformers, switches, communications and data links, and water and sewer systems) are being identified and included as part of the investment strategy. As part of the 10-year vision, INL is committed to taking a positive approach to maintaining utilities and infrastructure, upgrading them to a mission-ready state, and extending their useful life to support the mission needs defined in the DOE-NE Roadmap. The objectives of this approach are to effectively manage enduring assets; efficiently disposition non-enduring assets; and invest in new supporting infrastructure and utilities to make new mission capabilities possible.

\subsubsection{Idaho National Laboratory Land Use at 2041}

Land use changes within the next 30 years (Figure 11) are anticipated to be consistent with the 10 -year forecast. Specific changes beyond the 10-year horizon include completion of a number of critical environmental remediation efforts. These achievements are noted in the transition of operations/ decommissioning areas to decommissioned areas/new development areas (ATR Complex and MFC) and will continue to serve as the operational staging areas for current and new development within the core infrastructure area.

Footprint reductions will continue to occur within existing operations areas and some areas will be transformed to decommissioned and institutionally controlled areas. Some sites, such as CFA and INTEC, 
will continue to function at a significantly reduced scale. In the 30 -year land use scenario, these areas will remain, but their individual boundaries are not expected to expand.

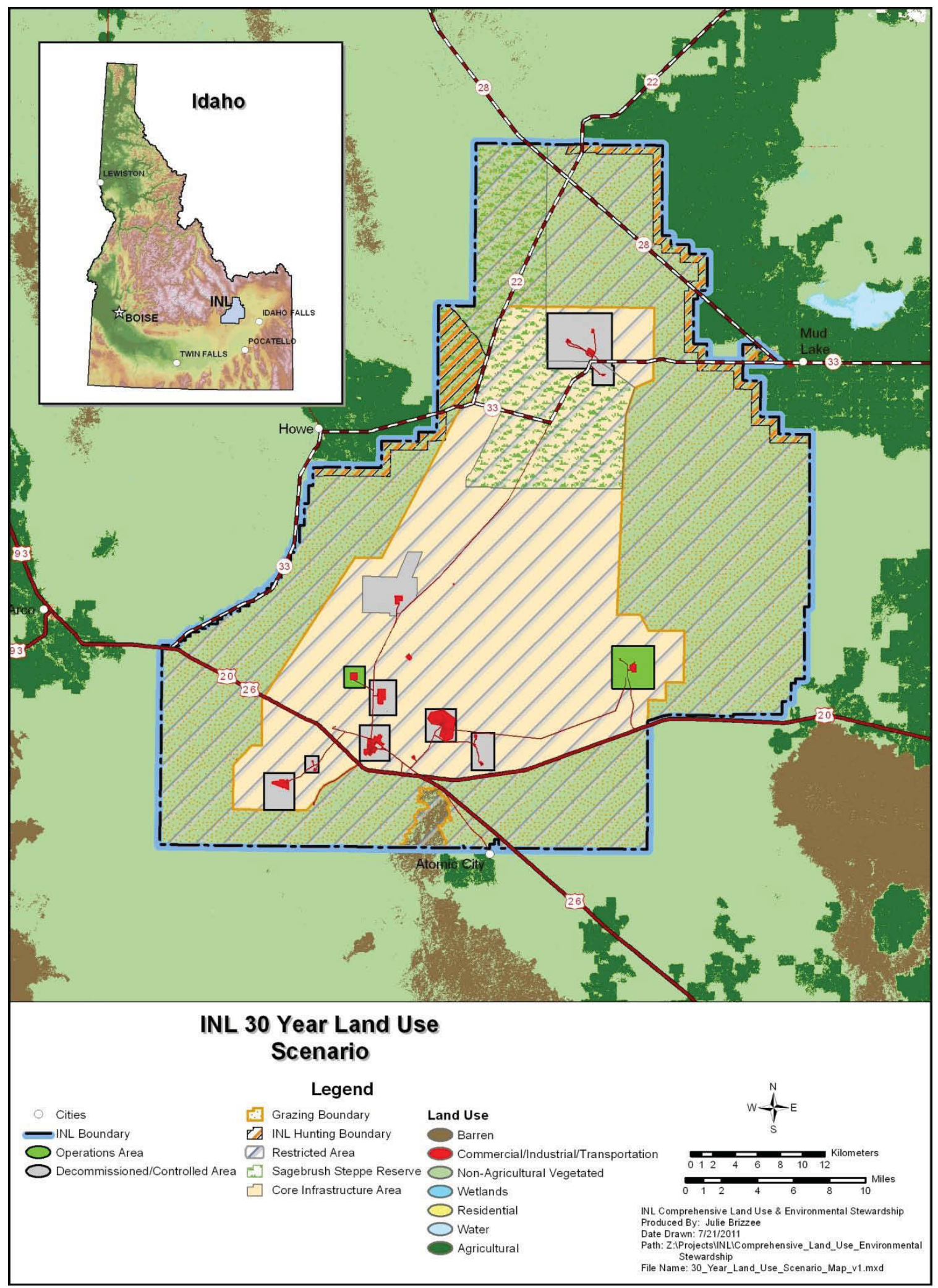

Figure 11. Idaho National Laboratory 30-year land use scenario. 


\subsubsection{Idaho National Laboratory Land Use at 2111}

INL land use for the 100-year scenario (Figure 12) remains consistent with the 30-year scenario. The decommissioned/controlled areas will be the primary focus of INL long-term stewardship functions. These activities will be coupled with sitewide administrative controls and the operational areas of the ATR Complex and MFC.

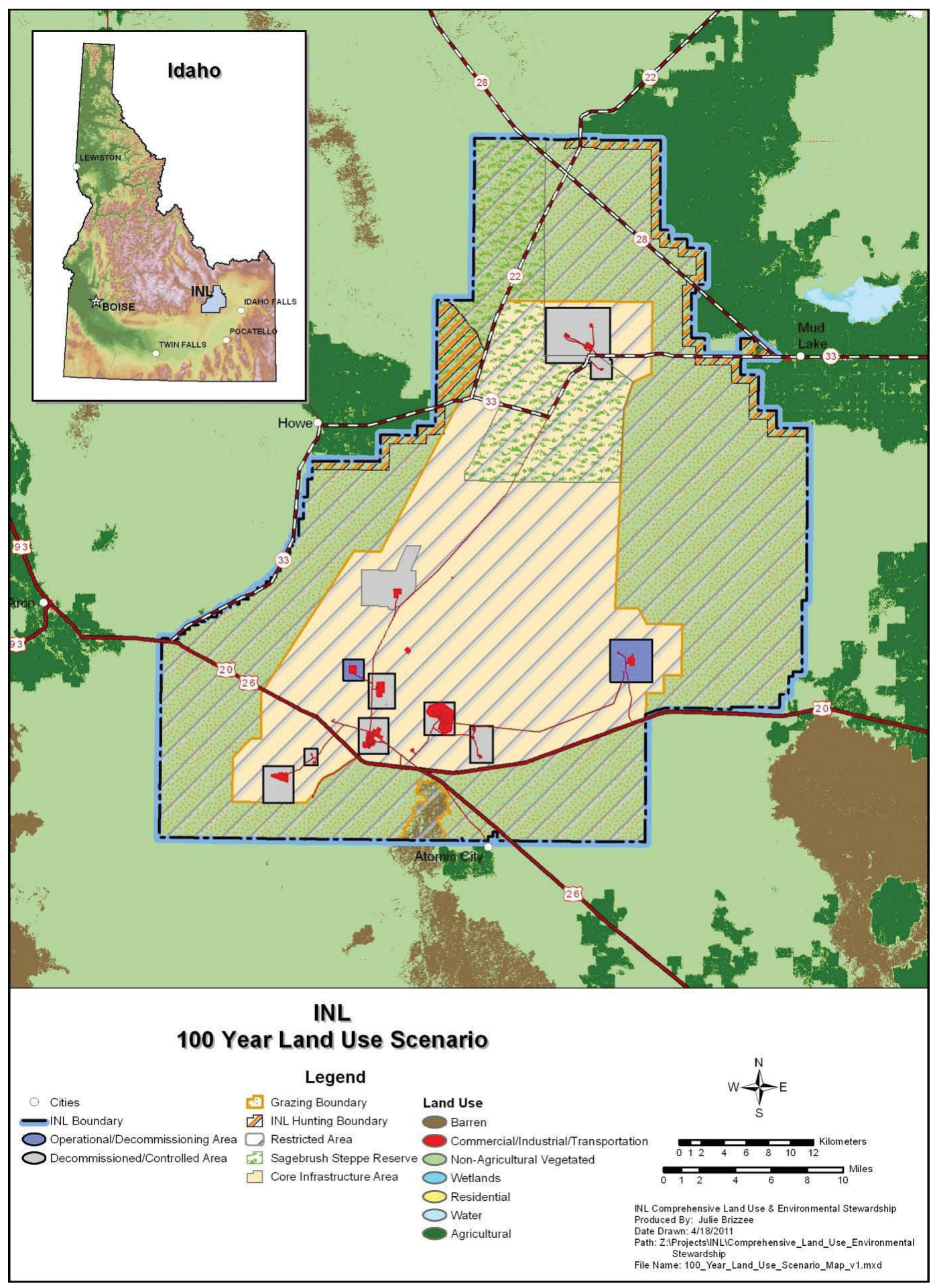

Figure 12. Idaho National Laboratory 100-year land use scenario. 


\section{ENVIRONMENTAL RESOURCE CONSIDERATIONS}

A number of environmental factors/resources at INL need to be considered during planning because of the potential for impacts to these resources from actions that may result from planning. The types of factors that are considered include the following: regional considerations such as population, land uses, and socioeconomic conditions; sitewide area infrastructure such as transportation routes, power distribution systems, communication systems, utility systems, and other land uses; resources such as soils, water resources, biota, and cultural resources; and natural hazards at the INL Site such as wildland fire, seismic hazards, and floods. Brief descriptions of existing land uses and resources present at the INL Site are presented in the following subsections and figures are provided for some of the resources. The Land Use Planning Committee will consider effects to these resources in future site-specific land use planning. More detailed resource information would be used by the Land Use Planning Committee, including current Geographic Information System layers to analyze the potential for conflicts based on existing resource conditions.

\subsection{Regional Population}

There are 16 counties within $80 \mathrm{~km}(50 \mathrm{mi})$ of the INL Site (Figure 13). Fifteen of these counties are in the State of Idaho and one is in the State of Montana. This 16-county region has a low population density. In 2010, the population for this region was $390,608 .{ }^{10}$ Nearly $48 \%$ of this population resides in the two most populous counties: Bonneville and Bannock.

The largest regional cities are Idaho Falls (located in Bonneville County), with a 2010 estimated population of 56,813 residents, and Pocatello (located in Bannock County), with a 2010 estimated population of 54,255 residents. These two cities represent approximately $28 \%$ of the regional population. The Fort Hall Indian Reservation is located south of INL. It has a 2010 estimated population of 3,201.

The entire INL Site is an administratively controlled area. In general, admittance to the INL Site and its facilities is permitted only on an "official business" basis. The Shoshone-Bannock Tribes have been granted access to an area around, and including, the Middle Butte Cave and public access is allowed in rights-of-way associated with highways, the Big Lost River rest area, and at the EBR-I visitor center. There are no human residences on INL Site property. A regional perspective of the INL Site and surrounding population centers is shown in Figure 14. Refer to Figure 15 for a more detailed view of the regional population, based on 2010 Census Blocks.

\subsection{Regional Land Use}

The region adjacent to the INL Site boundary is a combination of public and private land. Approximately $75 \%$ of the land adjacent to the INL Site is managed by the federal government and administered by BLM. This federally managed land provides wildlife habitat and is used for mineral and energy production, grazing, and recreation. Approximately $1 \%$ of the adjacent land is owned by the State of Idaho and is used for the same purposes as the federal land. The remaining $24 \%$ of the land adjacent to the INL Site is privately owned and primarily is used for grazing and crop production. In 2007, approximately 993,195 acres of cropland were in use each year within the five-county area that encompasses the INL Site. ${ }^{11}$ Population densities are generally low, with urban and suburban land uses spatially distant. The Big Southern Butte is south of the INL border and the Middle and Eastern Buttes are within the INL Site near the south border. Significant portions of these primarily federal-owned lands are used for recreational purposes, such as hunting, fishing, boating, hiking, cross-country skiing, and camping. Specific recreational and tourism sites are located near the INL Site at the Craters of the Moon National Monument, Hell's Half-Acre Wilderness Study Area, Black Canyon Wilderness Study Area, Camas National Wildlife Refuge, Market Lake State Wildlife Management Area, Mud Lake Wildlife Management Area, and the Birch Creek Camping Area. The Big Southern Butte and Hell's Half Acre are designated as National Natural Landmarks. EBR-I is a National Historic Landmark. In addition, there are 
two national forests, Challis-Salmon and Targhee-Caribou, within $50 \mathrm{mi}(80 \mathrm{~km})$ of the north and west INL Site boundaries, respectively.

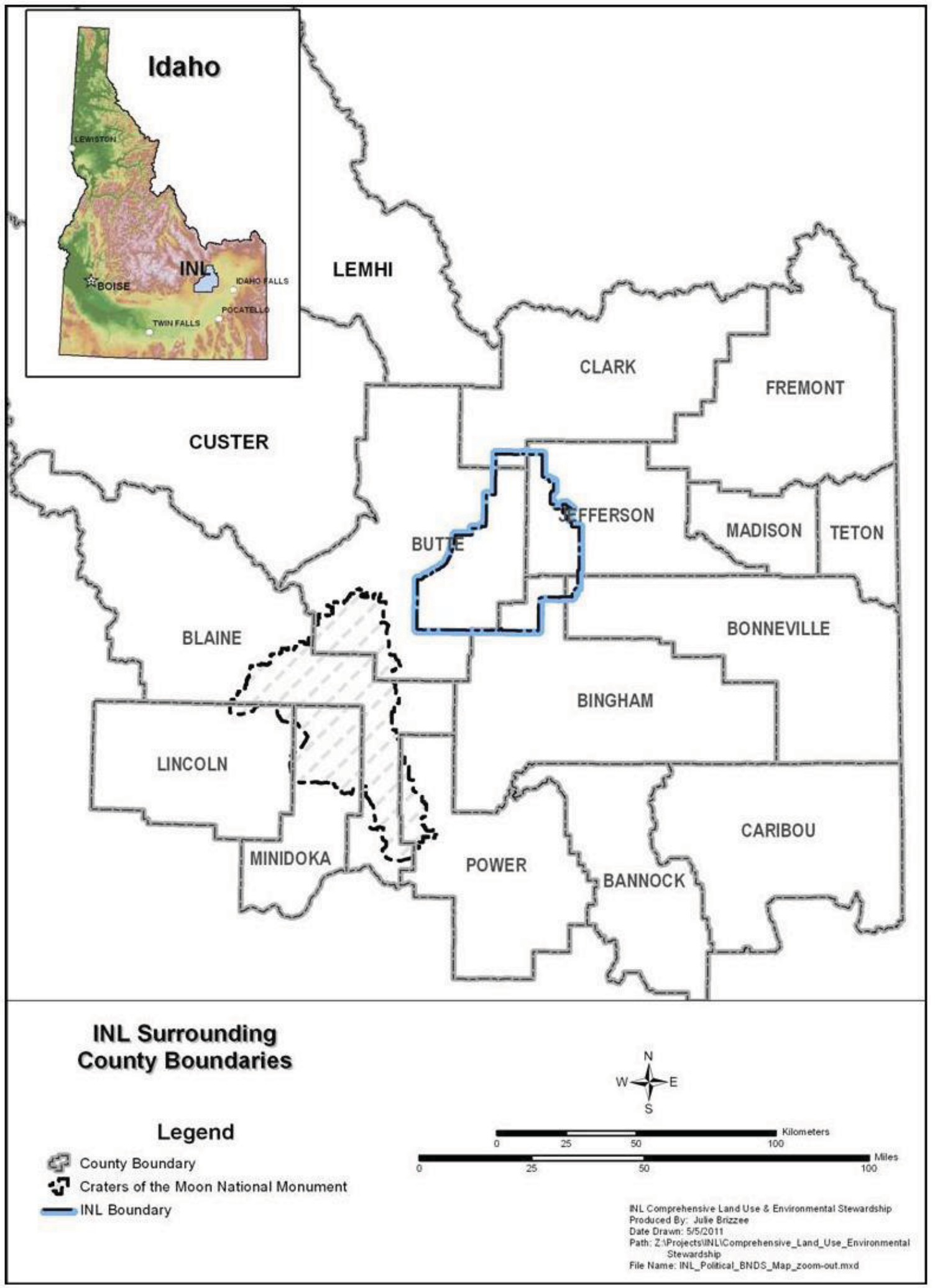

Figure 13. Idaho National Laboratory county boundaries. 


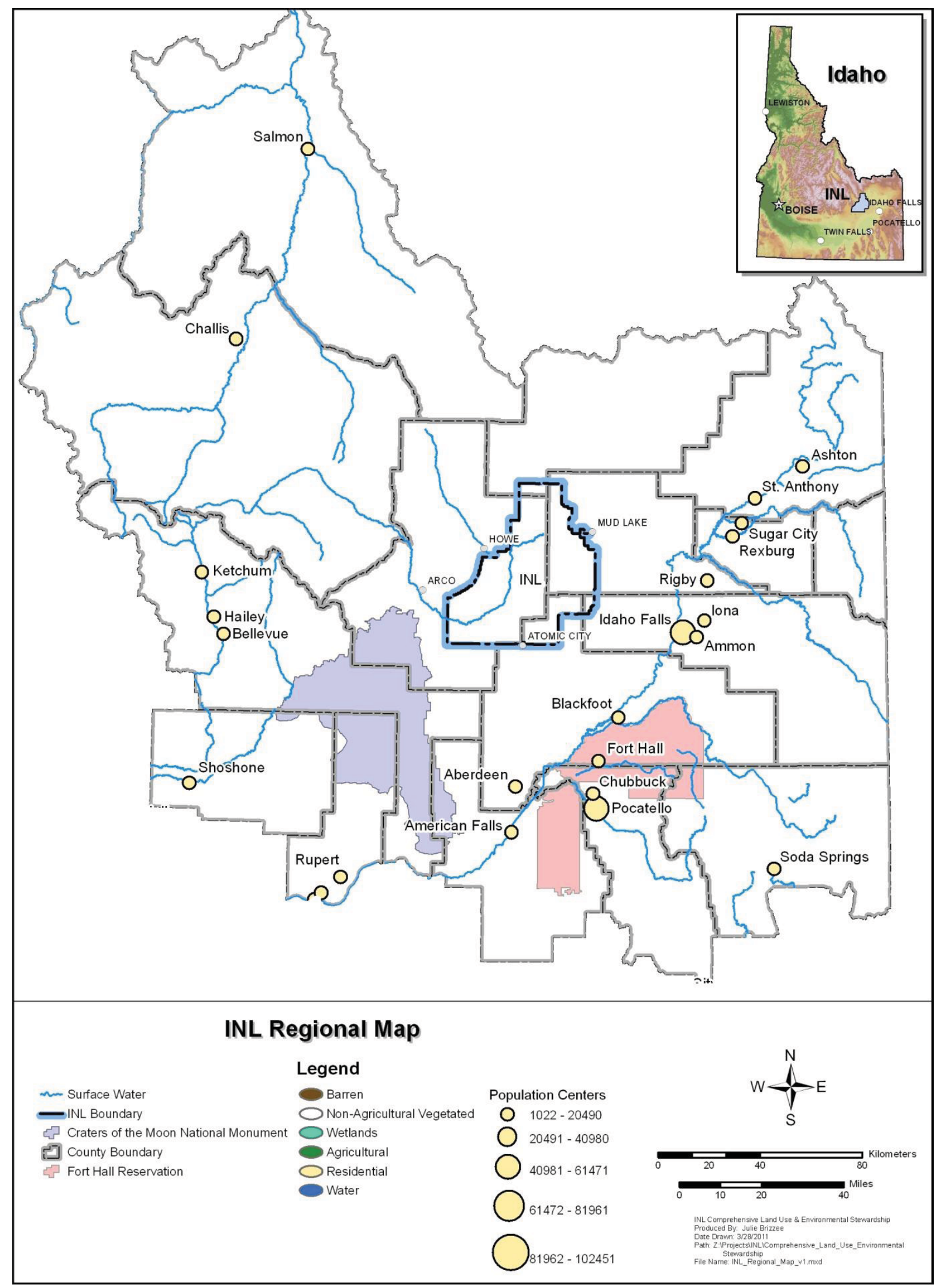

Figure 14. Idaho National Laboratory regional map. 


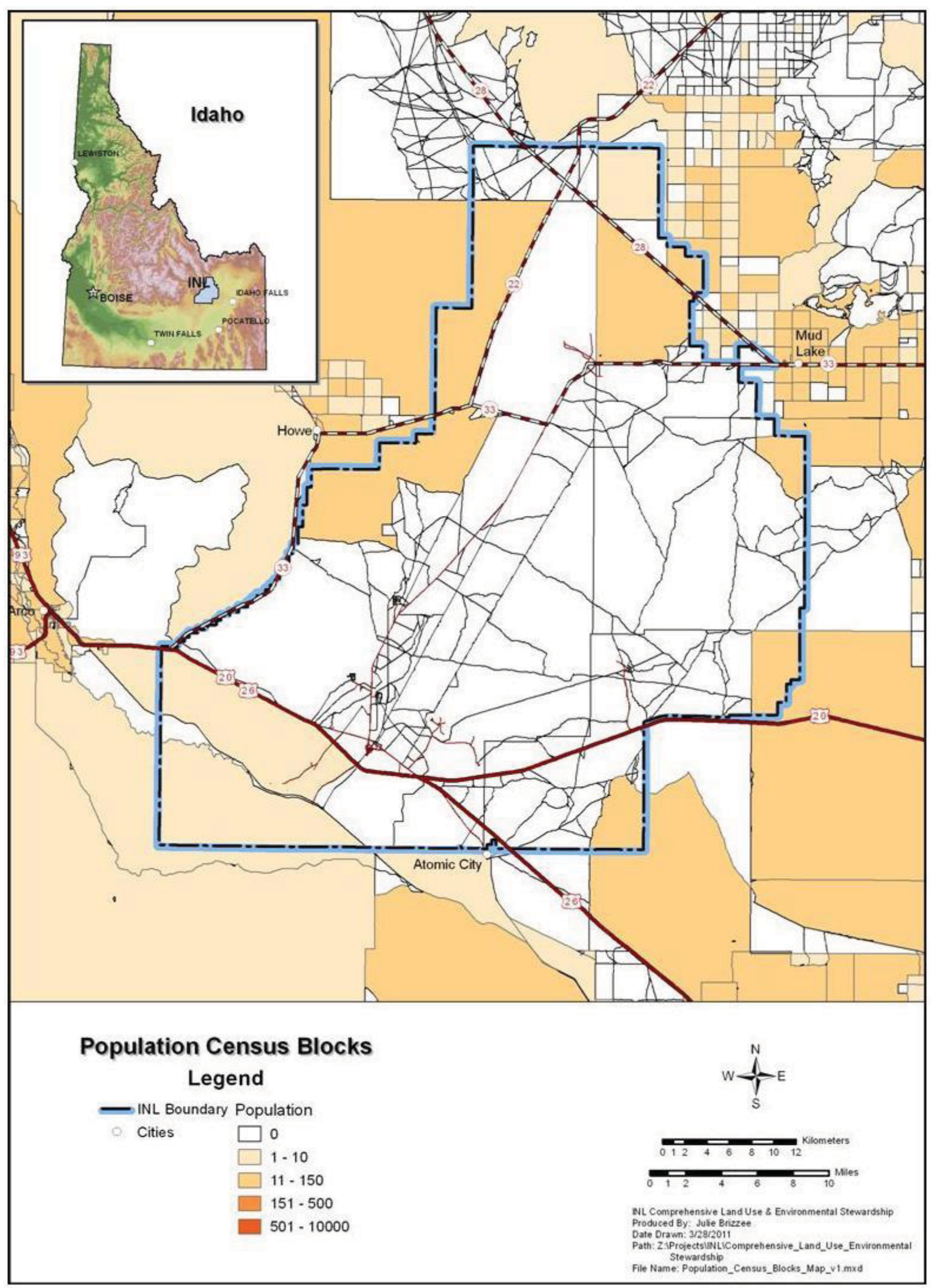

Figure 15. Population census blocks. 


\subsection{Regional Economy}

In 2006, an analysis of INL's impacts on the economy of Idaho was conducted. ${ }^{12}$ The analysis showed that with 8,452 employees and an annual budget in excess of $\$ 1.227$ billion, INL is the third largest employer in the state and the largest employer in eastern Idaho.

The combined direct and secondary economic impacts of INL operations account for 15,570 jobs annually in Idaho. Also, there are longer-term effects on the economy due to the continued presence of INL in eastern Idaho, which accounts for an additional 4,290 jobs. INL's total impact on employment in the state equals 19,860 jobs.

In addition, INL-based operations spend over $\$ 500$ million on goods and services in the state. The vast majority of these expenditures go to residents and businesses near the facility. For example, approximately $95 \%$ of wages and salaries, $85 \%$ of retirement benefits, and $80 \%$ of purchases go to residents and businesses in the 10 counties surrounding INL. These direct dollars generate secondary economic effects. Facility employees and employees of the firms that provide services and equipment to the facility spend their income on goods and services such as food, clothing, and entertainment.

The analysis performed in 2006 showed that, with 8,452 employees and an annual budget in excess of $\$ 1.227$ billion, the direct and secondary economic impacts of INL create 15,570 jobs in the state of Idaho annually, amounting to $2.7 \%$ of employment in Idaho. The direct and secondary effects on personal income amount to $\$ 1.108$ billion annually, $2.6 \%$ of total personal income in the state.

Since it has been in operation, INL has dramatically altered workforce composition and the economic landscape of the region. The economic growth generated by construction of the facility and its continued presence have acted as a magnet to other types of economic activity. These tertiary effects estimate to create 4,290 jobs and are a vital part of the long-term growth of the regional economy. These jobs, coupled with the jobs created through the direct and secondary impacts of INL, result in a total of 19,860 jobs attributable to the facility.

INL makes annual payments to the State of Idaho in the form of sales use taxes, franchise taxes, corporate income taxes, and motor fuel taxes. In addition, current and former employees pay taxes to state and local governments in the form of income taxes, sales taxes, and property taxes. The overall fiscal impact of taxes and fees paid by INL and its employees total nearly $\$ 85$ million, which represents nearly $3 \%$ of Idaho's total taxes and fees. The revenues paid to state and local governments create jobs that benefit the state and, especially, the local economies.

The presence of INL and its workforce has changed the employment composition of eastern Idaho and the state as a whole, making Idaho more economically diverse. Without INL, the eastern part of the state would be more reliant on agricultural production, agricultural inputs and transportation services. Economic fluctuations in any given sector have less impact on other parts of the economy due to the presence of a more diverse economy.

\subsection{Transportation Routes}

\subsubsection{Roadways}

Commercial transportation systems at the INL Site include road and highway systems, railroad systems, and airports. Approximately 6\% of INL Site land (approximately 13,736 hectares [34,000 acres]) is devoted to public road and utility rights-of-way crossing the Site.

U.S. Highways 20 and 26 cross the southern portion of the INL Site, while Idaho State Highways 22, 28 , and 33 cross the northern portion (Figure 16). These paved public highways measure approximately $145 \mathrm{~km}$ (90 miles). The INL Site has an additional $140 \mathrm{~km}$ (87 miles) of nonpublic paved roads within its boundaries, approximately $29 \mathrm{~km}$ (18 miles) of which are considered service roads. Finally, an additional 
$161 \mathrm{~km}$ (100 miles) of unpaved roads and trails provide additional access for emergency, security, and service vehicles. Road use is restricted to employees and visitors on official business.

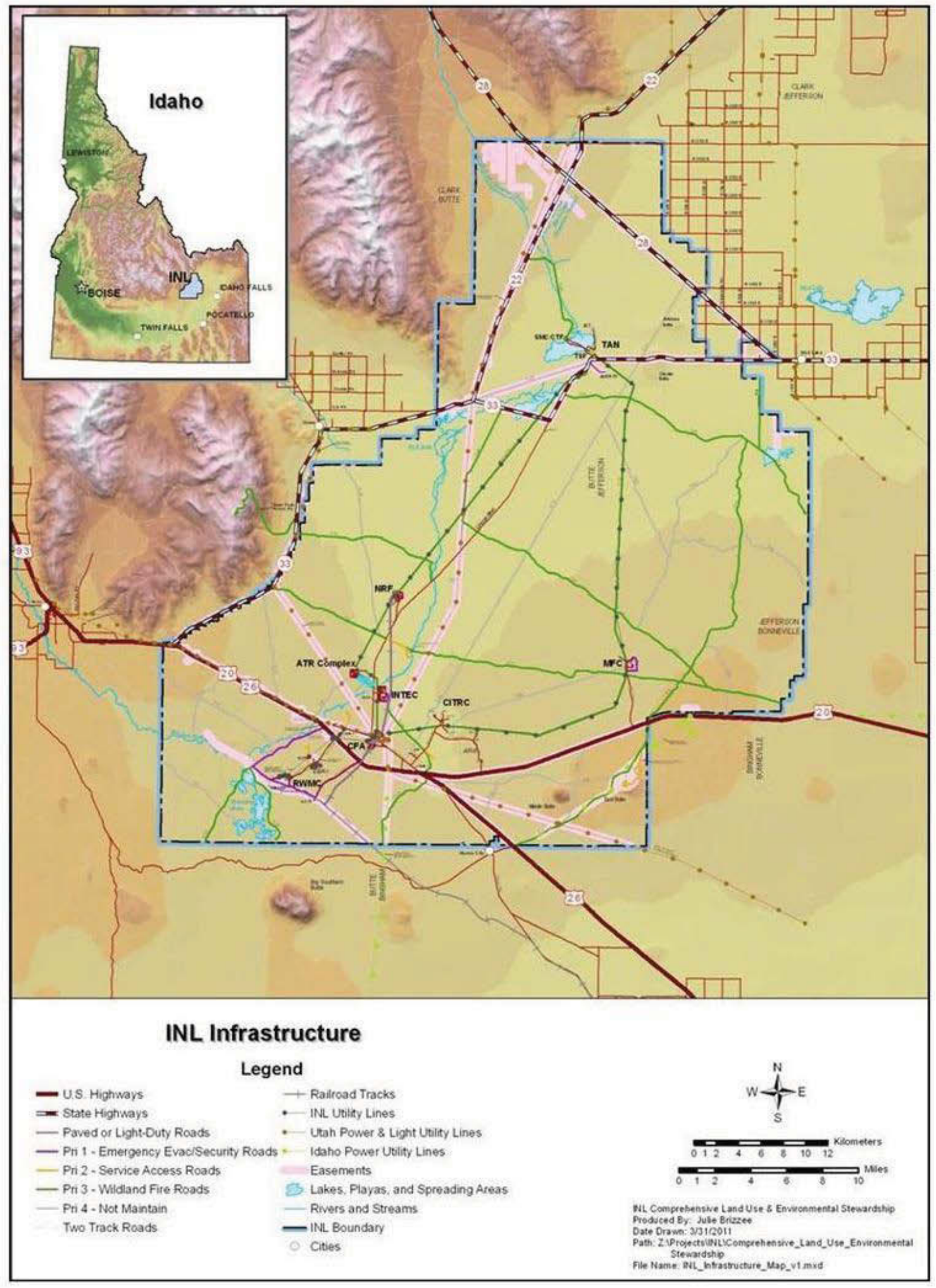

Figure 16. Idaho National Laboratory infrastructure. 
In 2010 DOE approved a project to create an additional route within INL Site boundaries to transport shipments of materials and waste expected over the next 10 years between MFC and other INL Site facilities. The 21-km (13-mile) road is being constructed; it will be a nonpublic road encompassed entirely within the INL Site. ${ }^{13}$

\subsubsection{Railways}

The INL Site has several railways that cross its property (Figure 16). The Union Pacific Railroad's Mackay Branch Line services the southern portion of the INL Site through the Scoville Spur. The $23 \mathrm{~km}$ (14 miles) of the Mackay Branch Line, which terminates in the southern part of the INL Site, services the Union Pacific Railroad's main lines, which run from Butte, Montana, on the north to Pocatello, Idaho, and Salt Lake City, Utah, on the south. Interconnections are made from these locations throughout the United States.

A DOE-owned railroad track also passes north at Scoville Siding from Mackay Branch through CFA past the east side of INTEC and terminates within NRF. A spur line runs west to connect this track through the south end of the INTEC Fuel Storage Facility and to the coal-fired plant. A portion of this line is presently out of service.

\subsubsection{Airways}

The cities of Idaho Falls and Pocatello both have airports that provide passenger and cargo service in the vicinity of the INL Site. The Federal Aviation Administration requests that pilots avoid flights below $1,800 \mathrm{~m}(6,000 \mathrm{ft})$ above mean sea level when crossing the INL Site. The INL Site operates a $305 \times 30-\mathrm{m}$ $(1,000 \times 100-\mathrm{ft})$ airfield for testing of unmanned aerial vehicles.

\subsection{Utilities}

Commercial electric power is delivered to the operating areas at the INL Site by an extensive power transmission and distribution system (Figure 16). Offsite power is fed into the INL Site power transmission system through the Scoville substation. Power to the Scoville substation (and therefore the INL Site) is provided via two transmission lines from Rocky Mountain Power's Antelope substation.

The INL Site power system includes a $138-\mathrm{kV}$ transmission loop that is $100 \mathrm{~km}$ (62 miles) long and feeds high-voltage substations. A separate $10-\mathrm{km}$ (6.2-mile), 138-kV line feeds the RWMC area with capacity in excess of $20 \mathrm{MW}$. The distribution system ranges in voltage from 13.8 to $2.4 \mathrm{kV}$ and is composed of approximately $97 \mathrm{~km}$ (60 miles) of overhead lines and several miles of underground lines. The transmission loop capacity is $50 \mathrm{MW}$. There are no gas or oil lines on the INL Site, although individual facilities may have propane or fuel storage tanks.

\subsection{Environmental Research Park}

The INL Site is a designated National Environmental Research Park. A National Environmental Research Park is an outdoor laboratory that offers opportunities for environmental studies on protected lands that serve as buffers around DOE facilities. The National Environmental Research Park system provides protected lands for research and education, particularly to demonstrate the compatibility of energy technology development and a quality environment. INL's designation as a National Environmental Research Park has allowed the INL Site to serve as an outdoor laboratory for environmental scientists to study evidence of at least 13,500 years of human land use and Idaho's native plants and wildlife in an intact and relatively undisturbed ecosystem. Because of the INL Site's established facilities, a security buffer that protects research, long-term records of environmental conditions, and partnerships with universities and industry, the Idaho National Environmental Research Park provides exceptional opportunities for research. 


\subsection{Sagebrush-Steppe Ecosystem Reserve}

The INL Site lies within the largest sagebrush-steppe region within North America. Sagebrush-steppe is a type of dry habitat characterized by sagebrush and other shrubs and short grasses. The National Biological Service identified the sagebrush-steppe ecosystem as critically endangered across its entire range in 1995. On July 17, 1999, the Secretary of Energy and representatives of the U.S. Fish and Wildlife Service (USFWS), BLM, and Idaho Department of Fish and Game designated a portion of the INL Site as the Sagebrush-Steppe Ecosystem Reserve. ${ }^{14}$ The Sagebrush-Steppe Ecosystem Reserve, which covers approximately $300 \mathrm{~km}^{2}$ or $115 \mathrm{mi}^{2}$ in the northwest corner of the INL Site, was designated to ensure this portion of the ecosystem receives special consideration. Figure 17 shows the location of the Sagebrush-Steppe Ecosystem Reserve at the INL Site. Because of the inherent ecological benefits of such a large tract of protected and relatively undisturbed habitat, the scientific community recognizes this acreage as providing an excellent opportunity for research.

BLM and DOE have prepared a management plan for the INL Sagebrush-Steppe Ecosystem Reserve with input from the Idaho Department of Fish and Game, USFWS, and Native American Tribes. The Sagebrush-Steppe Ecosystem Reserve is managed as a laboratory where all native ecosystem components, cultural resources, and Native American tribal values are conserved, yet opportunities for scientific investigation of the resources present on the INL Site are provided. The Sagebrush-Steppe Ecosystem Reserve Final Management Plan (2004) ${ }^{14}$ discusses wildfire suppression, livestock grazing, road management, weed control, and protection of cultural resources. The management plan identified four management goals that are used as a framework to facilitate long-term health of this unique ecosystem. The first goal identified in the management plan was addressed with the release of a Sensitive Animal Species Inventory, in November 2007, on the INL Sagebrush Steppe Ecosystem Reserve, which establishes "a baseline of resource data to identify and prioritize immediate needs for management adjustment."

\subsection{Agricultural Uses}

Up to 137,360 hectares $(340,000$ acres $)$ of the INL Site are leased for cattle and sheep grazing; grazing permits are administered by BLM. Grazing is not permitted within $0.8 \mathrm{~km}(0.5 \mathrm{mi})$ of any primary facility boundary or within $3.22 \mathrm{~km}$ ( 2 miles) of any nuclear facility. Figure 17 illustrates the current grazing boundaries at the INL Site. In addition, the U.S. Sheep Experiment Station uses 364 hectares (900 acres) as a winter feedlot for sheep. This area is located at the junction of Idaho State Highways 28 and 33.

\subsection{Permitted Public Use}

The INL Site provides an important habitat for big game. However, big game use of adjoining farmlands has resulted in depredation concerns. In an effort to control this situation and reduce crop damage caused by wild game on adjacent private agricultural lands, DOE cooperates with the Idaho Department of Fish and Game in allowing limited, controlled hunts for elk and antelope. These hunts, managed in accordance with an existing DOE/Idaho Department of Fish and Game memorandum of agreement, represent a form of limited and permitted public use of the INL Site. This use is restricted to certain species and specific locations (illustrated in Figure 17).

Thirty-four species observed at the INL Site are considered game species. Of these, waterfowl constitutes the largest number of species present. Waterfowl use wetland and riparian habitat associated with the Big Lost River and ponds or impoundments at INL Site facilities. However, the most common game species are pronghorn and mourning dove found in upland habitats.

The INL Site does not lie within any of the land boundaries established by the Fort Bridger Treaty of 1868. The provision in the Fort Bridger Treaty that allows the Shoshone-Bannock Tribes to hunt on unoccupied lands of the United States does not presently apply to any land upon which the INL Site is 
located because the entire INL Site is considered to be occupied by DOE. The Shoshone-Bannock Tribes and DOE have an agreement-in-principle that encourages regular interactions between INL and the Tribes on issues of mutual concern. The Tribes also have a memorandum of agreement for special tribal access to the area around Middle Butte Cave on INL.

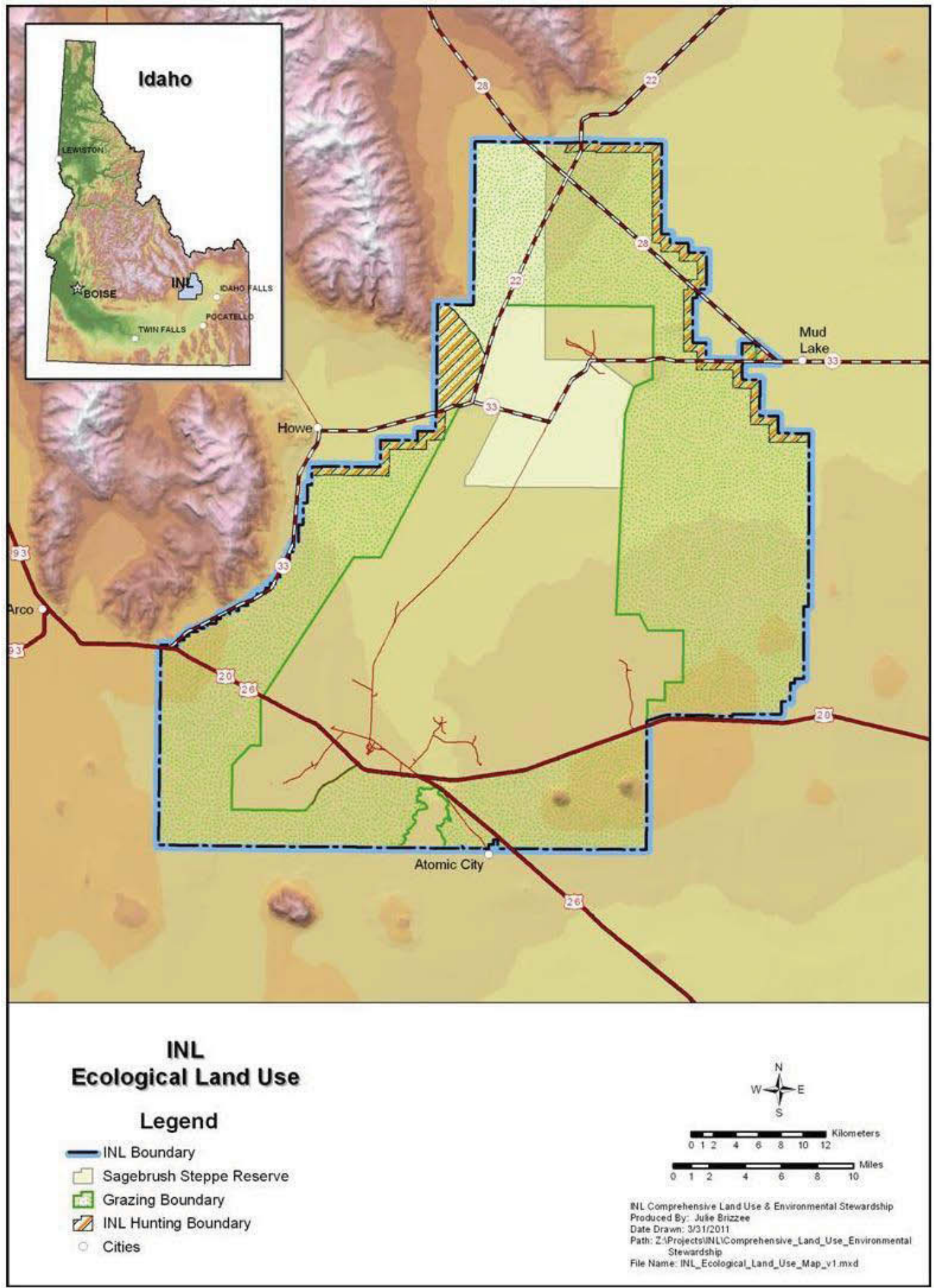

Figure 17. Idaho National Laboratory ecological land use. 


\subsection{Mineral Rights Ownership}

The subsurface mineral rights associated with the INL Site are managed by BLM. Additional information regarding management of these resources is available from the local Idaho Falls BLM office.

\subsection{Topography}

Figure 18 details the topography of the INL Site. The Lost River and Lemhi Ranges and the mouths of the valleys of the Big Lost and Little Lost Rivers bound the INL Site on the west and northwest. On the north, the mouth of the Birch Creek Valley and the southern tip of the Beaverhead Mountains of the Bitterroot Range bound the INL Site on the Idaho-Montana border. Features to the south and east of the site are similar to those found on the site, characterized by relatively flat topography punctuated by several prominent volcanic buttes and numerous basalt flows. The average surface elevation on the INL Site is approximately $1,500 \mathrm{~m}(5,000 \mathrm{ft})$ above sea level, although isolated buttes reach elevations of nearly $2,000 \mathrm{~m}(6,600 \mathrm{ft})$.

Peaks to the immediate north and west of the site borders approach 3,300 $\mathrm{m}(11,000 \mathrm{ft})$. The predominant topographic features within the boundaries of the INL Site are the Twin Buttes (Middle and East Buttes). Big Southern Butte, located approximately $4 \mathrm{~km}$ (2.5 miles) south of the site boundary, is the tallest surface feature within the Snake River Plain, reaching an elevation of 2,300 m (7,600 ft). These buttes provide the most conspicuous evidence of the volcanic origin of the Snake River Plain, although numerous smaller buttes, cinder cones, lava outcrops, and lava tubes may be found in the area.

\subsection{Bedrock Geology}

Geologically, the Snake River Plain is thought to have been formed by the southwestward migration of the North American tectonic plate over a stationary hot spot in the earth's mantle, forming a linear volcanic province extending from Yellowstone National Park to southwestern Idaho. ${ }^{15}$ Explosive volcanic activity in the area between 4 and 7 million years ago formed silicic lava flows and pyroclastic deposits extending to depths of at least $2,500 \mathrm{~m}(8,200 \mathrm{ft})$ below the surface. ${ }^{16}$ These rhyolite rocks underlie the more recent basalt lava flows, which are interbedded with sediment, thus forming a highly permeable aquifer. ${ }^{17}$ These features are illustrated in Figure 19.

The most recent basalt flow in the INL Site area was the Cerro Grande flow, which occurred approximately 13,000 years ago. ${ }^{18}$ In contrast, the Hell's Half-Acre flow immediately to the east of the INL Site is only about 5,200 years old, and the flows at the nearby Craters of the Moon National Monument are as recent as 2,100 years old. The much older basalt plains characteristic of the southern portion of the INL Site are between 200,000 and 730,000 years old. ${ }^{12}$ Basalt on the northern portion of the INL Site is at least a million years old.

In addition to the locally generated basalt outcrops and flows, the principle surface materials at the INL Site include alluvium, lakebed or lacustrine sediment, slope wash sediment and talus, silicic volcanic rocks, and sedimentary rocks.

\subsection{Surface Soils}

Despite the fact that the subsurface geology of the INL Site is dominated by basalt, most soils found on the INL Site are derived from older silicic volcanic and Paleozoic rocks from the surrounding mountains. These materials are deposited as sediment transported to the area by wind, water, or gravity.

A thin layer of eolian, or wind-borne sediment, covers virtually all of the INL Site area. The soils formed by this sediment ranges in texture from the fine-grained, wind-blown glacial loess left behind by retreating glaciers during the Pleistocene to sand believed to have originated from the Big Lost River and the Snake River and from the shorelines of the ancient Lake Terreton. Because of the uneven, broken

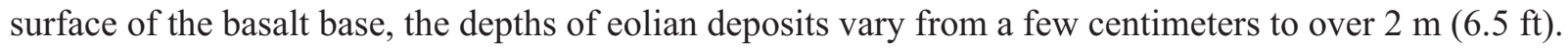




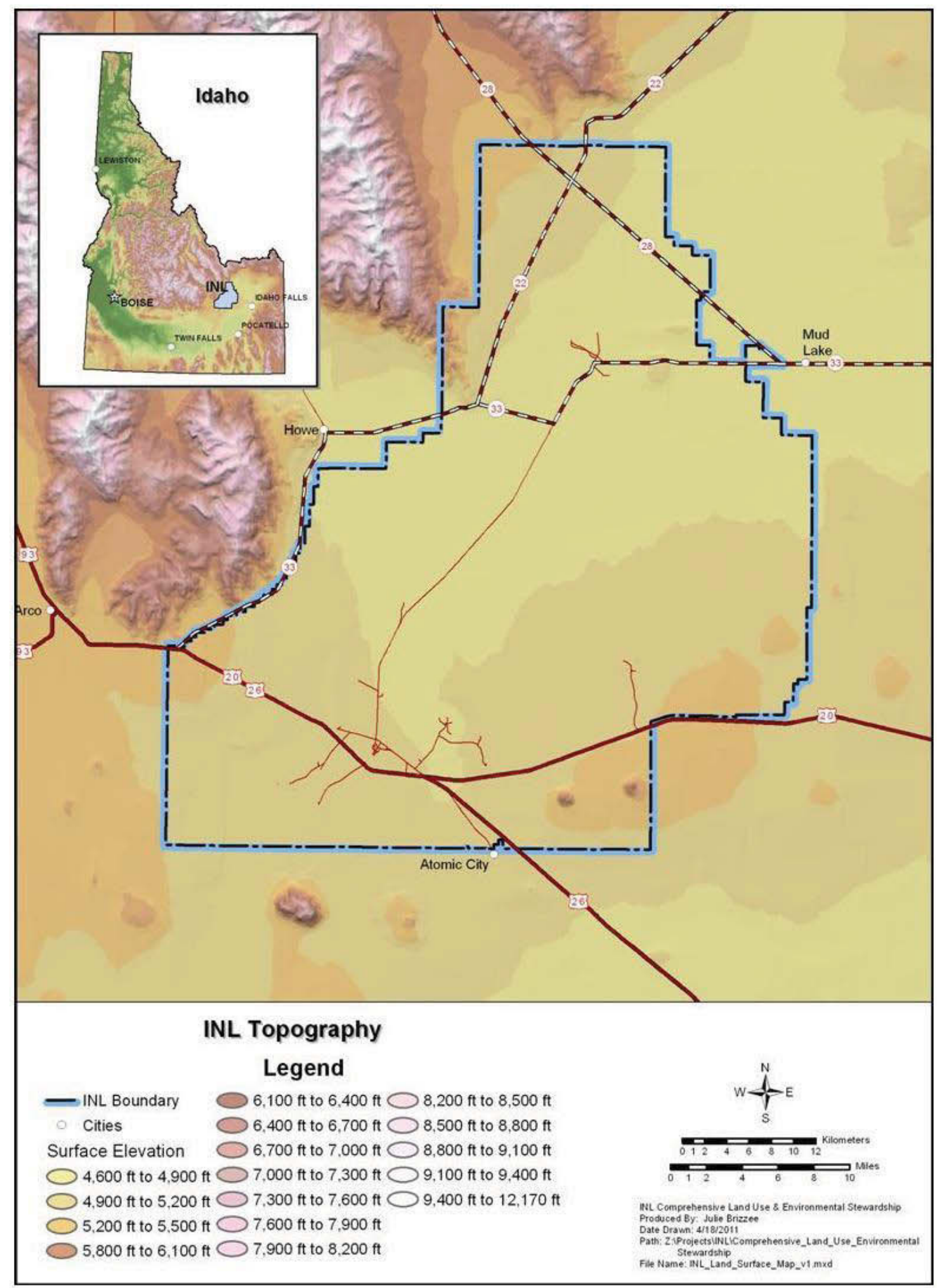

Figure 18. Idaho National Laboratory topography. 


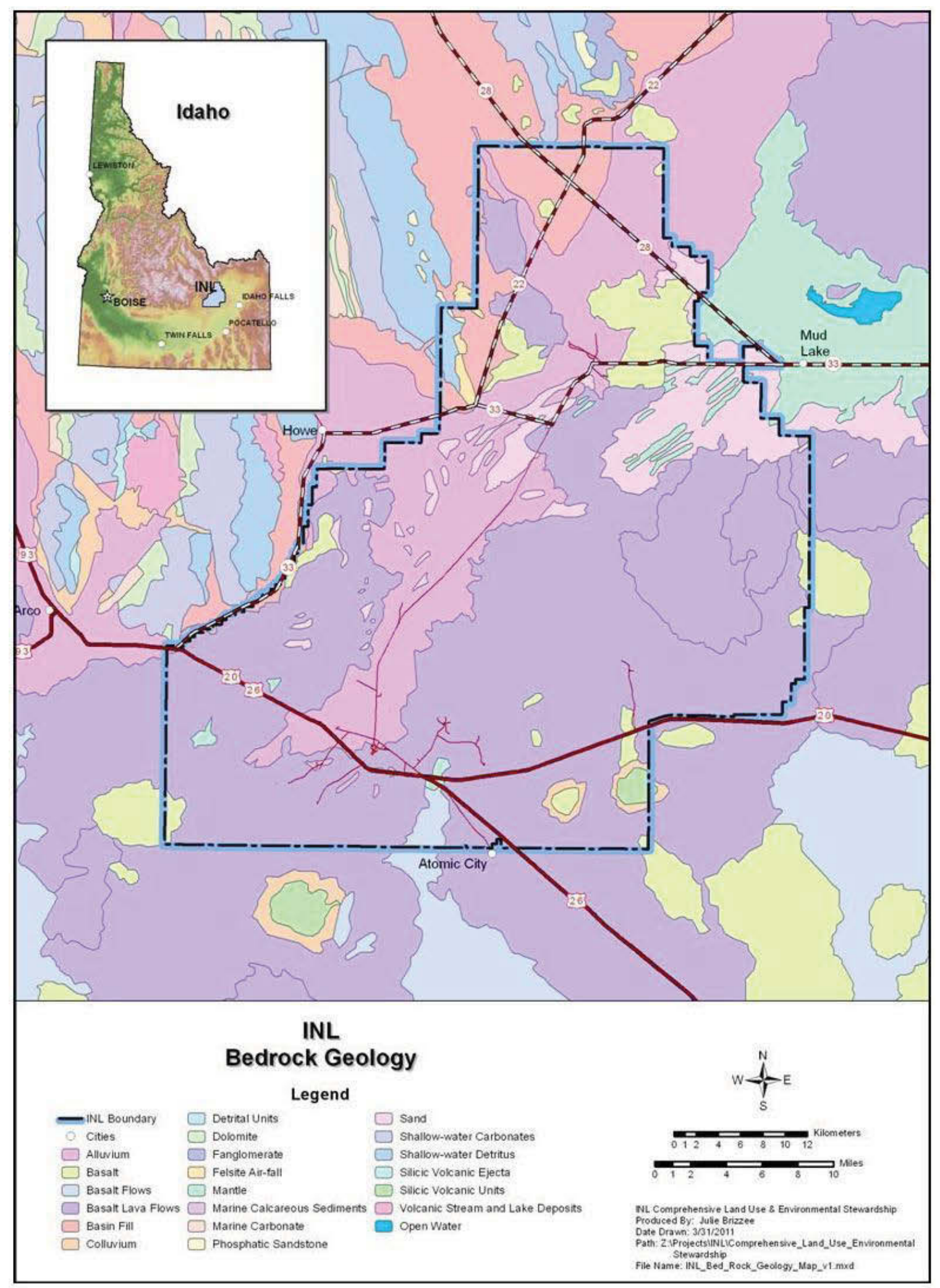

Figure 19. Idaho National Laboratory bedrock geology. 
In addition to this long-term eolian deposition, the INL Site and surrounding areas have been subject to at least two distinct episodes of major loess deposition during the past 200,000 years, with the most recent episode occurring some 10,000 years ago. ${ }^{12}$ Soils derived from these two major depositional events are markedly distinct; subsoils in the younger deposits contain high amounts of carbonates accumulated over many years of low rainfall and high evaporation rates, whereas soils from the older loess deposits developed during periods of higher precipitation. In these soils, salts have been leached out of the subsoil, and fine particles (clays) have been deposited from the surface to the subsoil. Subsoil horizons of the older soil have relatively high amounts of clay rather than carbonates.

Alluvial soils are the result of deposition of water-borne sediment. On the INL Site, most alluvial soils are found on the western and northern portions of the site, specifically near the Big Lost River floodplain, on the small alluvial fans below the bordering mountains, and within the large alluvial fan of Birch Creek. ${ }^{19}$ The Big Lost River and Birch Creek, as well as the Little Lost River, originally fed the ancient Lake Terreton, which occupied much of the northern part of the INL Site. Because the area is a closed basin, water cannot flow out of the area. Loss of water is through downward percolation into the aquifer or via evaporation, both of which leave sediment in place.

The areas of the basin where water from the Big Lost River historically collected are referred to as the Big Lost River Sinks. Historically, water entering the INL Site from the Big Lost River first reached the Big Lost River Sinks area. In times of heavy flow, water was able to flow from the Big Lost River Sinks into a series of three playas, marking the bottom of the undrained desert basin - portions of the ancient bed of Lake Terreton. Similarly, water from Birch Creek naturally flowed into a fourth playa, also known as the Birch Creek Playa, near TAN. In very heavy runoff years, the Birch Creek playa connected with the third Big Lost River playa. The Little Lost River also historically terminated in a series of sinks and playas, but these are located just to the northwest of the INL Site boundary.

All of these sink and playa areas contain substantial alluvial deposits, including bars, spits, and hooks from the ancient Lake Terreton that are well preserved on the modern landscape near TAN. These alluvial deposits are generally quite saline and support a variety of salt-tolerant plant species. Sediment in the playas and lakebeds of the ancient Lake Terreton generally is fine-textured loams or clay loams with relatively high clay content. Playa or desert lake basins are characteristic of another major surface soil type at the INL Site. Playas, in general, are attractive for development because of the deep silty deposits. Soils from the playas may be easily excavated for fill materials, but care must be taken to determine the shrink-swell capacity.

Colluvial soils formed from sediment originating from bordering mountains are found along the base of the mountain slopes on the western edge of the INL Site and surrounding the East and Middle Buttes. Generally, the colluvial soils in these deposits are gravelly. Very little information is available regarding the soils within these deposits, and the total area within the INL Site that is dominated by colluvial soils is small. Although a comprehensive survey of the soils at the INL Site has not been conducted, information from county surveys and numerous other sources has been compiled recently. ${ }^{20}$ This compendium indicates that most INL Site soils are Aridisols, with Calciorthids being the most common great group; Entisols, namely Torriorthents and Torrifluvents; and Mollisols, including Calcixerolls and Haploxerolls. A general soil map of the INL Site (Figure 20) depicts the distribution of these various surface soils.

\subsection{Water Resources}

\subsubsection{Surface Hydrology}

Using the United States Geological Survey's surface water classification scheme, the INL Site straddles portions of six (possibly seven) watersheds (Figure 21). These watersheds include American Falls, Big Lost River, Birch Creek, Idaho Falls, Little Lost River, Medicine Lodge, and possibly a small portion of Lake Walcott (see Table 1). Of these watersheds, only four contain significant surface water bodies that flow onto or near the INL Site, including the Big Lost River, Birch Creek, Little Lost River, 
and Medicine Lodge watersheds. All surface water within them is lost to evapotranspiration or via infiltration to their local aquifers and the regional Eastern Snake River Plain Aquifer near or beneath the INL Site.

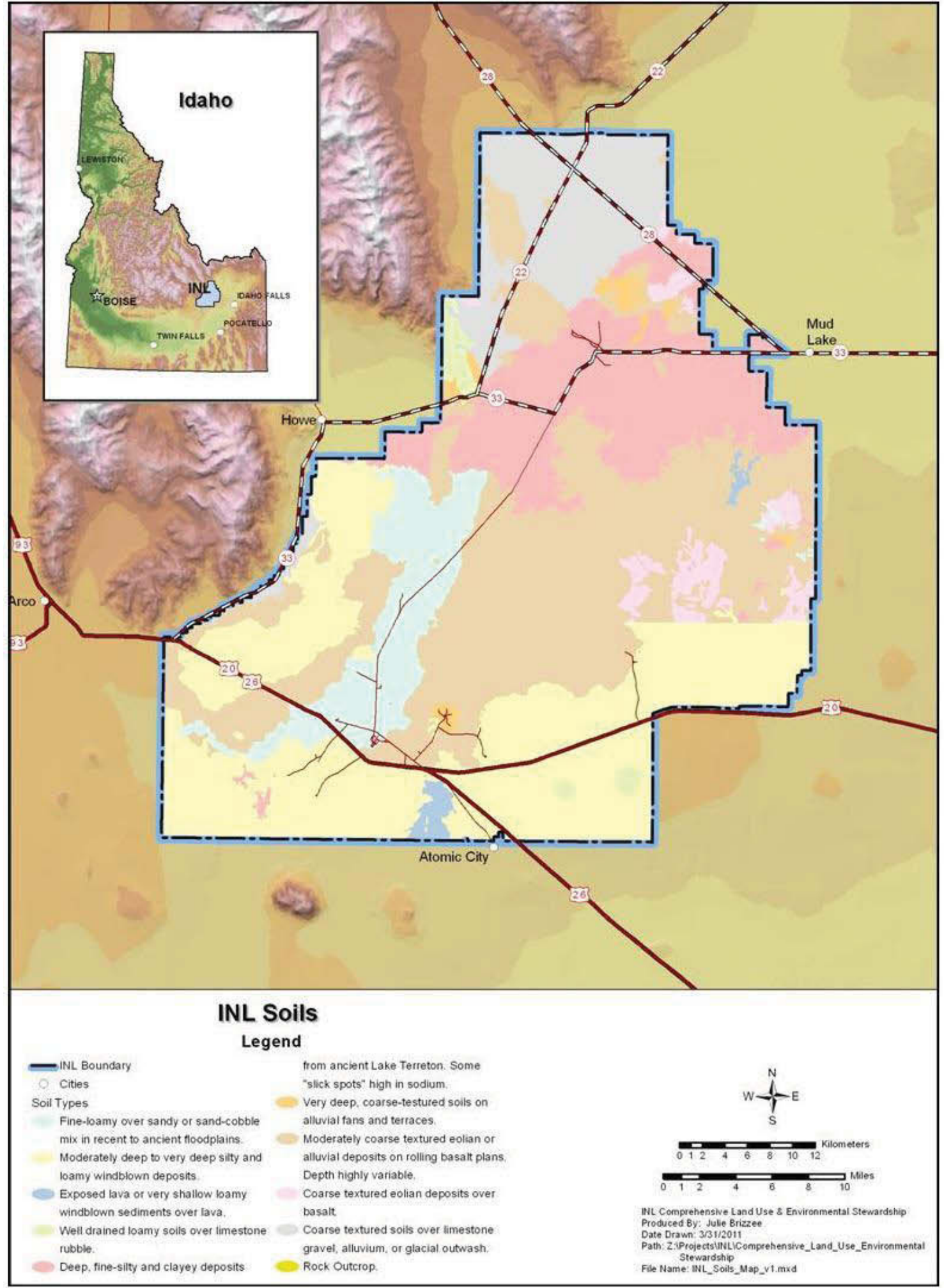

Figure 20. Idaho National Laboratory soils. 


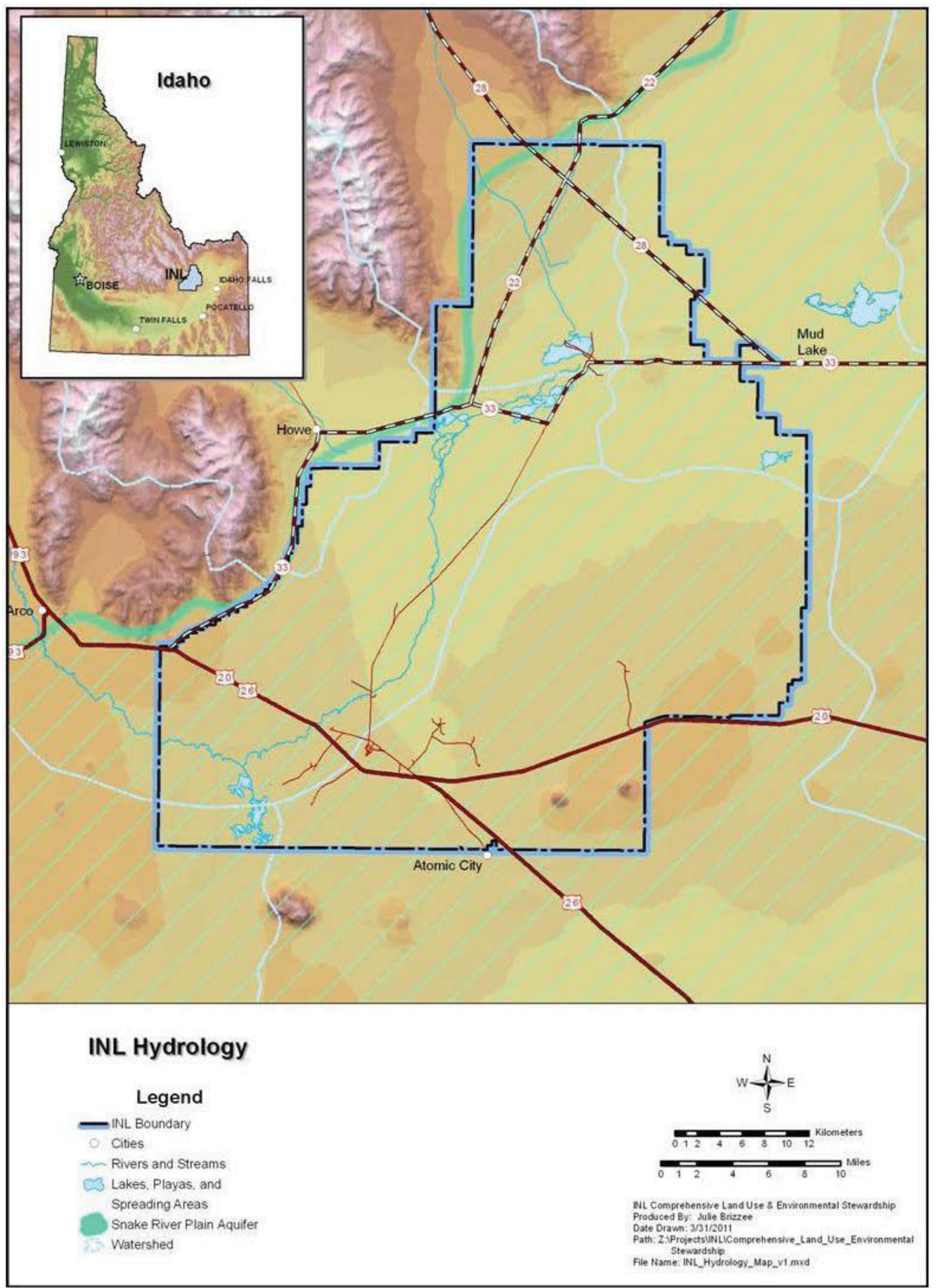

Figure 21. Idaho National Laboratory hydrology. 
Table 1. Watersheds and aquifers directly associated with the Idaho National Laboratory Site.

\begin{tabular}{|l|c|c|}
\hline \multicolumn{1}{|c|}{ Watershed Name } & Drainage at INL (\%) & Aquifer Name $^{\mathrm{a}}$ \\
\hline American Falls & 39 & Snake River Plain \\
\hline \multirow{3}{*}{ Big Lost } & \multirow{3}{*}{34} & Big Lost \\
\cline { 2 - 3 } & & Copper Basin \\
\hline Birch Creek & 14 & Birch Creek \\
\hline \multirow{2}{*}{ Medicine Lodge } & 9 & Snake River Plain \\
\hline \multirow{2}{*}{ Little Lost } & 3 & Snake River Plain \\
\hline Idaho Falls & 1 & Little Lost \\
\hline Lake Walcott & b & Snake River Plain \\
\hline $\begin{array}{l}\text { a. Aquifer names and numbers from Graham and Campbell (1981). } \\
\text { b. It is unclear whether Lake Walcott intersects the INL Site. }\end{array}$ \\
\cline { 2 - 3 }
\end{tabular}

The American Falls watershed drains approximately 39\% of the INL Site, primarily around MFC and the Power Burst Facility. It is a relatively large watershed that straddles the north and south sides of the Snake River.

The Big Lost watershed is a $4,921-\mathrm{km}^{2}\left(1,900-\mathrm{mi}^{2}\right)$ watershed that drains approximately $34 \%$ of the INL Site. Flows in the Big Lost River are usually diminished by evaporation, irrigation diversions, and infiltration losses along the river channel. Generally, Big Lost River flows do not reach the INL Site boundary during periods of low runoff. However, during periods of medium to high runoff, the river flows onto the INL Site. Depending on the amount of water flowing in the river, a portion or all the flows can be diverted to the INL Site Diversion System. Flows that remain in the river channel then flow northeastwardly in a concave arch toward its terminus in the Big Lost River playas near TAN. The Big Lost River is important to the INL Site because most major INL Site facilities are located along the Big Lost River corridor.

The Birch Creek watershed drains approximately $14 \%$ of the INL Site. It is a long, thin $1,792-\mathrm{km}^{2}$ $\left(692-\mathrm{mi}^{2}\right)$ watershed originating north of and incorporating TAN. Historically, Birch Creek flows terminated in the Birch Creek Playas; however, in 1969, INL constructed some channels and began diverting the water to several gravel pits east of TAN. Several TAN facilities are located in this watershed.

The Medicine Lodge watershed drains approximately $9 \%$ of the INL Site. It is a long, thin 2,466-km² $\left(952-\mathrm{mi}^{2}\right)$ watershed east of TAN. The most significant surface water resource in this unit is Mud Lake, just north of the town of Terreton and east of the INL Site. No permanent streams are on or near the INL Site, and no INL Site facilities are located in this watershed.

The Little Lost River watershed drains approximately $3 \%$ of the INL Site. It is a $2,479-\mathrm{km}^{2}\left(957-\mathrm{mi}^{2}\right)$ watershed originating on the eastern slope of the Lost River Mountains and the western slope of the Lemhi Mountains. This watershed does not include any INL Site facilities, and the Little Lost River is not known to have flowed onto the INL Site.

The Idaho Falls watershed drains approximately $1 \%$ of the INL Site east/southeast of MFC. It is a $2,953-\mathrm{km}^{2}\left(1,140-\mathrm{mi}^{2}\right)$ watershed that straddles the east and west sides of the Snake River. No INL Site facilities are located in this watershed.

The Lake Walcott watershed may or may not drain a portion of the INL Site. The Lake Walcott watershed is a relatively large watershed that straddles the north and south sides of the Snake River. If it 
does intersect the INL Site boundary, only a very minor portion (less than $1 \%$ ) of it would be associated with the INL Site. No INL Site facilities are located in this watershed.

\subsubsection{Wetlands}

The Environmental Protection Agency defines wetlands as "areas inundated or saturated by surface or groundwater at a frequency and duration sufficient to support, and that under normal circumstances do support, a prevalence of vegetation typically adapted for life in saturated soil conditions" (40 CFR $230.3(\mathrm{t}))^{22}$

The USFWS, as part of a 1992 preliminary survey, conducted an evaluation of aquatic habitats at the INL Site for the National Wetlands Inventory. This inventory identified and mapped approximately 135 areas within the boundaries of the INL Site. Of these areas, 121 INL Site wetlands were surveyed, grouped into five wetland categories (i.e., palustrine and lacustrine, riverine, manmade, unmapped, and unclassified). Jurisdictional wetlands, governed by the Clean Water Act (33 USC 1251-1376), ${ }^{23}$ are those wetlands that exhibit: (1) a prevalence of hydrophytic plants, (2) hydrological conditions suited to such plants, and (3) the presence of hydric soils. The only area of the INL Site identified as potentially jurisdictional wetlands is the Big Lost River Sinks. Additional information concerning this mapping can be obtained in A Preliminary Survey of the National Wetlands Inventory as Mapped for the Idaho National Engineering Laboratory. ${ }^{24}$

\subsubsection{Groundwater Hydrology}

Five aquifers are associated with the Site: the Big Lost River Valley Aquifer, Birch Creek Valley Aquifer, Copper Basin Aquifer, Little Lost River Valley Aquifer, and the Eastern Snake River Plain Aquifer. The Big Lost River, Little Lost River, Birch Creek, and Medicine Lodge aquifers are tributary to the Eastern Snake River Plain Aquifer. The exact boundaries between these tributary aquifers and the Eastern Snake River Plain Aquifer are not well known.

The Eastern Snake River Plain Aquifer is the most significant aquifer relative to the INL Site because it underlies the vast majority of the INL Site. All of the water used by the INL Site is supplied by the Eastern Snake River Plain Aquifer in accordance with a Federal Reserve Water Right negotiated between DOE and the State of Idaho. ${ }^{25}$ The INL Site is permitted a water-pumping capacity of $80 \mathrm{ft}^{3} / \mathrm{s}$ and a maximum water consumption of 35,000 acre-ft per year. However, on average, the INL Site withdraws approximately 6,229 acre-ft per year. About $65 \%$ of these withdrawals are eventually returned to the aquifer via percolation. Consequently, the annual consumptive usage of water withdrawn from the aquifer is about 2,200 acre-ft per year.

The Environmental Protection Agency has designated the Eastern Snake River Plain Aquifer as a sole-source aquifer, meaning that it supplies at least $50 \%$ of the drinking water consumed in the area overlying the aquifer. Under the Sole-Source Aquifer Program, ${ }^{26}$ the Environmental Protection Agency reviews all projects for which federal financial assistance has been requested. However, this designation does not affect the INL Site because it is operated through direct federal funding, not through federal financial assistance projects. Groundwater protection requirements of the Safe Drinking Water Act are met through negotiated compliance authorized under other provisions of the law (e.g., CERCLA).

The depth to the Eastern Snake River Plain Aquifer below the INL Site varies from about $61 \mathrm{~m}$ $(200 \mathrm{ft})$ in the northern portion near TAN to more than $274 \mathrm{~m}(900 \mathrm{ft})$ at the southwestern corner of the Site near RWMC. Figure 22 illustrates the groundwater contours beneath the INL Site.

In addition to the regional aquifer, "perched water" or groundwater that is separated from the underlying regional aquifer by an interval of unsaturated rock or sediment exists at numerous areas beneath the Site. Water from these zones flows downward through low-permeability layers of fine-grained sediment and basalt flows to the aquifer. Perched water zones are known to exist below the 
Big Lost River and below wastewater discharge operations at INTEC, the ATR Complex, TAN, NRF, and MFC.

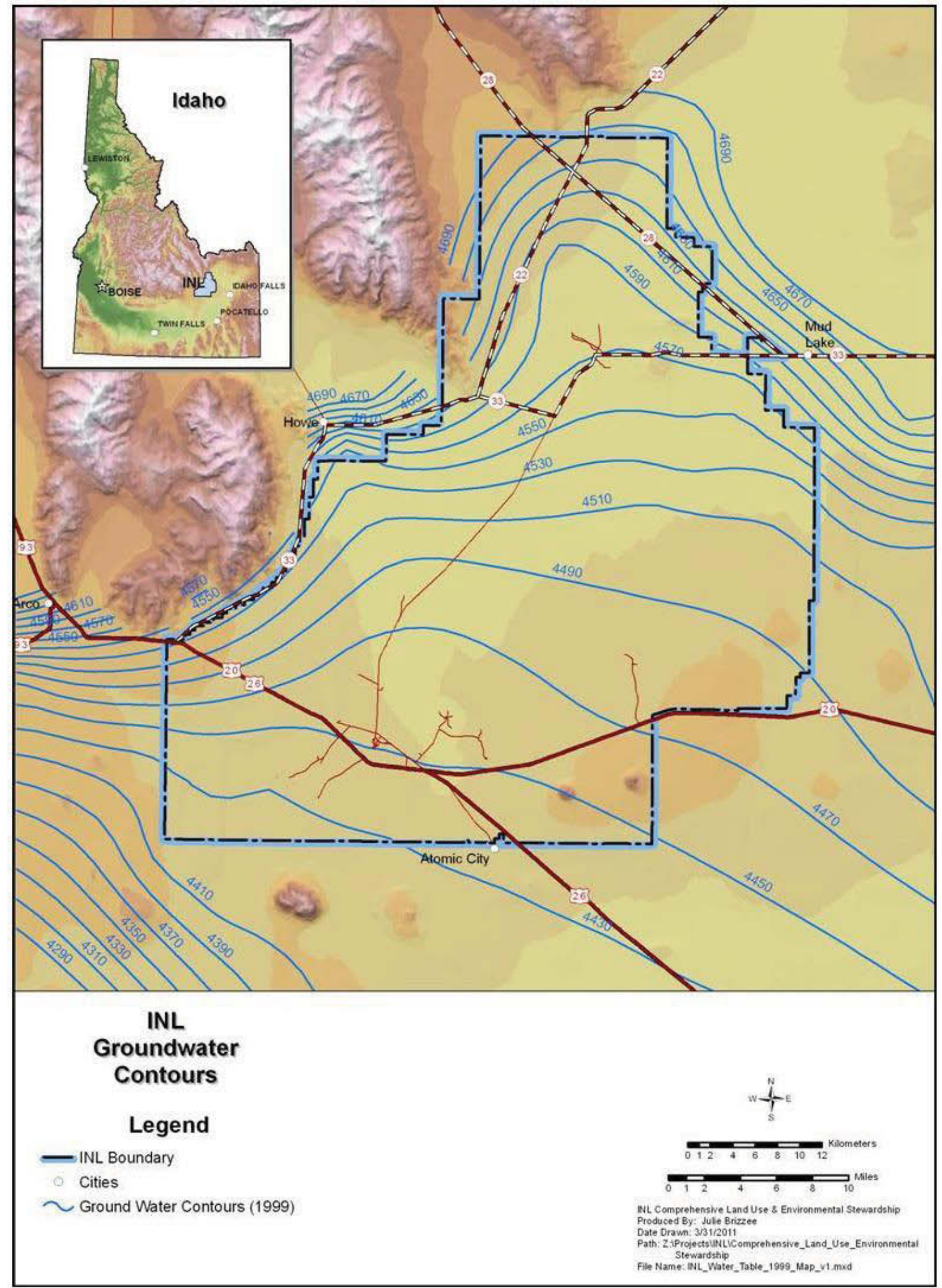

Figure 22. Idaho National Laboratory groundwater contours. 


\subsection{Biota}

\subsubsection{Flora}

The natural vegetation at the INL Site primarily consists of a shrub overstory with an understory of perennial grasses and forbs. Most vegetation communities within the site boundaries are dominated by various species or subspecies of sagebrush, although some communities that are dominated by saltbush, juniper, crested wheatgrass, and Indian rice grass are present and distributed throughout the INL Site. The INL Site supports over 420 species of flowering plants. ${ }^{27}$ Considerable information on vegetation communities and plant species found on the INL Site are available elsewhere, including the web-based INL Environmental Surveillance, Education, and Research Program site.

The INL Site occupies one of the largest tracts of relatively undisturbed sagebrush-steppe rangeland in the United States, with the most common shrub on the INL Site being Wyoming big sagebrush, although basin big sagebrush may dominate or be codominant with Wyoming big sagebrush on sites having deep soils or sand accumulations. ${ }^{28}$ Wyoming big sagebrush communities occupy most of the central portions of the INL Site. Green rabbitbrush is the next most abundant shrub, and other common shrubs include winterfat, spiny hopsage, gray rabbitbrush, broom snakeweed, and horsebrush. Communities dominated by Utah juniper and three-tipped sagebrush, black sagebrush, or both are limited to areas along the INL Site periphery, specifically on the slope of the buttes and on the foothills of adjacent mountain ranges to the northwest. Salt-desert shrub communities may be found on the sediment in the sinks and playas associated with the Big Lost River and Birch Creek. These communities are dominated by shadscale, Nuttall saltbush, or winterfat.

The understory grasses include natives such as thick-spiked wheatgrass, bottlebrush squirreltail, Indian rice grass, needle-and-thread grass, and Nevada bluegrass. Creeping wild rye and western wheatgrass may be locally abundant. Communities dominated by basin wild rye are common in depressions between lava ridges and in other areas having deep soils. Bluebunch wheatgrass is common at slightly higher elevations southwest and east of the INL Site.

Vegetation communities within the INL Site boundaries contain an unusually high diversity of forbs largely due to the exclusion of livestock grazing common throughout the sagebrush-steppe region. Forb species are numerous, but not abundant in many areas. Common forbs include tapertip hawksbeard, Hood's phlox, prickly phlox, hoary false yarrow, globe-mallow, evening primrose, bastard toadflax and various paintbrushes, buckwheats, lupines, milkvetches, and mustards.

A system of sinks and playas of the Big and Little Lost Rivers and Birch Creek are believed to have once supported an extensive, diverse, and unique wetland system. However, only minimal surveys of the presence and abundance of plant species have ever been conducted in this area, including two surveys in 1995 and 1997 conducted by an INL team inventorying plants and aquatic invertebrates in the area.

A total of 11 Idaho noxious weeds have been identified on the INL Site and several other non-native species also are present. Non-native species are quick to colonize new disturbance and successfully compete with native species, making them difficult to eradicate once present. Exotic plant species (such as cheatgrass and Russian thistle) that are well established, particularly within disturbed areas, may be altering the overall structure of the plant communities in the region, and, in the case of cheatgrass, also may be dramatically altering the fire regime. Crested wheatgrass, a European bunchgrass seeded in the late 1950s, dominates many disturbed areas where it was used to provide cover and to hold soils (Figure 23). 


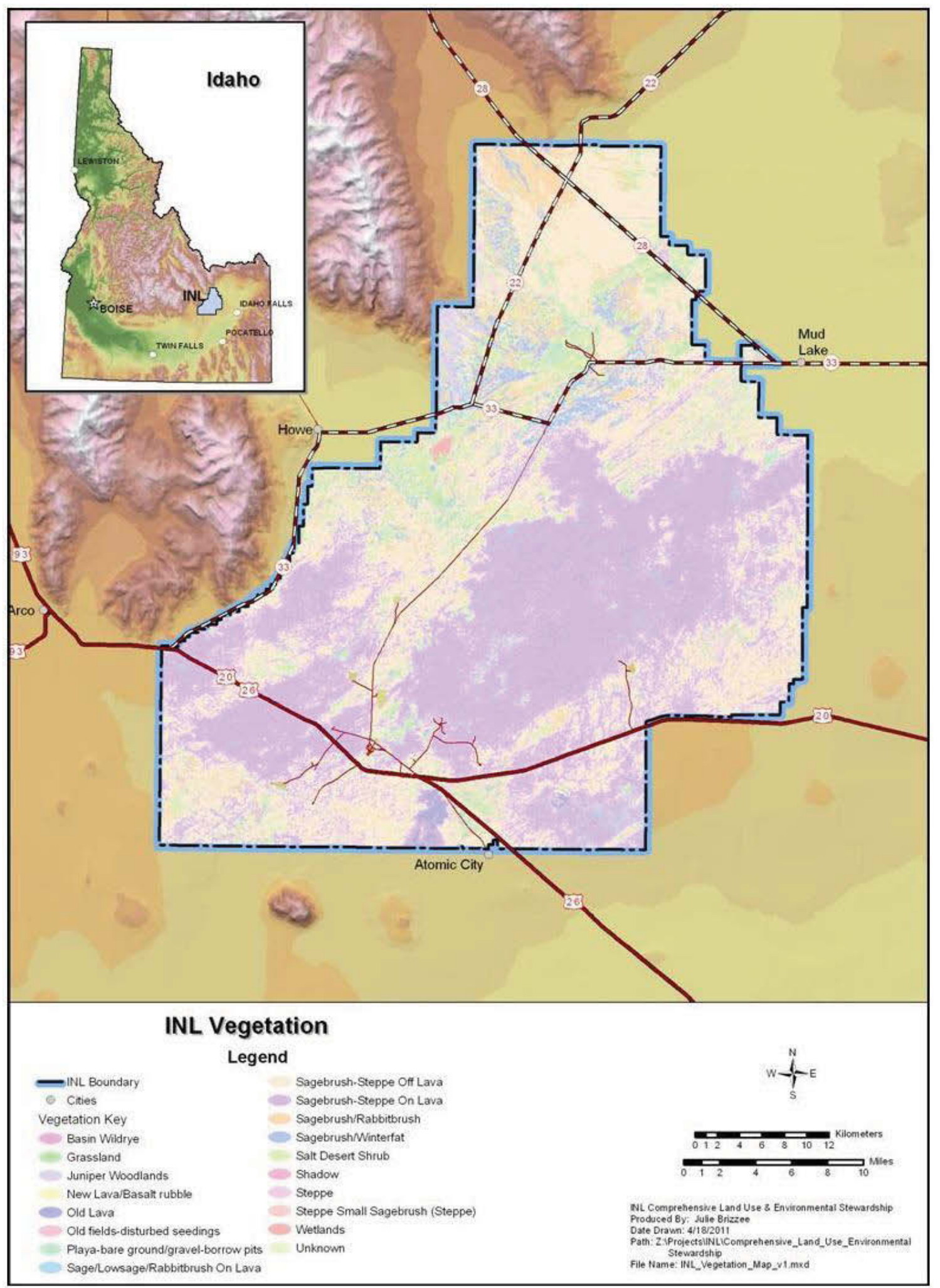

Figure 23. Idaho National Laboratory vegetation.

4.15.1.1 Special Status Plants. The USFWS provides a list, by county, of threatened and endangered species and other species of concern for the State of Idaho. The most recent USFWS list 
(December 2010) ${ }^{29}$ includes one threatened plant species that may occur within the five counties that encompass the site: Ute ladies'-tresses (Spiranthese diluvialis). In addition, there are several sensitive plant species that may be present on the INL Site. ${ }^{30}$

\subsubsection{Fauna}

Estimates of the total number of species of vertebrate fauna found on the INL Site vary. Perhaps the most reliable information on vertebrate fauna on the INL Site is provided by the INL Environmental Surveillance, Education, and Research Program, ${ }^{31}$ which describes some 211 vertebrate species (i.e., 5 fish, 1 amphibian, 9 reptile, 37 mammal, and 159 bird species) as having been documented on the INL Site. Of these species, 56 are considered to be year-round residents, whereas the rest are partial-year residents that were observed during specific seasons or during migration. Most of the migratory species are birds. An additional nine fish, five amphibian, five reptile, 13 bird, and 14 mammal species are considered as possibly occurring at the site, because portions of their range overlap the INL Site area or they have been reported within $30 \mathrm{~km}$ (18 miles) of the INL Site. However, no verified observations of these species have been reported on the INL Site.

Fish species reported on the INL Site are limited to the Big Lost River during years when water flow is sufficient. ${ }^{32}$ However, periods of drought and upstream water diversion for agricultural and flood-prevention purposes has severely restricted the flow of the Big Lost River on the INL Site, thereby restricting the presence of native fish species. Similarly, the Great Basin spadefoot toad, the INL Site's only reported resident amphibian, is limited by water flow in the Big Lost River. Reptiles include five species of snake, three species of lizards, and the western skink.

Birds represent the largest group of vertebrates found on the INL Site, although as pointed out above, many bird species are seasonal residents. Raptors, songbirds, and waterfowl are all well represented and comprise important ecological components of the sagebrush-steppe community. The INL Site is inhabited by 14 species of sparrows and allies, six species of swallows, 20 species of ducks and geese, and 24 species of raptors. ${ }^{28}$ Among these species is the bald eagle, which is seen on or near the INL Site during winter. Sage-grouse is another species of importance that is present on the INL Site (see Section 4.15.2.1).

Although most of the 37 mammal species reported on the INL Site are small mammals, several important large mammals (such as mule deer) are present. Approximately 30\% of Idaho's pronghorn populations use the INL Site and surrounding areas for winter range. ${ }^{33}$ In addition, a small population of elk has become resident on the INL Site. Some small mammal species (such as the black-tailed jackrabbit) exhibit large population fluctuations and influence the abundance, reproduction, and migration of predators such as the coyote, bobcat, and raptors. Other observed predators include mountain lions and badgers.

Several vertebrate species are considered to be sagebrush obligates (i.e., they live only in sagebrush communities). These sagebrush obligates include sage-grouse, sage sparrow, and pygmy rabbit. Rock outcroppings associated with these communities also provide habitat for species such as bats and wood rats. Grasslands serve as habitat for species that include the western meadowlark and mule deer. Facility structures at the INL Site also provide important wildlife habitat. Buildings, lawns, ornamental vegetation, and ponds are used by a number of species such as waterfowl, raptors, rabbits, and bats. Aquatic vertebrates are supported year-round by habitat provided by facility treatment ponds, waste ponds, and facility drainages. ${ }^{34}$

In 1995 and 1997, an INL team conducted surveys in the area of the INL Site that contains a system of sinks and playas of the Big and Little Lost Rivers and Birch Creek. Although by no means comprehensive, the field team observed 18 species of waterfowl and shorebirds (including over 500 ducks, some with broods) and several other bird species, including two peregrine falcons. Thousands of ephemeral Great Basin spadefoot toads were observed, as were invertebrates representing many 
different orders. Although remnants of these systems remain, the long-term impact of the various water diversion systems on the aquatic communities is uncertain.

The biological diversity of invertebrate fauna at the INL Site has not been investigated extensively; however, 740 insect species have been collected and identified at the INL Site. The harvester ant, in particular, has received attention during the past decade because of its general importance in desert ecosystem nutrient cycling and energy flow. ${ }^{35,36}$ At the nearby Craters of the Moon National Monument, where a thorough inventory of invertebrates has been obtained, 2,064 species were found; therefore, many more insect species may be present at the INL Site.

4.15.2.1 Special Status Wildlife. The USFWS provides a list, by county, of threatened and endangered species and other species of concern for the State of Idaho. The most recent USFWS list (May 9, 2011) includes two threatened and endangered species and three candidate species that may occur within the five counties that encompass the INL Site. ${ }^{26}$ The Canada lynx (Lynx canadensis) and the grizzly bear (Ursus arctos horribilus) are threatened species. Neither are expected to be present on the INL Site. The gray wolf (Canis lupus) was delisted on May 5, 2011, and is no longer afforded protection under the Endangered Species Act in Idaho; wolf populations in Idaho are managed by the State. Greater sage-grouse (Centrocercus urophasiunus), yellow-billed cuckoo (Coccyzus americanus), and the wolverine (Gulo gulo) are candidate species. Sage-grouse are generally considered obligates of the sagebrush-steppe system, requiring sagebrush for nesting, winter feeding, and shelter from weather and predators throughout the year. Sage-grouse are abundant at the INL Site. The yellow-billed cuckoo is a riparian-obligate species and is primarily associated with willow-cottonwood riparian forest.

Several other animal species were designated as sensitive that may be present on the INL Site. The bald eagle (Haliaeetus leucocephalus) was delisted in 2007, but is still protected under the Bald and Golden Eagle Protection Act. This species often winters in the Little Lost River Valley just north of the INL Site and several have been known to winter on the INL Site. The American peregrine falcon (Falco peregrinus) (delisted, but being monitored) has been observed infrequently on the northern portion of the INL Site.

Among the mammal species recognized by other agencies that might be found on the INL Site are Merriam's shrew (Sorex merriami), pygmy rabbit (Brachylagus idahoensis), bobcat (Lynx rufus), Townsend's big-eared bat (Corynorhinus townsendii), long-eared myotis (Myotis evotis), and small-footed myotis (Myotis subulatus). Bird species of concern include ferruginous hawk (Buteo regalis), long-billed curlew (Numenius americanus), northern goshawk (Accipiter gentilis), ferruginous hawk (Buteo regalis), osprey (Pandion haliaetus), gyrfalcon (Falco rusticolus), merlin (Falco columbarius), white-faced ibis (Plegadis chihi), long-billed curlew (Numenius americanus), burrowing owl (Athene cunicularia), prairie falcon (Falco mexicanus), and loggerhead shrike (Lanius ludovicianus). The northern sagebrush lizard (Sceloporous graciosus) is the single reptile on the USFWS list. ${ }^{29}$

\subsection{Cultural Resources}

The INL Site is home to a rich cultural heritage spanning at least 13,500 years of human occupation in southeastern Idaho. Several types of cultural resources exist across the landscape, including prehistoric and historic archaeological sites and artifacts; sites and artifacts of importance to the Shoshone-Bannock Tribes and others, such as the California and Oregon Trail Association; and historic architectural properties from the World War II timeframe. Resources representing America's pioneering nuclear era, including structures, buildings, objects, artifacts, and documents, also are present. Natural landforms and native plants and animals of the INL region also may be of traditional importance to Native Americans, and, although rare, human burials have been found on the INL Site and are of special importance. DOE allows access to certain areas of the INL Site to Shoshone-Bannock tribal members for activities related to the maintenance of tribal heritage, education of tribal members, and exercise of traditional cultural activities. 
The thousands of prehistoric archaeological sites within the INL Site boundaries range in age from more than 13,500 to 150 years old. Evidence of homesteads, stage stations, irrigation attempts, and trails also are extant. The INL Cultural Resource Management archives include documentation of nearly 3,000 archaeological resources and nearly 300 historic buildings and other structures, and the newly established INL Archive Center houses artifacts such as engineering and architectural drawings, 16-mm films, and photographic negatives. ${ }^{37}$ DOE-ID is tasked by law with managing this important cultural heritage in accordance with federal and state requirements and internal orders and directives. ${ }^{38} \mathrm{INL}$ is committed to protecting and preserving cultural resources across the site.

Strategies for the effective management of INL Site cultural resources have been developed in conjunction with pertinent INL programs and are detailed in DOE-ID's Cultural Resource Management Plan. ${ }^{39}$ A tailored approach to management of these resources and compliance with applicable federal and state law are included in the INL Cultural Resource Management Plan, which is the basis of the programmatic agreement among DOE-ID, the Idaho State Historic Preservation Office, and the Advisory Council on Historic Preservation, as well as an Agreement-in-Principle between DOE-ID and the Shoshone-Bannock Tribes.

\subsubsection{Prehistoric and Historic Archaeological Sites and Artifacts}

Efforts to inventory INL Site cultural resources are ongoing. These investigations have been completed in project-specific localities and areas identified within research designs. To date, approximately $10 \%$ of the $2,303 \mathrm{~km}^{2}\left(889 \mathrm{mi}^{2}\right)$ INL Site has been inventoried for archaeological sites, resulting in an inventory of nearly 3,000 resources. Archive and collections management for INL Site cultural resources is conducted on a variety of levels. Legal guidelines are followed to ensure preservation of these important materials in perpetuity for the benefit of the American people.

\subsubsection{National Historic Landmark Buildings}

Over 500 INL Site buildings have been surveyed and assessed for their eligibility to the National Register of Historic Places, and over nearly 300 were identified as historic and potentially eligible for nomination. Inventories of historic architectural properties at NRF have not been completed and efforts to inventory significant INL Site objects are ongoing. At present, the only INL Site properties formally listed as National Historic Landmarks are the EBR-I reactor and guardhouse. The EBR-I National Historic Landmark is open to the public daily from Memorial Day through Labor Day each year. It offers educational displays and guided tours on the INL's historic nuclear past and on nuclear power in general.

Aviators Cave, an important Native American resource and sensitive archaeological site, also has been listed. Many other archaeological resources on the INL Site are potentially eligible for nomination.

Fifteen other INL Site architectural properties have been designated as signature properties. Signature property is a term coined by DOE that denotes its most historically important properties across the complex or those properties that are viewed as having tourism potential. The 15 signature properties are as follows:

1. Materials Test Reactor (TRA-603) undergoing demolition

2. Manufacturing and Assembly Building (TAN-607) demolished

3. Nuclear Airplane Hanger (TAN-629)

4. Loss-of-Fluid Test Control Building (TAN-630) demolished

5. Loss-of-Fluid Test Dome (TAN-650) demolished

6. Marine Barracks (CFA-606)

7. Commanding Officer's House (CFA-607) 
8. Commanding Officer's Garage (CFA-632)

9. Officers' Quarters (CFA-613)

10. Proofing Area (CFA-633)

11. Central Facilities World War II Pumphouse (CFA-642)

12. Central Facilities World War II Pumphouse (CFA-651)

13. Chemical Processing Building (CPP-601) undergoing demolition

14. Heat Transfer Reactor Experiment (HTRE-2)

15. Heat Transfer Reactor Experiment (HTRE-3).

\subsection{Wildland Fires}

The hot, dry summers characteristic of eastern Idaho predispose sagebrush steppe communities to a history of recurring fire. Estimates of fire return intervals for sagebrush-steppe systems range from around 20 to over 100 years. ${ }^{40,41,42}$ It has been hypothesized that the natural interval between fires in these systems must be sufficiently long to allow big sagebrush, which does not resprout, to regain dominance through recolonization of burned sites from seed. Otherwise, these areas would become dominated by root-sprouting shrubs such as horsebrush or rabbitbrush. ${ }^{39}$

Numerous fire scars are evident in aerial photographs and satellite images of the INL Site. The scars of several fires that have burned during this century have been mapped from satellite imagery or aerial surveys. Wildfires have been aggressively controlled at the INL Site since 1950, which may have decreased the area that otherwise would have burned. One of the large fires occurred in 1994, starting near the junction of Highways 20 and 22 on the western boundary of the INL Site and extending a distance of almost $25 \mathrm{~km}$ (15.5 miles). Since the 1994 fire, the INL Site has seen a number of other large wildfires. In fact, approximately $25 \%$ of the INL Site has burned since that time. A 16,160-hectare (40,000-acre) fire $\left(164 \mathrm{~km}^{2}\right.$ or $\left.63 \mathrm{mi}^{2}\right)$ burned on the INL Site in 1999 and 2000. In 2010, two wildfires swept through INL Site lands, including the largest fire in INL Site history and another that burned near and over Middle Butte Cave. Driven by extremely high winds, the July 13, 2010, Jefferson Fire burned 32,053 hectares $(79,339$ acres) on the INL Site and 11,924 hectares (29,516 acres) off the INL Site. The August 27, 2010, Middle Butte Fire burned 5,255 hectares (13,008 acres) on the INL Site and 457 hectares (1,131 acres) off the INL Site. The 44,037 hectares (109,000 acres) Jefferson Fire that occurred in 2010 is the single largest blaze in INL Site history. Information on these and other fires can be found on the Environmental Surveillance, Education, and Research Program website. ${ }^{19}$ A map of the more recent large fire scars on the INL Site is illustrated in Figure 24.

Fires on the INL Site have heightened concerns because of the potential to burn through radiologically contaminated areas, posing a hazard to firefighters and the public. Exposure to windblown contaminated dust from fire-eroded landscapes is another concern.

The INL maintains an onsite fire department to provide wildfire management in cooperation with BLM and local municipalities. Restrictions are in place to minimize the potential for human-caused fires when the vegetation is most susceptible to fire. For more information about specific fire restrictions, refer to the INL Wildfire Management Guide. ${ }^{43}$

\subsection{Floodplain}

Floodplains are lowland and relatively flat areas adjoining inland and coastal waters. Federal agencies are required to avoid adverse impacts on floodplains and to their occupants. The need for developing riverine flood control at INL was first recognized in the 1950s when the ATR Complex and INTEC were threatened by flooding as a result of ice jams on the Big Lost River. 


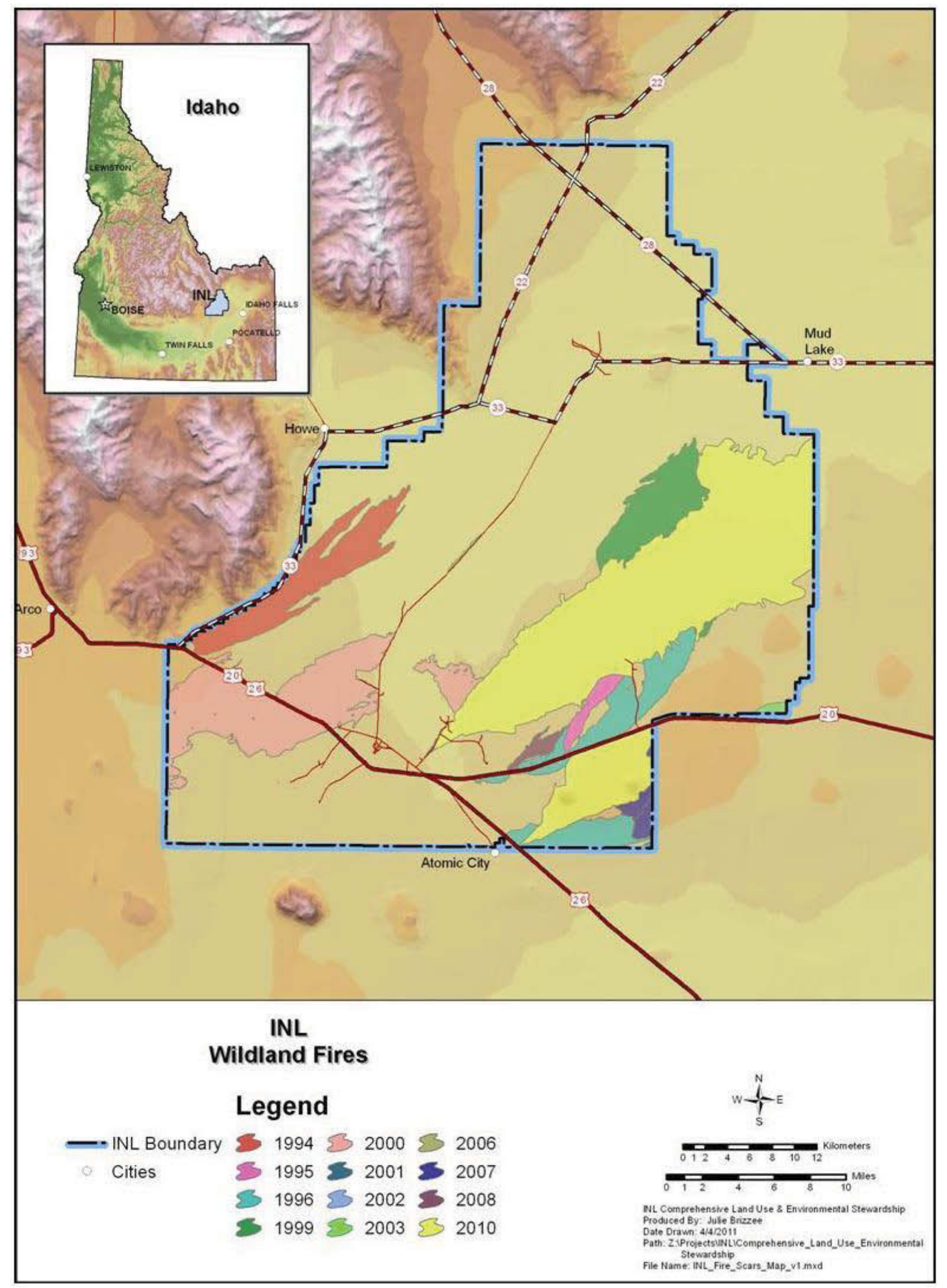

Figure 24. Idaho National Laboratory wildland fires. 
In 1958, the INL diversion system was constructed to divert high-runoff flows from the Big Lost River to protect downstream facilities. The diversion system consists of a diversion dam, two gated culverts, three dikes, four spreading areas, and two interconnecting channels. The dam and dikes were upgraded in the early 1980s to handle larger flow volumes. When flows exceed $377 \mathrm{ft}^{3} / \mathrm{s}$ at the diversion system headgate, which is approximately $3.22 \mathrm{~km}$ ( 2 miles) northwest of RWMC, some of the river will naturally flow into the diversion channel and into the RWMC spreading areas. The amount diverted can be regulated by the diversion dam headgates. Water diverted to the spreading areas either evaporates or infiltrates to the Eastern Snake River Plain Aquifer. The diversion channel is capable of carrying $7,200 \mathrm{ft}^{3} / \mathrm{s}$ from the river into the spreading areas. ${ }^{44}$ Two low swales located southwest of the main channel can carry an additional $2,100 \mathrm{ft}^{3} / \mathrm{s}$, producing a combined diversion capacity of $9,300 \mathrm{ft}^{3} / \mathrm{s}^{41}$ Water diverted to the spreading areas either evaporates or infiltrates to the aquifer. Water remaining in the Big Lost River channel continues to flow northeastwardly to the Big Lost River playas near TAN.

Riverine flooding also has occurred along Birch Creek near TAN as a result of ice jams. In 1969, because of concerns about the potential for flooding at TAN, INL constructed channels and began diverting the water to several gravel pits east of TAN. Most of the flows are lost to seepage in the lower portions of the valley before flowing onto the INL Site boundary. However, Birch Creek does flow onto the INL Site during high water years, and it can negatively impact several TAN facilities if not diverted, especially when there is severe icing in the channel.

\subsubsection{Big Lost River 100-Year Flood}

Several studies have calculated the potential magnitude of a 100-year flood for the Big Lost River at the Arco gauging station (a station $22.5 \mathrm{~km}$ [14 miles] upstream from the INL Site diversion dam). The first calculated value of the mean 100-year flood magnitude range from 3,700 to 7,200 $\mathrm{ft}^{3} / \mathrm{s}^{45,46,47,48}$ This range is attributed to the type of analysis, the data sets being used, the region of the river that was being analyzed, and other inherent assumptions used in the analysis. A study using paleohydrologic data collected from several stream reaches along the Big Lost River below the Arco station, in combination with historical stream gauge data from the Arco station, estimates a magnitude of 3,300 $\mathrm{ft}^{3} / \mathrm{s}$ for the 100-year flood for the Big Lost River at the Arco station. ${ }^{49}$ Subsequently, the U.S. Geological Survey revised their estimate to be $3,740 \mathrm{ft}^{3} / \mathrm{s}$ with a $95 \%$ uncertainty ranging from 1,395 to $6,250 \mathrm{ft}^{3} / \mathrm{s}$. Comments on topographic data ${ }^{45}$ prompted a revision to their previous estimate. After revisiting the basin topography, the newest estimate of the 100 -year flood magnitude is $3,070 \mathrm{ft}^{3} / \mathrm{s} .{ }^{50}$ Figure 25 illustrates the 100 -year floodplain on the INL Site using this magnitude and assuming that there is no infiltration, and an upstream diversion dam does not exist.

Flooding at the INL Site is further complicated by the construction of the INL Site diversion dam. This dam was built to control flow onto the INL Site, protecting the downstream facilities from flooding. Gates placed on two large, corrugated steel culverts control flow onto the INL Site and limit the flow of the Big Lost River to less than $900 \mathrm{ft}^{3} / \mathrm{s}$ downstream of the diversion dam. ${ }^{51}$ Although the INL Site diversion channel was designed to handle flows in excess of $7,200 \mathrm{ft}^{3} / \mathrm{s}^{41}$ a recent field investigation pertaining to the structural integrity of the INL Site diversion dam by the Army Corps of Engineers ${ }^{52}$ indicates the safe holding flowrate at the diversion dam is now thought to be about $7,300 \mathrm{ft}^{3} / \mathrm{s}$. The diversion dam control of the flow of the Big Lost River and mean value of the most recent estimate of the 100-year flood $\left(3,070 \mathrm{ft}^{3} / \mathrm{s}\right)$ on the Big Lost River suggest that the 100-year flood would be contained by the diversion dam, posing no flood threat to INL Site facilities.

\subsubsection{Big Lost River Floods with Return Periods Greater than 100 Years}

Ostenna et al. (1999) ${ }^{61}$ performed a Bayesian flood-frequency analysis that indicates peak flows on the Big Lost River with return periods of 500, 1,000, and 10,000 years are 4,000,4,400, and 5,300 $\mathrm{ft}^{3} / \mathrm{s}$, respectively. These results suggest that exceedance of the estimated maximum capacity of the INL Site diversion dam of $9,300 \mathrm{ft}^{3} / \mathrm{s}^{41}$ has an extrapolated annual exceedance probability smaller than 0.00001 (or 
greater than 100,000-year return period). Assuming a safeholding capacity of 5,000 $\mathrm{ft}^{3} / \mathrm{s}$ for the INL Site diversion dam, the annual exceedance probability is 0.0002 (or a 5,000-year return period).

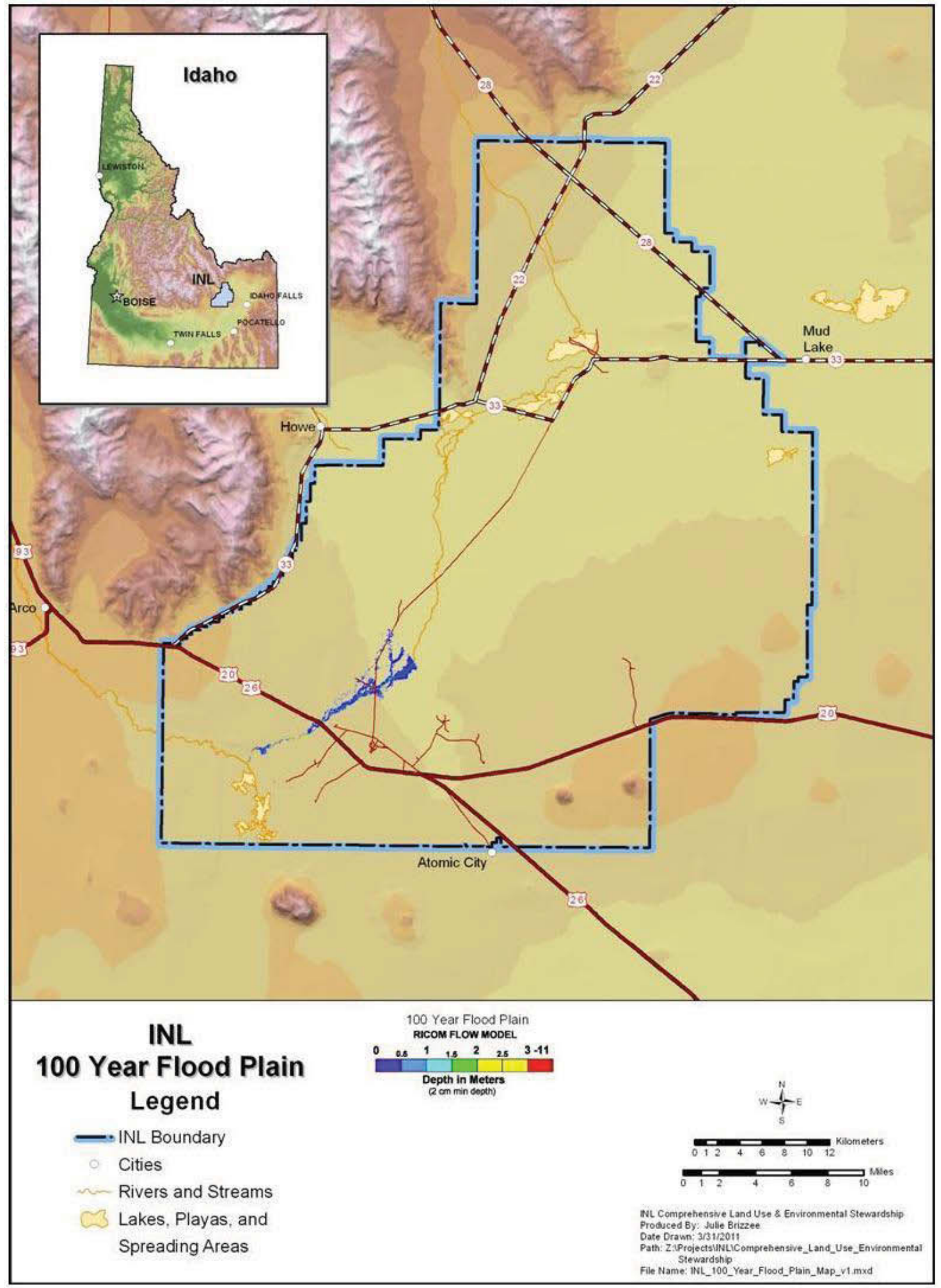

Figure 25. Big Lost River 100-year floodplain. 


\subsection{Seismicity}

The INL Site resides within the eastern Snake River Plain of Idaho near its juncture with the northern Basin and Range Province. The Eastern Snake River Plain is a 400-km (250-miles) long, 100-km (65 miles) wide, low-relief volcanic province flanked by mountain ranges of the Basin and Range Province and the northern Rocky Mountains. The Snake River Plain was formed by crustal subsidence, basaltic volcanism, and sedimentation after passage of the Yellowstone Hotspot beneath southern Idaho. The Yellowstone Hotspot, now residing beneath Yellowstone National Park, caused explosive caldera-forming eruptions 2 to 0.6 million years ago and currently energizes the existing geothermal features of the park. At about 10 to 4.3 million years ago, it passed beneath the Eastern Snake River Plain and produced caldera eruptions similar to those at Yellowstone. Since then, volcanism on the Eastern Snake River Plain has been characterized by effusive basaltic volcanism with the most recent basalt lava flows erupting approximately 2, 100 years ago.

INL has conducted geological investigations since the 1960s. INL continuously monitors seismic activities and these results are incorporated into seismic and volcanic hazards assessments. High-quality assessments of geologic hazards are attained through cooperative investigations and peer review by numerous knowledgeable scientists from the U.S. Geological Survey, the Nuclear Regulatory Commission, major universities, other national laboratories, seismic hazard consultants, earthquake engineering firms, and seismic experts coordinated by the State of Idaho. The results of these investigations are incorporated into the design criteria so that INL Site facilities can be built to withstand earthquakes and can be located in areas to minimize the effects from volcanism.

Figure 26 illustrates the surficial geologic characteristics of the INL Site. Additional information concerning these characteristics can be obtained at the INL Seismic Monitoring webpage. ${ }^{53}$ A project to update the INL seismic studies is currently ongoing. 


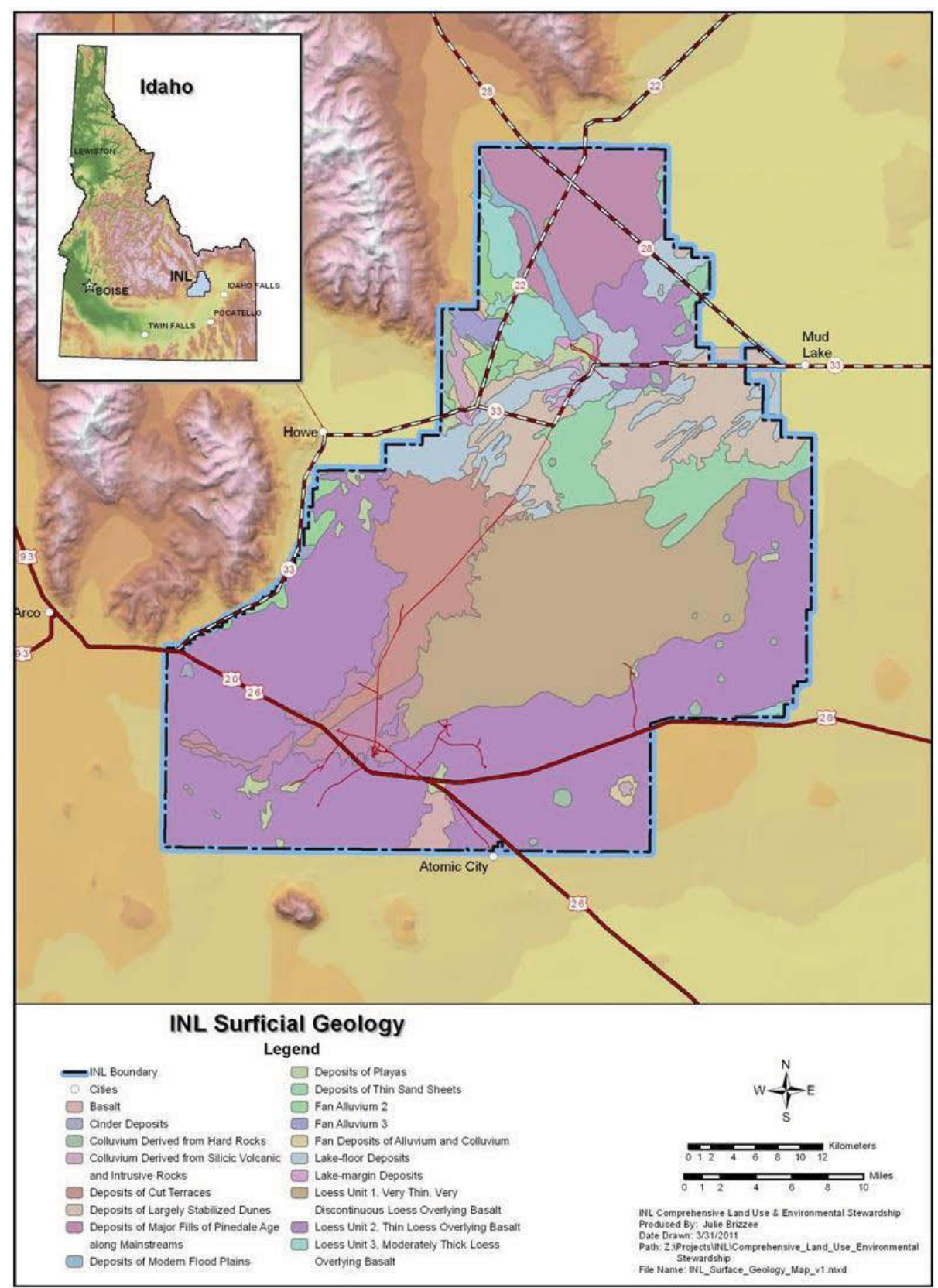

Figure 26. Idaho National Laboratory surficial geology.

\section{REFERENCES}

1. Idaho National Laboratory Ten-Year Site Plan for Fiscal Year 2012, DOE/ID-11427, Idaho National Laboratory, June 2010.

2. Nuclear Energy Research and Development Roadmap, Report to Congress, U.S. Department of Energy, April 2010.

3. "Facilities for the Future of Nuclear Energy Research: A Twenty-Year Outlook (Draft)," Department of Energy Office of Nuclear Energy, February 2009. 
4. INEEL Comprehensive Facilities and Land Use Plan, DOE/ID-10514, Idaho National Engineering and Environmental Laboratory, March 1996.

5. S. Stacy, Proving the Principle-A History of the Idaho National Engineering and Environmental Laboratory 1949-1999, DOE/ID-10799, Jason Associates Corporation, Idaho Falls, Idaho, 2000.

6. Idaho National Engineering and Environmental Laboratory Cultural Resource Management Plan, DOE/ID-10997, Idaho National Engineering and Environmental Laboratory, Idaho Falls, Idaho, August 2004.

7. “INL’s 52 Nuclear Reactors,” Idaho National Laboratory, http://nuclear.inl.gov, 2011.

8. Idaho National Laboratory Site-Wide Institutional Controls, and Operations and Maintenance Plan for CERCLA Response Actions, DOE-ID/11042, Revision 6, July 2010.

9. Idaho National Laboratory Institutional Control Sites Database, https://cleanup.icp.doe.gov/ics.

10. Census Bureau, State and County Quick Facts. http://quickfacts.census.gov/qfd/index.html, 2011.

11. U.S. Department of Agriculture, 2007 Census of Agriculture, County Profile, http://www.agcensus.usda.gov/Publications/2007/Online Highlights/County_Profiles/Idaho/cp16051. pdf.

12. U.S. Department of Agriculture, 2007 Census of Agriculture, County Profile, http://www.agcensus.usda.gov/Publications/2007/Online_Highlights/County_Profiles/Idaho/cp16051. pdf.

13. Environmental Assessment for the Multipurpose Haul Road Within the Idaho National Laboratory Site, DOE/EA-1772, U.S. Department of Energy.

14. INEEL Sagebrush Steppe Ecosystem Reserve Final Management Plan, EA-ID-07402-067, Bureau of Land Management, Idaho Falls, Idaho, May 2004.

15. K. L. Pierce and L. A. Morgan, 'The Track of the Yellowstone Hot Spot: Volcanism, Faulting, and Uplift," Regional Geology of Eastern Idaho and Western Wyoming, P. K. Link, M. A. Kuntz, and L. B. Platt. Boulder, Colorado, The Geological Society of America: 1-53.

16. W. R. Hackett and R. P. Smith, "Quaternary volcanism tectonics, and sedimentation in the Idaho National Engineering Laboratory Area," Field guide to geologic excursions in Utah and adjacent areas of Nevada, Idaho, and Wyoming, J. R. Wilson, Salt Lake City, Utah, Utah Geological Survey, Miscellaneous Publication 92-3: 1-18.

17. P. K. Link and E. C. Phoenix, Rocks, Rails and Trails, Idaho State University Press, Pocatello, Idaho, 1994.

18. M. A. Kuntz, B. Skipp, M. A. Lanphere, W. E. Scott, K. L. Pierce, G. B. Dalrymple, D. E. Champion, G. F. Embree, W. R. Page, L. A. Morgan, R. P. Smith, W. R. Hackett, and D. W. Rodgers, Geologic map of the INEL and adjoining areas, eastern Idaho, U.S. Geological Survey, 1994, Miscellaneous Investigation Series Map I-2330.

19. INL Environmental Surveillance, Education and Research Program, S.M. Stoller Corporation, www.stoller-eser.com, 2005.

20. G. L. Olson, D. J. Jeppesen, and R. D. Lee, The Status of Soil Mapping for the Idaho National Engineering Laboratory, INEEL/EXT-95-00960, Lockheed Idaho Technologies Company, Idaho Falls, Idaho, 1995. 
21. W. G. Graham and L. J. Campbell, Groundwater Resources of Idaho: unpublished report by the Idaho Department of Water Resources, 1981.

22. 40 CFR 230.3(t), "Definitions," Code of Federal Regulations, Office of Federal Register, August 1993.

23. U.S. Code, Title 33, Chapter 26, Subchapter 1251, Congressional Declaration of goals and policies, "Clean Water Act," 2002.

24. N. L. Hampton, R. C. Rope, J. M. Glennon, and K. S. Moor, A Preliminary Survey of National Wetland Inventory as Mapped for the Idaho National Engineering Laboratory, INEL-95/0101, Lockheed Idaho Technologies Company, Idaho Falls, Idaho, March 1995.

25. Water Rights Agreement Between the State of Idaho and the United States, for the United States Department of Energy, U.S. Department of Justice, Environmental and Natural Resources Division, Washington DC, July, 1990.

26. 40 CFR 149, "Sole-Source Aquifer Program," Code of Federal Regulations, Office of Federal Register, August 2005.

27. Stoller, Current and Past Research at the Idaho NERP, 2011, http://www.stoller-eser.com/research.htm.

28. M. L. Shumar and J. E. Anderson, "Gradient Analysis of Vegetation Dominated by Two Subspecies of Big Sagebrush," Journal of Range Management, 39, 1986, pp. 156-160.

29. Idaho's Endangered, Threatened, Proposed, and Candidate Species (With Associated Proposed and Critical Habitats) Under the Jurisdiction of the Fish and Wildlife Service (updated December 13, 2010) http://www.fws.gov/idaho/species/IdahoSpeciesList.pdf.

30. Idaho Department of Fish and Game, Idaho Conservation Data Center, 2011, http://www.fishandgame.idaho.gov/cdc.

31. Stoller, Vertebrates of the INL, Summary, 2011, http://www.stoller-eser.com/LandManagement/species_summary.htm.

32. T. D. Reynolds, J. W. Connelly, D. K. Halford and W. J. Arthur, "Vertebrate Fauna of the Idaho National Environmental Research Park," Great Basin Nature, 46, 1986, pp. 513-527.

33. Pronghorn Winter Range, U.S. Department of Energy, Idaho Falls, Idaho, 1997.

34. K. L. Cieminski, Wildlife Use of Wastewater Ponds at the Idaho National Engineering Laboratory, South Dakota State University, Brookings, South Dakota, 1993.

35. W. H. Clark and P. E. Blom, "Observations on the Relationship Between Ants (Hymenoptera: Formicidae: Myrmicinae, Dorylinae) and Araeoschizus (Coleoptera: Tenebrionidae)," Journal of the Idaho Academy of Science, 24 (1/2), 1988, pp. 34-37.

36. W. H. Clark W. H. and P. E. Blom, "Notes on Spider (Theridiidae, Salticidae) Predation of the Harvester Ant, Pogonomyrmex salinus Olsen (Hymenoptera: Formicidae: Myrmicinae), and a Possible Parasitoid Fly (Chloropidae)," Great Basin Naturalist, 52 (4), 1992, pp. 385-386.

37. Idaho National Laboratory Cultural Resource Monitoring Report for FY 2010, INL Cultural Resource Management Office, INL/EXT-10-20270, October 2010

38. National Historic Preservation Act of 1966, 1966.

39. U.S. Department of Energy Idaho Operations Office, Cultural Resource Management Plan, 2009. 
40. D. B. Houston, "Wildfires in Northern Yellowstone Park," Ecology, 54, 1973, pp. 1111-1117.

41. H. A. Wright and A. W. Bailey, Fire Ecology: United States and southern Canada, John Wiley and Sons, New York, New York, 1982.

42. H. A. Wright, L. F. Neuenschwander, and C. M. Britton, The Role and Use of Fire in Sagebrushgrass and Pinyon-juniper Plant Communities: a State-of-the-Art Review, USDA Forest Service, General Technical Report INT-58, Intermountain Forest and Range Experiment Station, Ogden, Utah, 1979.

43. "INEEL Wildland Fire Management Guide," GDE-7063, Idaho National Engineering and Environmental Laboratory, Idaho Falls, Idaho, July 10, 2002.

44. C. M.Bennett, Capacity of the Diversion Channel Below the Flood-Control Dam on the Big Lost River at the Idaho National Engineering Laboratory, Report 86-4204, U.S. Geological Survey, Idaho Falls, ID, October 1986.

45. J. A. Tullis and K. N. Koslow, Characterization of Big Lost River Floods with Recurrence Intervals Greater Than 25 Years, RE-PB-83-044, EG\&G Idaho, Inc., Idaho Falls, Idaho, 1983.

46. U.S. Army Corps of Engineers, Feasibility Report, Big Lost River Basin, Idaho, Walla Walla, Washington, 1991.

47. M. A. J. Stone, L. J. Mann, and L. C. Kjelstrom, Statistical Summaries of Streamflow Data for Selected Gaging Stations on or Near the Idaho National Engineering Laboratory, Idaho, Through September 1990, DOE/ID-22109, Water Resources Investigations Report 92-4196, U.S. Geological Survey, Idaho Falls, Idaho, 1992.

48. J. E. Hortness and J. P. Rousseau, Estimating the Magnitude of the 100-Year Peak Flow in the Big Lost River at the Idaho National Engineering and Environmental Laboratory, Idaho, Water Resources Investigations Report 02-4299, Idaho Falls, Idaho, 2002.

49. D. A. Ostenna, D. R. Levish, and R. E. Klinger, Phase 2 Paleohydrologic and Geomorphic Studies for the Assessment of Flood Risk for the Idaho National Engineering and Environmental Laboratory, Idaho, Report 99-7, Geophysics, Paleohydrology, and Seismotectonics Group, Technical Service Center, Bureau of Reclamation, Denver Colorado, 1999.

50. U.S. Department of the Interior, Big Lost River Flood Hazard Study Idaho National Laboratory, prepared for the Idaho National Laboratory by the Bureau of Reclamation, Denver, Colorado, 2005.

51. R. D. Lamke, Stage-Discharge Relations on the Big Lost River Within National Reactor Testing Station, Idaho, Water Resources Division, IDO-22050, U.S. Geological Survey, Idaho Falls, Idaho, 1969.

52. R. M. Berger, "Draft Plan of Study Big Lost River Diversion Dam and Facilities," U.S. Army Corps of Engineers Draft memo, Walla Walla District, June 17, 1997.

53. INL's Seismic Monitoring Webpage, Idaho National Laboratory, 2011, https://inlportal.inl.gov/portal/server.pt/community/inl_seismic_monitoring_program/441/ inl_seismic_monitoring_program_main_page/4362,2011. 